\title{
Digital Fabrication in the Production of Affordable Housing
}

\author{
By \\ James Hayes, B.Sc. Arch \\ A Thesis submitted to \\ the Faculty of Graduate Studies and Research \\ in partial fulfillment of the requirements for the degree of \\ Master of Architecture
}

School of Architecture

Carleton University

Ottawa, Ontario

September 2005

(C)2005, James Hayes 


\section{Abstract}

The way in which architects communicate construction information has been shaped by societal and technological changes over the past 150 years. A more litigious and economically motivated society and the mass production of standardized building materials have left the architect in a position of lesser power and therefore with a reduced social mandate. Social responsibility in housing is in greater need as governments have ceased to be providers of affordable housing. The emerging technology of computer numerical controlled (CNC) fabrication facilitates a new mode of practice for architects that allows for greater engagement in the process of construction. Detroit, a city whose development is deeply connected to mass production, is seen as a fitting and ironic site to explore the architectural potential of a housing project utilizing CNC fabrication. In an urban, yet strangely rural landscape, this project seeks a diverse and organic model different from current affordable housing schemes and the universal, utopian modernist projects. 


\section{Acknowledgments}

I wish to thank Professor Stephen Fai, my thesis advisor, for his guidance throughout the year long process of writing this thesis. I wish to thank my wife Melissa for her support, patience, and love over the course of my time at Carleton, without which I could not have completed my thesis. And thank you to my parents who provided me with the necessary support throughout my school years prior to coming to Carleton. 


\section{Table of Contents}

Introduction

1 Housing 4

1.1 Public Housing to Affordable Housing 4

1.2 Housing in Detroit 9

1.3 The Architect's Role in Housing $\quad 14$

$\begin{array}{lll}2 & \text { Standardization } & 18\end{array}$

$\begin{array}{ll}2.1 & \text { From Craft to Mechanization } \\ \end{array}$

2.2 Modernism's Embrace of Mass Production, Standardization 22

2.3 Standardization in Contemporary Construction 28

$3 \quad$ Building $\quad 33$

3.1 Drawing for Construction 33

3.2 CNC Digital Fabrication in Architecture 38

3.3 Digital Master Builder Concept 43

$\begin{array}{llr}4 & \text { Precedents } & 48\end{array}$

4.1 Frank O. Gehry/A Architects 48

4.2 William Massie $\quad 54$

5 Design Proposition $\quad 58$

$\begin{array}{lll}5.1 & \text { Context } & 58\end{array}$

5.2 Design 63

$\begin{array}{lr}\text { Conclusion } & 86\end{array}$

$\begin{array}{lr}\text { Works Cited } & 90\end{array}$ 


\section{List of Tables}

Table 1. 2000 Census Profile for Jefferson/Mack Subsector, Source: U.S. Census Bureau; 2000 Census; Summary File 3 


\section{List of Illustrations}

Fig. 1. The central office towers of Le Corbusier's Ville Contemporaine with its transport interchange, The Experience of Modernism: Modern Architects and the Future City 1928-1953 (London, 1997)

Fig. 2. The failed Pruitt-Igoe housing project in Saint Louis, Missouri 1956, From Tenements to the Taylor Homes: In Search of an Urban Housing Policy in TwentiethCentury America (Pennsylvania, 2000) 182.

Fig. 3. Single-family detached homes made Detroit a low-rise city, The Origins of the Urban Crisis: Race and Inequality in Postwar Detroit (Princeton, 1996) 21.

Fig. 4. Ford Motor Company's River Rouge Factory, 1930, From the American System to Mass Production 1800-1932 (Baltimore, 1984) 269.

Fig. 5. Ford V-8 engine assembly, River Rouge Factory, 1930s, From the American System to Mass Production 1800-1932 (Baltimore, 1984) 299.

Fig. 6. The output of a single day of Ford Model T's, Highland park Factory, 1915, From the American System to Mass Production 1800-1932 (Baltimore, 1984) 2.

Fig. 7. Prefabricated house for General Panel, The Dream of the Factory Made House (Cambridge, 1984) 261

Fig. 8. Plasma-arc CNC cutting of steel supports, Architecture in the Digital Age: Design and Manufacturing (New York, 2003) 34

Fig. 9. Three axes and five axes mills, Architecture in the Digital Age: Design and Manufacturing (New York, 2003) 34.

Fig. 10. Contouring of rigid foam for pre-cast concrete panels, Architecture in the Digital Age: Design and Manufacturing (New York, 2003) 36.

Fig. 11. Walt Disney Concert Hall photo and digital model, Architecture in the Digital Age: Design and Manufacturing (New York, 2003) 118.

Fig. 12. Walt Disney Concert Hall digital coordination model, Architecture in the Digital Age: Design and Manufacturing (New York, 2003) 114.

Fig. 13. Final design model for EMP, Gehry Talks: Architecture + Process (New York, 2002) 201. 
Fig. 14. Walt Disney Concert Hall, Architecture in the Digital Age: Design and Manufacturing (New York, 2003) 103.

Fig. 15. Puzzle piece with joints lasercut in steel - holes are cut to admit pvc piping, Praxis: Journal of Writing + Building 6 (2004) 18.

Fig. 16. Puzzle piece joint details, top Playa Urbana, bottom Big Belt House, Praxis: Journal of Writing + Building 6 (2004) 19.

Fig. 17. The strangely rural landscape of eastside Detroit.

Fig. 18. Collapsed house.

Fig. 19. Opposite sides of Mack Ave, left Detroit, right Grosse Pointe Park.

Fig. 20. Aerial composite.

Fig. 21. Aerial perspective of site prior to construction of Morningside Commons.

Fig. 22. Morningside Commons detached houses.

Fig. 23. Morningside Commons semi-detached townhouses.

Fig. 24. Typical "bungalow style" houses on the eastside of Detroit.

Fig. 25. Typical "bungalow style" houses in Grosse Pointe Park.

Fig. 26. Site plan showing new lots (orange), vacant lots (green) wheat, and community gardens.

Fig. 27. Perspective plan.

Fig. 28. Perspective section.

Fig. 29. Perspective section.

Fig. 30. Interior perspective.

Fig. 31. Assembly detail.

Fig. 32. Construction stage 1 .

Fig. 33. Construction stage 2.

Fig. 34. Construction stage 3 .

Fig. 35. Construction stage 4 . 
Fig. 36. Construction stage 5.

Fig. 37. Assembly detail.

Fig. 38. Exterior perspectives.

Fig. 39. Figure-ground plan with proposed houses.

Fig. 40. Contoured rigid insulation.

Fig. 41. Contoured rigid insulation.

Fig. 42. Digital model of "wall".

Fig. 43. Plan of "wall".

Fig. 44. Three-axis $\mathrm{CNC}$ router.

Fig. 45. Three-axis CNC router cutting plywood.

Fig. 46. Leftover plywood.

Fig. 47. Assembled "wall". 


\section{Introduction}

Fundamental to the practice of architecture is the method used by architects to communicate and describe the design of a building to the group of people who perform the actual construction. The evolution of this method has been ongoing for thousands of years, but contemporary practice has been most affected by the past 150 years or so. During this time period societal change and technological change have affected the way architects communicate construction information. Most contemporary practices explicitly describe the design of buildings through two-dimensional working drawings and specifications which are completed before construction begins. This method of explicit description developed throughout the nineteenth century. A more litigious and economically motivated society dictated the production of detailed drawings and specifications as part of the construction contract between contactor and client. For the same legal reasons the roles of designer and constructor were formalized by professional associations and schools.

Technological change during the nineteenth and early twentieth century in the form of mechanization altered the workforce at large and the craftsmen on construction sites. Skilled labour was replaced by unskilled labour through mechanization as a means of cost reduction. This led to a deskilling of the workforce. On the construction site, detailed drawings and specifications also led to deskilling of building craftsmen.

Standardized building materials produced in mechanized factories also contributed this deskilling.

The time period around the turn of the twentieth century saw fundamental changes to the North American urban landscape. Cities continued to expand rapidly, as 
mechanized industry flourished and required a large unskilled work force. The population of the United States was in turn becoming more urban. In Detroit, Henry Ford had unleashed the idea of mass production upon the world. The ethos of mass production influenced more than just the automobile industry as more and more consumer goods were being mass produced. On the architectural front the Modern Movement was formulating its assault on the styles of the previous century. Modern architects, specifically Le Corbusier and Walter Gropius were also arguing for a socially responsible architecture of mass housing for disadvantaged urban residents. This revolution was to be achieved through standardization of construction, the same way that standardization was necessary for the mass production methods of the automobile industry.

After World War II, the United States government funded the construction of illfated housing projects and urban redevelopment schemes based on concepts put forth by the Modern Movement. High-rise apartment buildings envisioned to be bright and airy were, when physically realized, gloomy imposing tower blocks. The high-rise housing projects were used to house displaced residents of slum clearance projects that were excuses to build freeways and infrastructure for the automobile. Government-funded public housing came to an end when in an economic era of fiscal restraint in the1970s, government-funded public housing gave way to privatized affordable housing. (Bauman et al. 159)

In the 1960s American cities and industry began decentralizing. Detroit felt the brunt of this trend more than any other city. The city's population plummeted, and most residential neighbourhoods were completely decimated as half the residents moved to the 
suburbs. The remaining residents of Detroit, mostly poor African-Americans, are still in need of dignified affordable housing.

The notions of universal architecture and standardized construction promoted by the Modern Movement dramatically influenced the twentieth century. The lingering effects are a system in which architects are influenced more by contractors and building systems than the other way around. The shift to privatized affordable housing combined with all of these factors has contributed to architects no longer being in a position to influence affordable housing production.

The way architects communicate design information continues to evolve. Emerging digital technologies have revolutionized the way construction information is "described" by sending it directly to computer numerical control (CNC) machines for manufacture of building components. In this new mode of designing and constructing, the architect must take on a more active role in detailing. The notion of the architect as "digital master builder" provides the potential for architects not only to create extraordinary designs but also to become more engaged in the process of realizing the built work. In Detroit, the cradle of mass production, there is still a demand and urgent need for well designed and ethical housing for the urban poor. With this technology and a more influential mode of practice, it is hoped the social mandate of architects can be restored through the design of an affordable housing development. 


\section{Housing}

\subsection{Public Housing to Affordable Housing}

Modern architects in the early twentieth century sought to provide dignified housing for the urban poor and emancipate them from the deplorable living conditions of industrialized cities. Pollution and crowded slums were the norm for working-class citizens of cities of the time. The modernists advocated razing huge swaths of slums and building anew with universal, standardized architecture and urban design. In reaction to dark, cramped tenements, they proposed, among other models, massive residential tower blocks placed in open-air park settings so that all residents would have ample clean air and sunlight. Cities were to be redesigned with rational plans, and their functions, housing, industry, and transportation were to be segregated into zones bringing order to what they saw as the jumbled mess of the industrial city. Broad boulevards and expressways would allow unfettered access into cities for a newly mobile population in their automobiles. Le Corbusier's Ville Contemporaine and Ville Radieuse were emblematic projects illustrating the tenets of modern urban planning (Fig.1). To propagate their theories on architecture and the city, modern architects formed the Congres Internationaux d'Architecture Moderne or CIAM. From the late 1920s through to the '40s CIAM delineated their ideas on cities and urban planning through a series of congresses and publications that became influential for future city planning (Gold 60-62).

After World War II the government of the United States and American architects used the modernist models developed by the CIAM for Europe, to apply to public housing projects in the United States. Most large American cities engaged in post-war 


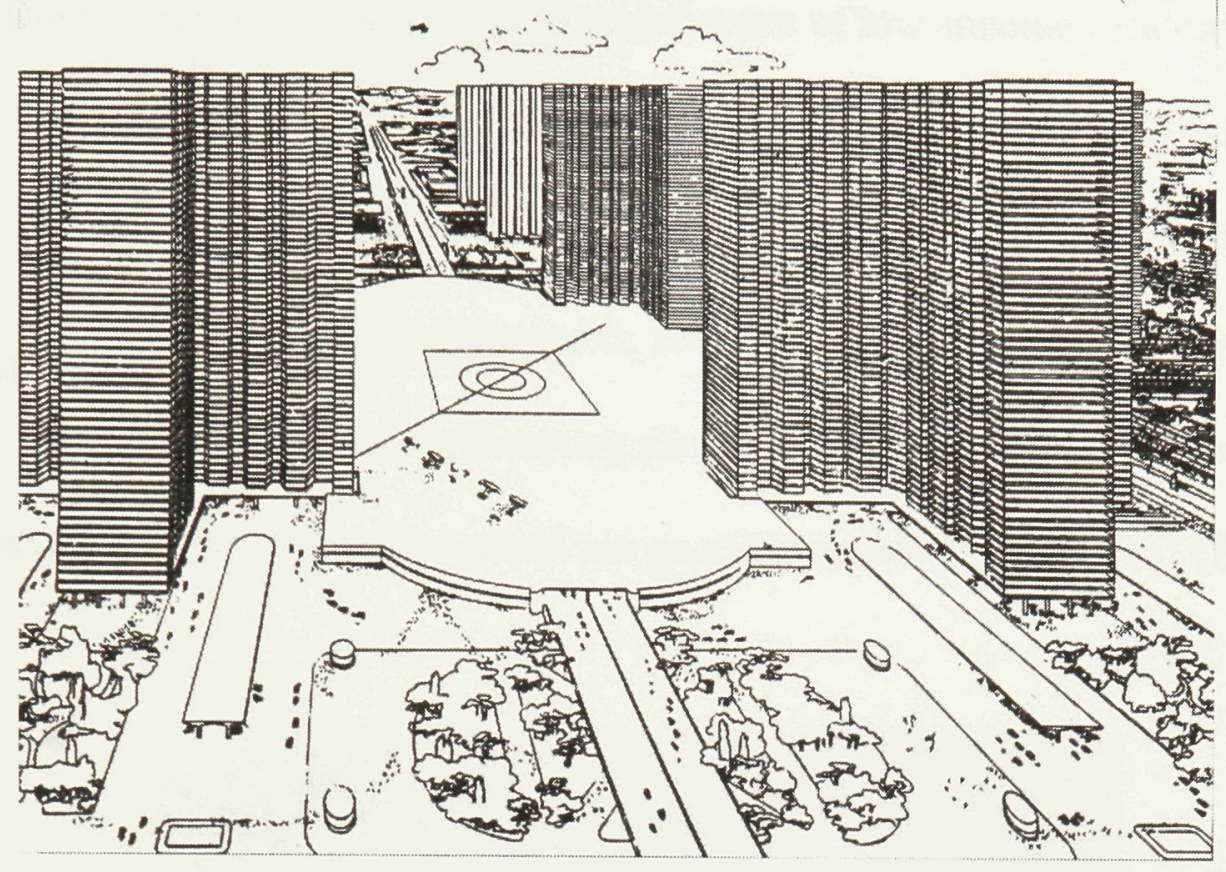

Fig. 1. The central office towers of Le Corbusier's Ville Contemporaine with its transport interchange, The Experience of Modernism: Modern Architects and the Future City 1928-1953 (London, 1997)

urban redevelopment projects consisting of demolishing entire slum areas and massive infrastructure projects that routed expressways through old neighbourhoods, displacing the former residents. Public housing for the displaced residents came in the form of highrise blocks in open parks, segregated from the rest of the city. "Impressed by the towerin-the-park design propounded by Swiss architect Le Corbusier, housing reformers and architects in the United States enthusiastically endorsed the high rise project as an innovative solution to the dearth of open space, the prohibitive cost of the land, and rapid rise or urban construction costs after World War II" (Bauman et al. 148). This model quickly became problematic. Tight budgets dictated, and instead of bright, airy apartments in lushly landscaped parks, residents lived in "grey fortresses that loomed menacingly over the cityscape" (Bauman et al. 153). Public housing was racially segregated, which meant a population of homogenous race and class were warehoused 
together. The projects concentrated large populations of low-income residents making economic advancement difficult. "[...] families remained indefinitely, children spent all their formative years in the projects, and intergenerational public housing families became commonplace. To many Americans, residents and onlookers alike, public housing had metamorphosed into a dumping ground for society's unfortunates and an absolute last resort for anyone who could not possibly do better elsewhere" (Bauman et al. 152).

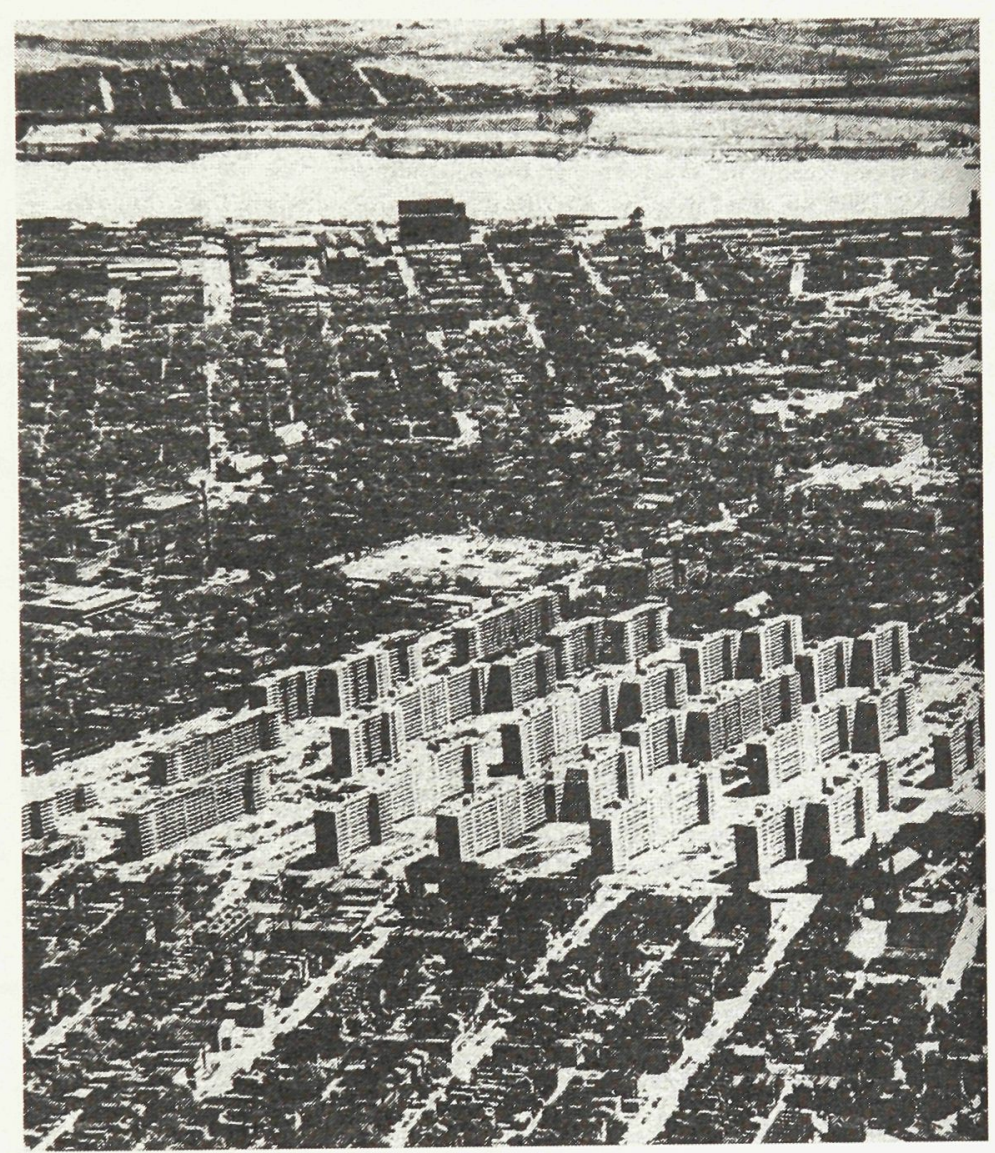

Fig. 2. The failed Pruitt-Igoe housing project in Saint Louis, Missouri 1956, From Tenements to the Taylor Homes: In Search of an Urban Housing Policy in Twentieth-Century America (Pennsylvania, 2000) 182.

The unofficial death knell for the large scale slum clearance and high-rise housing redevelopment was the implosion of Minoru Yamasaki's Pruit-Igoe in 1972. Pruit-Igoe 
was a public housing development of high rise apartment towers in St. Louis (Fig.2). "Only a few years after it was completed in 1956, disrepair, vandalism, and crime plagued Pruitt-Igoe" (Bauman et al. 180). It was deplored by residents and architectural critics alike. The project was seen as the embodiment of all the problems of public housing in the United States. The powerful symbolism conveyed by the imposing towers of Pruitt-Igoe of all that was wrong with public housing, ended with an equally symbolic demise. "In 1972, after spending over five million dollars in vain to cure the problems at Pruitt-Igoe, the Saint Louis housing Authority demolished [...] the high-rise buildings" (Bauman et al. 180). The implosion of the high rise project signified a coming shift in the way federal government would build public housing.

Beginning in the 1970s, the government acting with renewed economic restraint ceased to act as the primary developer of public housing, instead shifting the responsibility over to private developers. Public or social housing provided by the government became affordable or low-income housing provided by private developers. Although a subtle change in terminology, it was a consequential change in policy. After years of failure of the massive urban redevelopment projects, the government began retreating from providing public housing beginning with the Nixon Administration. "In January 1973, saying that 'this high cost no result boondoggling by the Federal Government must end', and touting rent subsidies as the best means of disassociating government from the construction and operation of housing, President Nixon declared a moratorium on all housing activities involving federal subsidies" (Bauman et al. 159).

During the Carter administration, HUD, the Department of Housing and Urban Development created Section 8, a program intended to spur private developers into 
building housing for people of low-income. Section 8 gave government money to landlords to make up the difference between market rents and what renters could afford to pay. "Under Section 8, HUD invited Local Housing Authorities (LHAs) to ask for a number of new or existing units to be supplied by the private sector. In fact, Section 8 played a major ideological role in shifting responsibility for low-income housing to the private sector" (Bauman et al. 253). The premise of Section 8 seemed like a remedy to the mega projects previously built and operated by the government. Local Housing Authorities that were attuned to local problems would be able to deal with issues better than the previous top-down approach. However, with further declines in government funding during the Reagan Administration, there was little money to give to the private sector.

Reagan cut Carter's 1981 budget request for $\$ 30$ billion in Section 8 housing certificates nearly in half. By 1985, Reagan had gutted the department of Housing and Urban Development budget by two-thirds. In the 1983 Urban Rural Renewal Act, Reagan terminated both Section 8 new construction and substantial rehabilitation programs leaving local housing authorities with a downscaled Section 8 and aging housing projects where refrigerators failed, gas lines still leaked, and vermin reigned. In the late 1980s and early 1990s 'vouchers', 'tenant ownership' and 'privatization' ... held sway at the Department of Housing and Urban Development. (Bauman et al. 261)

The government wanted to wash its hands of the failed high-rise projects, but the impetus for the change is the belief that privatization of home building would result in more cost-effective projects. Developers are thought to have a better understanding of market forces and demand for house types. The pervasive idea of family, especially for developers, is the nuclear family consisting of two parents. "[...] the so-called typical family, or those who would agree to have a house of a typical family, even if it does not exactly meet their needs" (Davis 76). Statistics show that large portions of the population 
are made up of other non-traditional families or households. Households can be made up of a single person, or two equal non-romantic partners, single-parent families, or a parent living with an adult child. In areas of lower income, instances of non-traditional households tend to increase, especially single-parent families that are often the majority. Developers continue to build homes for traditional nuclear families and households led by two working parents, because these groups make up a higher percentage of the market. These families purchase large suburban homes out of the price range of low-income families. Building known "best sellers" rather than smaller more affordable models limits the risk of slow sales upon construction completion. The many families and individuals who require affordable housing, but do not fall into these categories, are therefore overlooked as they simply cannot afford developer-built homes.

Risk aversion dictates many aspects of developer-built homes, including the neglect of smaller market shares like non-traditional families. Building houses in rundown or impoverished neighbourhoods does not guarantee sales, and innovative designs rarely take form for the same reason. "Since developers want to reduce their financial risk or the perception of risk, the market is continuously and subtly redefined to exclude the atypical" (Davis 76). The less risk a project is perceived to have, the more likely developers are to obtain financing from lenders and investors. There is little incentive to do anything different from what is known to work.

\subsection{Housing in Detroit}

The migration of African-American to urban centres in the Northeast and Midwest United States, beginning in 1910s was a significant shift in American 
demographics and marked the beginning of the urbanization of African-Americans. "The Great Migration" of African-Americans was spurred by industry in cities like, Detroit, Chicago, New York, Buffalo, and St. Louis that sought a large unskilled labour force (Sugrue 23). African-Americans of the rural southern United States were looking for economic opportunity and property ownership, both scarce in the south. "Migrants came with the hope that the booming northern city would be free of the harsh segregation that had perpetuated Jim Crow on the docks, in the mines, and in the warehouses of the South." (Sugrue 23) The migration peaked between 1940 and 1950, but continued into the 1970s. In the same industrial cities, Detroit especially so, deindustrialization and decentralization were rapidly changing the economic landscape of the post-Second World War city. After the war, lower taxes, lower wages, and government incentives sent factories bolting to suburban and rural locations in other parts of the country. "The forces of capital mobility reshaped the landscape of industrial America. New factories appeared on rural hillsides, in former cornfields and in cleared forests, and the shells of old manufacturing buildings loomed over towns and cities that were depopulated when business relocated production in more profitable places" (Sugrue 127). Unfortunately for the newly arriving African-Americans, little chance for home ownership was found, as well as dwindling opportunities for employment. Instead they found rental units owned by slum lords who continually cut up and sectioned apartments into smaller and smaller units as more African-Americans continued to arrive in the city. In Detroit government policy and private interests confined African-Americans to small, cramped slums like the ironically named "Paradise Valley" (Sugrue 24). 
If high rents were unable to keep African-Americans confined to the slums, there were racial zoning ordinances. "Numerous cities legitimized private racial animus with zoning ordinances which restricted city blocks according to the occupant's race" (Kushner 16). These ordinances were struck down by the Supreme Court after they were found to be unconstitutional in 1917, but they created the foundations for urban segregated living patterns, which were then reinforced by racially restrictive covenants. "Essentially, the covenant was a contract between landowners, prohibiting blacks from occupying the property" (Kushner 16). Restrictive covenants were incorporated into the deeds of not only individual plots of lands but also entire subdivisions. Racially restrictive covenants were eventually deemed illegal, but other less overtly racist covenants came into use. "Covenants that banned the taking of boarders or the division of homes into apartments effectively kept away the majority of blacks who could not afford to rent or buy a whole house" (Sugrue 45). Beginning in 1930s lenders and brokers used maps created by government officials to determine eligibility for mortgages and home loans. The maps ranked zones of Detroit from least to most eligible for home financing. "Most important in determining a neighborhood's classification was the level of racial, ethnic and economic homogeneity, the absence or presence of a 'lower grade population'. Every Detroit neighborhood with even a tiny African American population was rated "D" or "hazardous" by federal appraisers, and colored red on HOLC Security Maps" (Sugrue 44). This practice became known as redlining. Any neighborhood redlined by federal appraisers rarely qualified for federal home loans, and financing for builders wishing to build in these areas was equally as scarce. 
The confinement of blacks to slums was perpetuated by a post-war housing shortage and unique to Detroit, there was little public housing constructed after the war. When New York, Chicago and St. Louis cleared slums and built expressways, public housing projects were built for the displaced residents. White homeowners aiming to protect the investment of their newly purchased homes opposed any public housing, especially outside existing slums (Fig. 3). Detroit mayor Albert Cobo was elected in 1949 on the basis of his stance against public housing. "Cobo wasted no time fulfilling his anti-public housing promises. In his first weeks of office, he vetoed eight of the twelve proposed public housing sites, all but one in outlying, predominantly white sections of the city. By putting brakes on all public housing development outside of heavily black inner-city neighborhoods, Cobo finally killed public housing as a controversial political issue" (Sugrue 85). African-Americans were already shut out of the private housing market, and then denied public housing. Housing after World War II was such a volatile issue that Thomas Sugrue in The Origins of the Urban Crisis called it "Detroit's Time Bomb" (33). 


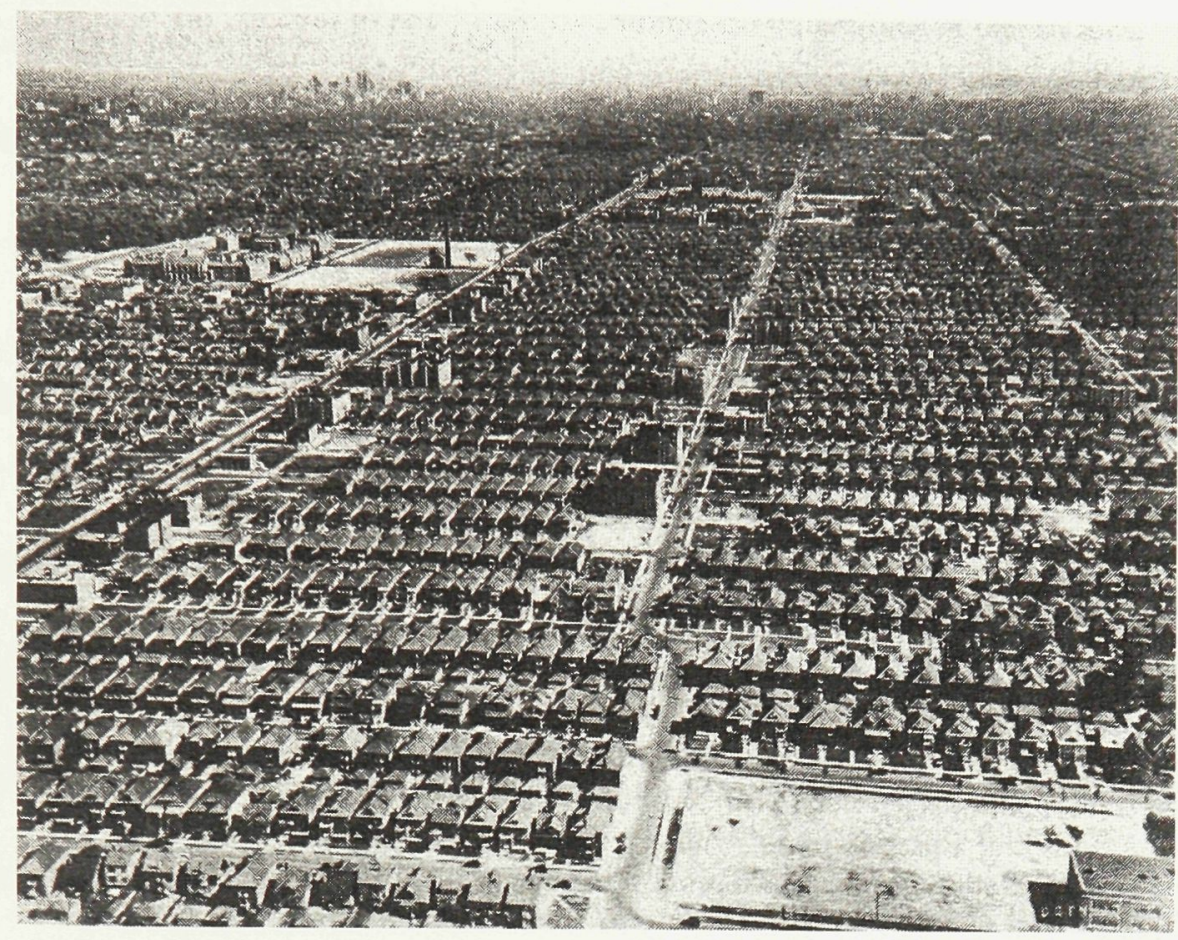

Fig. 3. Single-family detached homes made Detroit a low-rise city, The Origins of the Urban Crisis: Race and Inequality in Postwar Detroit (Princeton. 1996) 21

In the late 1950 s and1960s the combination of rising black incomes and openhousing laws "legalized" the movement of African-Americans into white neighbourhoods. With the economic base already shifting out of the city and into the suburbs following the flow down ever expanding freeways, whites began moving out. Detroit's population dwindled from close to 2 million in 1955 to less than 900,000 today. Racial demographics completely inverted during the same time period. Detroit became a city made up of more than $80 \%$ black residents, with the suburbs more than $80 \%$ white (United States Census Bureau). The neighbourhoods deteriorated as both the industrial and residential tax base shifted to the suburbs. With the same area to service, but half the tax revenue, the results were inevitable. Empty homes and vacant lots spread pathologically. The landscape of Detroit's residential neighbourhoods was forever altered. 


\subsection{The Architect's Role in Housing}

For most of the $20^{\text {th }}$ century, architects in Europe attempted to address issues of housing the masses. In North America the production of mass housing, in the form of single-family dwellings, was predominantly an activity engaged by owner-builders, developers, or merchant builders. Not until after WWII did American architects begin designing housing on a large scale when the government began building massive public housing projects. However, with the demise of these projects there have been very few architects in North America engaged in developing solutions for affordable housing. The reason for this departure is in large part due to the shift in the prime provider of affordable housing from government to private developer. In general, architects do not engage in the design of mass-produced, developer-built housing projects, and as a result have little impact on the form of housing as a whole and more specifically affordable housing. The celebrated houses designed by architects in the late $20^{\text {th }}$ and early $21^{\text {st }}$ centuries tend to be one-off highly customized homes.

In reaction to the government-funded block towers of the 1950s and 1960s, post modern critics urged a return to gridded streets scaled to the pedestrian, as well as a return to designs that integrate a diversity of urban uses rather than segregated residential projects. For a number of reasons, the prime one being little government funding for public housing in the $70 \mathrm{~s}$ and $80 \mathrm{~s}$, what emerged were New Urbanist towns like Seaside that adhered to these values but catered almost exclusively to affluent citizens. Architects engaged in planning entire communities in the New Urbanist style, but the popularity of the developments became so lucrative there was little if any room for low-income residents. 
Construction of most single family dwellings need little detail to be described by the architect for construction, beyond what is needed to acquire a building permit. "A sizable percentage of the house-building market [...] is undertaken by small-scale builders without architectural services [...]" (Davis 77). Residential construction has become so standardized that contractors can estimate labour and material without detailed drawings. Light timber-frame construction details are well known and therefore require little description in the form of drawings or details. Architects or designers tend to organize spaces and apply an overall aesthetic or style, but the contractor or the light-timber frame system of construction imposes decisions on construction. Deviation from standard construction introduced into the design of the project may require special attention by the architect, but contractors are fully capable of building residential projects without architects.

Theoretically, light-timber frame construction is so versatile that the formal possibilities are endless. It can be shaped to incorporate vernacular traditions or contemporary designs, but the realities of cost restraints result in bland developer homes with no relation to their site in homogenous neighbourhoods. Standard and repetitive construction is less expensive, and cost is one of the most important, if not the prime, criteria for most building construction. In the construction of developer homes cost is paramount to guarantee a financial return, as the homes are built to be sold immediately rather than built by a long-term owner. "In no other field of building production is the emphasis on the bottom line so widespread as it is in the US housing industry" (Gutman 18). In the case of affordable housing, the bottom line means standard and repetitive construction finds its way to an extreme conclusion. 
Architects have little input into the construction of mass housing, limiting what influence they have on housing design, which is why stylistic concerns are really all they affect. It is assumed that the introduction of an architect into the production of mass housing will increase costs through fees or construction costs of perceived superfluous designs, but increased value is not always assumed, and decreased costs would rarely be expected. How can architects introduce value into house production beyond stylistic touches? The benefits of a well-designed housing development are quite apparent for the occupants of the development. The ability of architecture to enrich lives is not in doubt. What is not apparent is the ability for architecture to provide an opportunity, not just for good design but to facilitate the manifestation of affordable housing itself. This inability of architects to influence the design of housing at a fundamental level is connected to the lack of meaningful affordable housing and contributes to a reduced ethical and social mandate in the practice of architecture.

Regardless of the criticism of the modern architectural movement, an essential element of the rhetoric of modern architects was an agenda to actively engage in improving the quality of housing for disadvantaged people. In The Design of American Housing, an examination of the architect's role in the production of housing, Robert Gutman laments that architects have drifted away from the cause of affordable housing. "In the past, architects have been among the leading voices in calling attention to the housing problems of the indigent and the disadvantaged, in part because they saw it as an appropriate concern for a profession as distinguished from a business occupation" (Gutman 58). 
Architects are not in a position to influence the production of single-family houses, yet there is a group of people outside the mainstream housing market (in Detroit a large percentage) who lack suitable homes. The building of light-frame timber homes is outside of the practice of architects, yet is still complicated enough to exclude the general public. The need for dignified, well-designed, and well built affordable housing arises from the fact that developers, who are completely tied to the bottom line, are the group entrusted with this socially responsible task. 


\section{$2 \quad$ Standardization}

\subsection{From Craft to Mechanization}

In the United States mechanization in the production of goods first emerged in the textile industry at the end of the eighteenth century and spread to other industries throughout the nineteenth century. As industry embraced mechanization two major changes occurred: the replacement of skilled craftsmen by unskilled labour and standardization. The desire of factory owners to eliminate artisans and craftsmen was economically based. "Early successes with machines encouraged the owners of textile mills to mechanize; they quickly learned that, in addition to increasing productivity and 'saving labor,' textile machines also 'cheapened labor' by reducing the skill required of workers" (Biggs 17). Craftsmen were paid much higher wages than unskilled workers, and there was a large investment in time and money on the part of the employer in training the craftsmen through apprenticeships. "The industrial economy of the early nineteenth century depended on skilled artisanal labor, and its shortage led to high wages - nearly double those paid in some parts of Britain" (Biggs 15). After investing in training, an employer found it very costly to replace skilled craftsmen, and it was difficult to replace a craftsman outright because of a skilled labour shortage. With mechanization came the division of labour. Craftsmen could be replaced by unskilled labourers because jobs were divided to such an extent that an individual worker performed one particular task repetitively, and these unskilled workers could be easily replaced. The larger effect this produced was the ability of factory owners to hire from a larger portion of the population, which in turn lowered the pay of workers. Ultimately, mechanization reduced the overall skill level of the workforce at large. "By the end of the nineteenth 
century, industrialists understood that success of manufacturing lay in mechanization. Special-purpose machines were already helping to build guns, sewing machines, bicycles, and other goods" (Biggs 35).

Although mechanized factories emerged in England before the United States, standardization was a French ideal, which then developed in the United States. In $\underline{\text { From }}$ the American System to Mass Production David Hounshell traces the seeds of mass production in American factories back to the French Enlightenment. Rather than the economic motivations that spurred the development of mechanization in the textile industry, standardization was born out of the "Enlightened military mind" of General Jean-Baptiste de Gribeauval. "Beginning in 1765 Gribeauval sought to rationalize French armaments by introducing standardized weapons with standardized parts" (Hounshell 25). "[...] Gribeauval envisioned a rationalized world of standardized, interchangeable parts" (Hounshell 25). The intellectual influence of the Enlightenment on Thomas Jefferson and the influence of the French military on the United States War Department during the Revolutionary War spurred American arms manufacturers to develop systems of standardized interchangeable parts. Manufacturing standardized interchangeable parts for assembly became known as the American System of Manufactures. Initial attempts at standardizing parts for arms did not necessitate mechanization, but it became clear that mechanization was the route to standardization.

The American System evolved through the nineteenth century spreading to more publicly available goods. The ultimate realization was manifested by Henry Ford and his team of engineers at Ford's Highland Park factory and River Rouge industrial complex in Detroit, where mechanization in the production and assembly of standardized parts 
became known as "mass production" (Fig. 4 and Fig 5). Mass production was more than just standardizing parts. Every movement by man or machine had been streamlined, and the entire process required to build a Model $\mathrm{T}$ automobile from start to finish had been thoroughly analyzed and removed of all inefficiencies. Highly specialized, single-task machines produced standard parts that were assembled on a moving assembly line, which became synonymous with mass production. Ford revolutionized automobile manufacture, making cars available to the general public for the first time. Production of the Model T jumped from " 6,000 units per year to 200,000 in 1913 , to 800,000 in 1919 , and peaked at 2,000,000 in 1923" (Hounshell 268). The utterly staggering production of the Model T seemed to demonstrate the unlimited potential of mass production (Fig. 5). All of industry in the 1920s aspired to replicate what was happening in Detroit.

The benefits of high-quality, low-cost parts that can be used interchangeably, became common practice for virtually all manufacturing. Consumer products, like home appliances, which roll off the assembly line identically, were well suited for mass production. The ethos of mass production was so enchanting, however, that it was felt the same principles could be applied to any and all industry, giving the same benefits in efficiency and productivity. Building materials were easily adapted to mechanized production, and standardized building materials produced in factories began changing the way buildings were constructed and the way architects practiced. Although standardization and mechanization made the production of building parts more efficient and cost effective, the allure of mass-produced buildings transfixed architects Le Corbusier and Walter Gropius. 


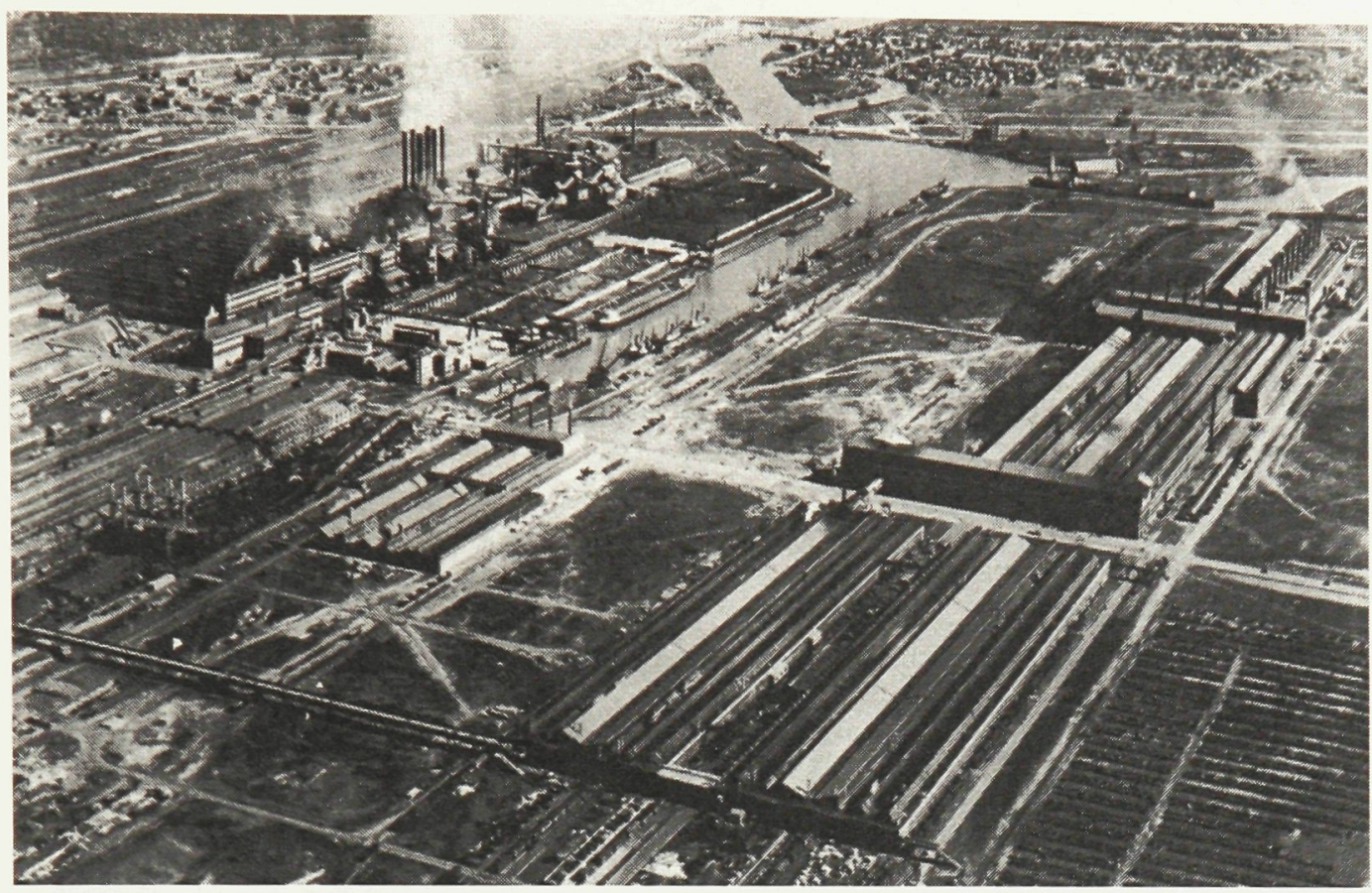

Fig. 4. Ford Motor Company's River Rouge Factory, 1930, From the American System to Mass Production 1800-1932 (Baltimore, 1984) 269.

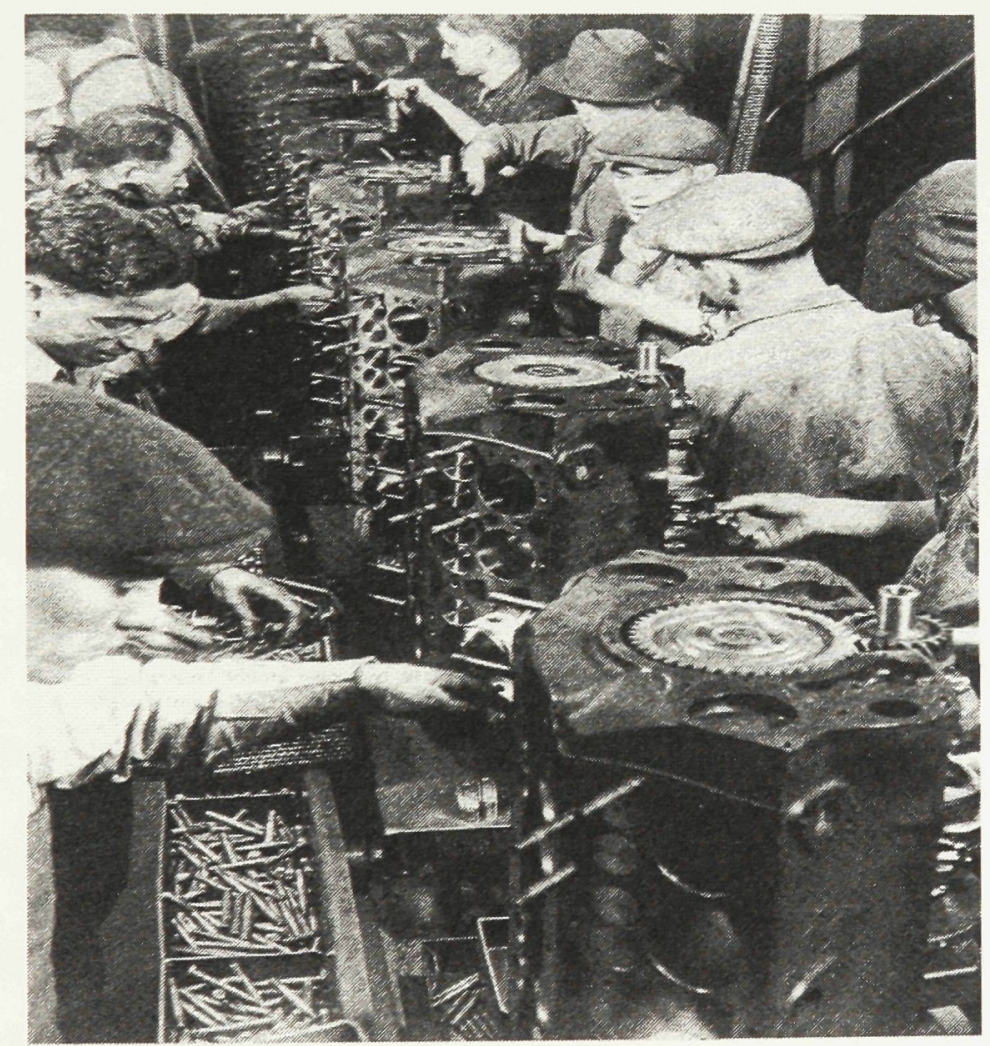

Fig. 5. Ford V-8 engine assembly, River Rouge Factory, 1930s, From the American System to Mass Production 1800-1932 (Baltimore, 1984) 299. 


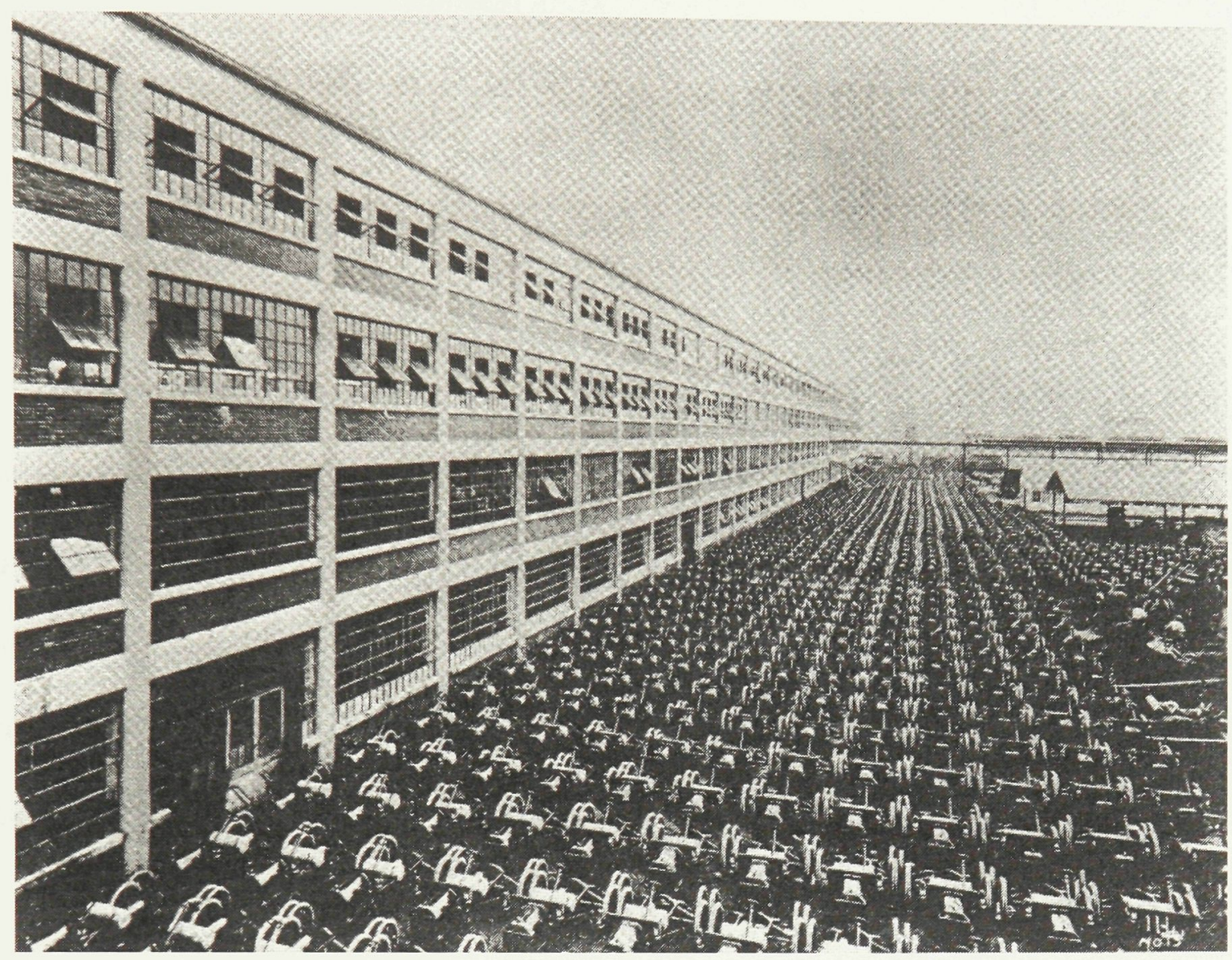

Fig. 6. The output of a single day of Ford Model T's, Highland park Factory, 1915, From the American System to Mass Production 1800-1932 (Baltimore, 1984) 2.

\subsection{Modernism's Embrace of Mass Production, Standardization}

In the early 20th century the modern movement led by architects Le Corbusier and Walter Gropius sought to develop systems of construction based on the same principles that were emerging in factories in Europe and North America. At this time factories were mass producing goods that ranged from automobiles to housewares, which for the first time made these goods available to the working class. Through mass production, high-quality products could be manufactured in enormous volumes and therefore could be purchased at low costs. This is the principle of economies of scale. In relation to the methods and output of factory production, construction methods at the time 
seemed very archaic to the architects of the modern movement. Construction was decentralized, used materials that were mostly handmade and therefore not standardized. With little exception there were no building components produced in factories prior to construction on site. Construction was labour intensive, as building materials were manipulated almost entirely on site.

The modernists saw this new mode of production, mass production, as a vehicle to promote a social and ethical agenda through rational and universal architecture. Mass production was a way to rationalize the design and construction of buildings and in turn to provide high-quality housing for much lower costs. Their goal of providing new, dignified housing for the working-class citizens of crowded slums could be achieved through an architecture of mass production.

If modern architects and the construction industry could emulate the way factories were producing goods, then building construction could be radically altered. In order for the construction industry to adopt these methods, construction materials would need to be standardized. Gropius outlines the extent of the standardization required.

Before this is practicable, however, every part of the house-floor-beams, wall slabs, windows, doors, staircases and fittings-will have to be normed. The repetition of standardized parts, and the use of identical materials in different buildings, will have the same sort of coordinating and sobering effect on the aspect of our towns as uniformity of type in modern attire has in social life. But that will in no sense restrict the architect's freedom of design. For although every house and block of flats will bear the unmistakable impress of our age, there will always remain, as in the clothes we wear, sufficient scope for the individual to find expression for his own personality. (Gropius, New 40)

Early in his career, while working for architect Peter Behrens, Gropius proposed to Allgemaine Electricitäts Gesselleschaft (AEG) a program for developing an industrialized house. "Gropius submitted his Programm zur Gründung einer allgemeine 
Hausbaugesellschaft auf künsterlich einheitlicher Grundlage, m.b.H (Program for the Founding of a General Housing-Construction Company Following Artistically Uniform Principles) to Rathenau of AEG in April 1910" (Herbert 33). The conceptually advanced, but technologically ineffectual proposal did not come to fruition but was the antecedent for much of Gropius's work as an architect and educator. From there he went on to explore his theories at the Bauhaus. As director he introduced the idea of standardization into the curriculum of the Bauhaus. In order to take full advantage of the emerging technology, Gropius felt that architects and designers needed to begin designing within the mindset of mass production. Inherent in this idea is that architects should be influencing the production, not merely designing buildings with standardized parts, but influencing the design of the parts themselves. The architect should be playing an integral role in the way this new technology is going to influence architecture, and through the Bauhaus architects would be trained for design in the Industrial Age. "Who is to understand the building as the organizing factor of our life's processes? And who is to integrate the scientific, social, technical and economic factors, inherent in the new architecture of the industrial age? Gropius's answer here is unambiguous. This integrative role is the essential task of the architect, and therefore of necessity he must be involved in the process of industrialized building of houses" (Herbert 62).

Le Corbusier, who also worked for a short time at Behrens's office, was intrigued as much as Gropius by the potential of industrialized building. He expounded upon the need to adopt industrialized house construction in Towards a New Architecture, and furthered his rhetoric through the CIAM. "Dwellings, urban and suburban, will be enormous and square-built and no longer a dismal congeries; they will incorporate the 
principle of mass-production and of large-scale industrialization. It is even possible that building 'to measure' will cease" (Le Corbusier 235). Although Gropius was perhaps the pioneer with his proposal to AEG in 1910 and his pushing his agenda for industrialized building through the Bauhaus to burgeoning architects and designers, Le Corbusier is the one who ultimately advanced the cause. "Conceptually Le Corbusier adds nothing new to the basic formulations of Gropius. Yet ironically in the coming years it is Le Corbusier, not Gropius, who ignites the imagination of a generation of architects; it is not the reasoned arguments of Gropius but the stimulating force of Le Corbusier's visual images, and the evocative power of his prose, that leads the Modern Movement in its drive for industrialization and standardization" (Herbert 39).

A subtle difference between Gropius and Le Corbusier is the position of the architect in relation to industry. In Towards a New Architecture Le Corbusier places the architect in a passive role awaiting the time when "big industry" has sorted out the process. "In the next twenty years, big industry will have coordinated its standardized materials, comparable with those of metallurgy" (Le Corbusier 234). Again his faith in industry is revealed when he writes: "The morality of industry has been transformed: big business is today a healthy and moral organism" (Le Corbusier 284). Le Corbusier is correct in his prediction that industry will standardize construction materials. His placing of the architect in a passive role was perhaps a self-fulfilling prophecy, as advances in standardized industrial building left the architect outside much of the process of conceiving and developing building materials.

Many architects and home builders attempted to apply the principles of mass production in the production of prefabricated houses, which, with the exception of the 
mobile home, made little impact. Building materials were successfully adapted to massproduction methods, but whole houses seemed an elusive task. Gropius worked with fellow German architect Conrad Wachsman to develop a prefabricated house made up of standardized parts that could come together to form many different models of houses, producing variety within a housing development (Fig. 6). After arriving in the United States after WWII, the two architects with help from investors incorporated a company, General Panel (Herbert 280-282). The endeavour, like most of the prefabricated house attempts was a failure. Caught up in the zeitgeist of mass production, General Panel and the others sought to emulate the factory-based production of the automobile. Gilbert Herbert sums up the problem in The Dream of the Factory-Made House:

[...] hoping to produce a factory-built product competitive in quality with the traditionally built houses of the tract developer, at a significantly lower price; this was the goal of General Panel, as it was of most other prefab firms. In this formidable task, where the high costs of research, development, and tooling could only be offset by large-scale production, the advocates of the factory-built house turned again and again to the paradigm of the automobile for encouragement and for justification. But this analogy was a false one. Car prices initially were high, to cover high tooling costs and disproportionate overheads, while production slowly increased. But as a generic product the car was unique, and its manufacturers had a complete monopoly; one either paid the high price or did not acquire a car. Eventually, of course, production rose to levels where prices could significantly be reduced, generating even larger demand. In more recent times one could see a parallel in the manufacture and marketing of computers. But industrialized housing did not produce a unique product, the competition of the traditionally built house was an ever-present factor, and the industry was denied that sheltered growth period it needed to reach the critical level of mass production. (Herbert 308)

Even before the General Panel failure, while the house was in production, although developed with the idea of producing many different variants, the factory only produced parts for one model of house and marketed it as just that, a single prefabricated house.

Because General Panel was a business venture, financial priorities overrode any design intentions. Gropius lamented over the fact that the architect had little influence over this 
method of production. "Instead the idea of prefabrication was seized by manufacturing firms who came up with the stifling project of mass producing whole house types instead of component parts only. The resulting monotony further deepened the horror of a nostalgic, sentimental, unguided public of a prefabricated future" (Gropius, Appollo 318).

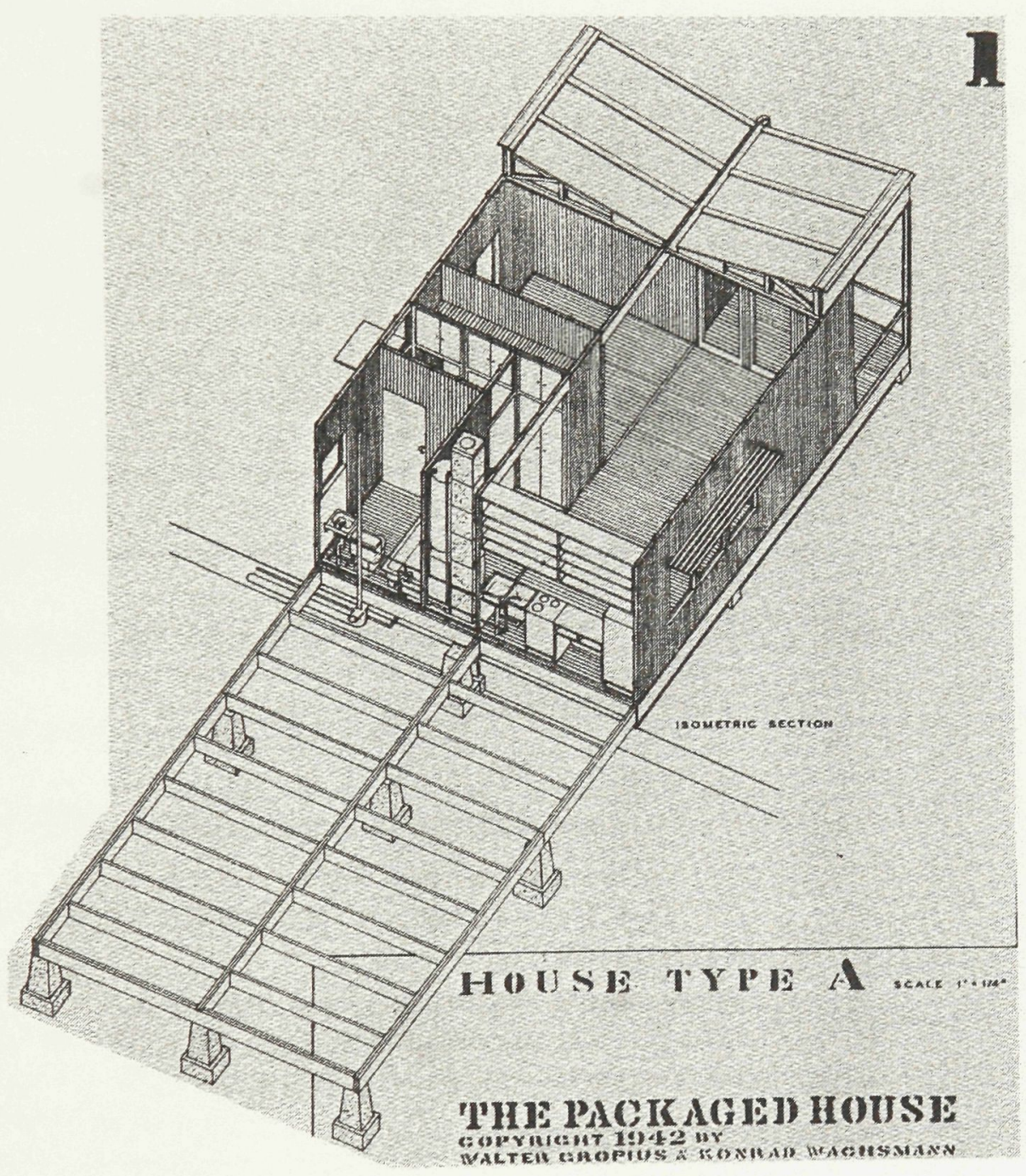

Fig. 7. Prefabricated house for General Panel, The Dream of the Factory Made House (Cambridge, 1984) 261 


\subsection{Standardization in Contemporary Construction}

Today we have reached the point where nearly all building materials have been standardized. Bricks, blocks, studs, and sheathing are all mass produced in factories, and their modular sizes interrelate to allow for standard construction details. In theory, variety can easily be attained through the use of standard $2 \times 4$ construction. Gropius's and Le Corbusier's ideas of standardization in their basic and technical sense seem to be realized. What has changed (or maybe never developed) is the position of the architect in relation to factory production and the accompanying social and ethical position. The transformation of the construction industry into a highly industrialized corporate endeavour left the architect in a position of lesser power. "Following Marx's predictions, mass production became the reserve of increasingly large firms and global corporations, and much of the making of everyday items-new modern necessities-became a virtually invisible activity, $[\ldots]$ " (Callicott 33). This is the system in which architects currently practice- a system that theoretically allows for infinite variability but often becomes a practice of either merely choosing products and systems for economy, or creating custom designs at exorbitant costs.

In many instances design is inevitably reduced to the specification of components and systems originally conceived without reference to the uniqueness of the project, either as a technological or social construct. The level of uniqueness inherent to any individual building project necessitates a high level of innovation, which often appears incompatible with present client demands for reliability and economy. (Callicott 41)

The construction and building-product industry influence the way architects practice rather than the influence Gropius felt the architect needed to exert over industry.

By definition, to standardize something means to reduce to or bring into conformity with a standard. An entity produced in series that has been standardized is 
identical, or nearly so, to the standard and all the other entities produced as well. If there is no difference between entities, then it could be said that to standardize means to eliminate variation among entities in a series. Therefore, an entity that is standard exhibits little or no variation from the next. The concept is therefore not connected to form. If a series of objects are all radically complex geometrically, yet all have the identical complex geometry then, they would be considered standard. If another series of objects have simple formal qualities, yet each entity of the series is different, then they would not be considered standard, but rather non-standard. This concept of standard and standardize is related to mass production in a manufacturing setting where the production of a series is connected to a mold or die from which all of the entities have been created.

The construction of buildings is different from the manufacturing of goods in a factory. In the construction industry there are certain norms for construction, especially in the construction of houses in North America. "By standardizing building forms, the construction process seeks to reduce variations within any building type, offering benefits in productivity that increase exponentially with quantity" (Callicott 41). Stick frame walls consist of studs with top and bottom plates infilled with vertical studs, and the overall form of the wall is orthogonal. It is standard practice to design and build a wall in this fashion. In construction there are standard designs for assemblage of standard components. There is standardization from component to component (studs, plywood), from assemblage to assemblage (wall, roof, floor), and also within a component such as a wall. A wall is more easily constructed if it exhibits little variation within itself. If there are window openings within the wall, or if the form of the wall changes in either plan or section, these variations within the assemblage itself increase the complexity of 
construction. Inherent in the system is that variation means the customization of standard parts and that customization takes place on site. More customization means more labour, which increases the cost of construction. Fastening $4 \times 8$ sheathing to a wall or floor without modification is less expensive than if the sheathing needs to be cut prior to being fastened. If the goal is to reduce costs and the price of construction materials is fixed, the design that requires the least labour will be the least expensive. Walls with the least amount of variation are orthogonal, with as few openings as possible, preferably none. Roofs and floors follow the same logic. Since affordable housing by nature should be inexpensive to build, the same ruthless logic is applied in excess. There is no one standard that generates the building, but less variation means lower cost. Therefore, in the construction of a building the concept of standardization is not completely restricted to the production of a series.

Houses are not serially produced like automobiles, and therefore do not achieve the same cost savings through mass production in the true sense of moving assembly lines, highly specialized single-task machines, repetitive tasks by workers, efficiency studies, and the outright replacement of workers by machines or robots. That being said, there are still tremendous cost savings from one house to the next if there is little variation among houses within a large housing development. A non-standard condition in one house can increase costs, but if that condition is then repeated in a series of identical houses, the knowledge of repetitive construction will keep the cost of the series lower than if the unique condition continued to change from house to house. An investment in the fabrication of templates and jigs can be made if the non-standard condition becomes repetitive, and wrinkles can be ironed out as the process progresses. It 
is the knowledge that there will be repetitive construction of foundations, walls, and roofs that reduces costs.

In summary, there are two inter-related concepts of standardization in house construction. The first relates to building components. This is the concept related to factory production, whereby an entity is produced in series and is the same as every other entity in the series. This notion of standardization is not related to form. The second concept comes from standardized methods in the assembly of these components (studs into walls), and is therefore connected to the form of building components. The repetitive assembly of components on site does not achieve the same benefits in cost reduction as factory production, but there are still significant cost savings especially over a large housing development. Architects have the most influence over the second concept and essentially no control over the first. However, the control architects have over the assembly of components is directly connected to the cost of labour on site. Current and past attempts at industrializing house construction have focused mainly on panelization of buildings for in an attempt to lower costs in the assembly of building components before they get to the site. Walls, roofs, and floors are prefabricated as panels and assembled on site. This significantly reduces labour on site. The variation from house to house is accomplished through the different ways in which the panels are combined to form the house. If incorporating variation into the design of a house is important and if the construction consists of standardized components rather than nonstandard components, then smaller components rather than larger standardized components such as prefabricated panels offer the most potential for introducing 
variation to the design. For prefabricated panel systems, the assemblage has become the component.

In the design of mass housing, it is difficult to create non-standard houses without the customization of standardized parts. Customization however, is more expensive than the default construction, which persists because of on-site labour costs. It is a question of scale, (component-stud, plywood, brick; assemblage-floor, wall, roof; house; neighbourhood) whether assembling standard components that are the size of studs into a custom building or assembling prefabricated panels or room-size modules into a custom house or constructing a series of homes along a street. If architects truly wish to influence the production of affordable housing, which by necessity demands lower costs, it must be at the level of production of the building components themselves. 


\section{$3 \quad$ Building}

\subsection{Drawing for Construction}

The changing social and cultural climate of the Industrial Revolution dramatically altered the way buildings were designed and constructed. The current adversarial relationships that exist between architect and contractor developed at the same time that industrial processes began influencing construction and modernist architects. In Building Culture, Howard Davis tracks the evolution of the modern architect and contractor, and the formalization of their relationship throughout the nineteenth century into the roles that exist today. In North America the title of architect and the legal ramifications of being an architect begin to be formalized with the establishment of "the American Institute of Architects in 1857 and the first American school of architecture, at the Massachusetts Institute of Technology in 1868" (Davis 121). Prior to these formalizations the role of architect as one who designs and specifies a building for construction, and the role of contractor as one who carries out the construction of buildings, were not so rigidly defined. Before accredited schools of architecture and professional architecture associations developed, the roles of architect and builder were blurry.

The driving force that formalized the role of architect and contractor was the building contract between contractor and client. Contracts became less ambiguous and increasingly explicit from the eighteenth through the nineteenth century. "Not only is there increased detail; in addition, adjectives that call for subjective interpretation disappear. Words and phrases like good, well burnt, strong doors, proper hinges and fastnings, (sic) good and sufficient fastenings (sic) appear in the earlier contracts. In later 
contracts, such adjectives are eliminated and replaced with quantitative descriptions or with qualitative descriptions that go into considerably more detail" (Davis 188).

Drawings and specifications for a building took a central position in the building contract.

Because the roles of builder and designer had diverged, the drawings and specifications prepared by the architect needed to be as accurate and detailed as possible to enable the contractor to estimate the cost of construction accurately. The architect also became the client's agent on site responsible for confirming work completed by the contractor and ensuring compliance with the contract by the contractor.

As the relationship between contractor and architect evolved, the craftsmen, the artisans who carried out the manual work of shaping the building, became less and less able to carry out their work independent of the architect. Prior to this change, craftsmen did not need working drawings, and therefore architects did not produce them. Marco Frascari discusses this relationship in The Tell-the-Tale Detail.

[...] architects did not have to prepare working drawings showing the construction of the details. The drawings carried few if any details and dimensions. The designer could be almost entirely dependent on his craftsmen. Builders had no need for drawings to show details whose execution was a matter of common knowledge. Construction of details was parceled out among the various tradesmen, who supplied the necessary knowledge. (24)

The changing nature of building design and construction brought about a

fundamental change in the production of details. The location of production shifted from the construction site to drafting board.

[...] building trades no longer inferred the construction of the detail from design drawings. The details were studied and resolved on drawing boards. Draftsmanship was substituted for workmanship, and the development of 'real details' was replaced by 'virtual' procedures. From this point of view the detail was no longer seen as a joint; instead, it was seen as a production drawing. In this interpretation 'details' are verbal and graphic means for controlling the work 
of variable crews of vocationless workers who are unprepared for their own jobs and possibly even financially dishonest. (Frascari 26)

This shift was a product of a society that was "predominantly economically motivated. [...] No longer considered as long lasting cultural and social repositories, buildings came to be viewed as economic investments with an intentionally planned short existence" (Frascari 26 ). This same economic motivation, although later in history, can also be attributed to the shift of government policy in the 1970s. The government ceased to build affordable housing instead turning to private developers. Social housing becomes affordable housing because it is not a social investment.

The preparation of detailed working drawings and specifications had the same deskilling effects on craftsmen on construction sites as the mechanization of factories had on craftsmen producing goods in the eighteenth century. Highly detailed construction documents lowered the necessity of skilled craftsmen and thus reduced the overall knowledge of craft based production. It is a self-fulfilling prophecy as architects are required to produce more and more drawings and simultaneously lament over the fact that there are fewer and fewer workers with the skill to construct their design. Architects are not directly to blame for lowering the level of skill among construction workers, as an increasingly litigious society dictated that more detailed specifications and drawings be prepared to meet the increasing contractual nature of building construction.

Mechanization in factories also affected craftsmen on construction sites directly. The introduction of mass-produced, standardized building components also lowered the requirement for skilled labour, as more and more construction materials were being produced in the factory rather than being shaped on site. "[...] a good deal of processing 
takes place in factories, and the building worker's job is either to cut a processed material, such as gypsum board or plastic laminate, or to install a premanufactured component, such as a vinyl window" (Davis 79).

The term 'craftsman' is rarely used to describe workers on today's construction sites. More often the terms fabricator, sub-contactor or sub-trades are used to describe the group of workers employed under the contractor. The evolution of the construction industry has reached the point where the design of a building needs to be explicitly communicated to contractors, fabricators and sub-trades. "Contracts have now evolved to the point where everything is specified" (Davis 195). Architects communicate the design to the contractor in the form of construction documents, a combination of drawings and specifications. Drawings prepared for contractors are, as discussed above, contractual documents, central to the building contract. Prior to construction, these documents are used to estimate the cost of construction. The more detailed a set of working drawings, the more likely the estimated cost of construction will be the same as the actual construction costs. Contractors are able to gauge the cost more accurately if there are fewer unknown conditions for construction. Prior to construction contractors and their sub-trades prepare shop drawings, which are submitted to the architect to communicate the precise details of fabrication for construction. They are based on the architect's design but are completely separate drawings, which most often have been redrawn from drawings prepared by the architect. Even though most architectural practices produce drawings with $\mathrm{CAD}$, the digital files are rarely passed along to fabricators to produce shop drawings. Because shop drawings are produced by 
contractors or fabricators, they are a device that places much of the design liability in the hands of the contractor.

The traditional method of description from architect to builder is orthogonal drawing, which has been replaced or supplanted by CAD. Whether hand-drafted or $\mathrm{CAD}$, the drawings produced as construction documents are two-dimensional plans, sections, and elevations. Two interconnected issues arise when non-standard design is introduced into the construction of a building. How can the non-standard condition be described by the architect, and how will this non-standard condition be constructed by the contractor? Orthogonal drawing conventions make drawing orthogonal forms easier than drawing organic or amorphic forms. Non-standard or non repetitive conditions also require more drawings. Since drawing is the means through which architects communicate the formal qualities of a building to contractors, buildings made up of straight lines are what contractors build. But the relationship is a reciprocal one. Orthogonal drawing conventions translate well into built form because there are analogies between these conventions and traditional fabrication methods. Bricks and blocks are made with right angles and tools that cut, like radial saws, tend to cut in straight lines the same way lines are drawn straight on a drafting board. The explosion of 'blobs' onto the architectural scene in the 1990s was directly related to the abandonment of drafting boards in favour of computers.

In the 1990s avant garde architects and architecture students began experimenting with software developed in the automotive, aerospace and animation industry. "In these fields, with the aid of ever increasing computer power and ever more sophisticated display technology, free-form curved surfaces became as straightforward for designers to 
handle as straight lines, planes, circles, cylinders, and spheres were for architects" (Mitchell 356). The designs that emerged from the digital experiments were highly amorphic and fluid. Architect Gregg Lynn gave the resulting architecture a name with his essay Blobs. The irregularly shaped designs criticized by many, were if nothing else a break from traditional orthogonal building forms. Most of the designs remained virtual, however, as traditional methods of construction and fabrication in the building industry did not lend themselves to the blob-like forms.

The explicit description of non-standard designs to contractors through traditional drawing methods requires the production of many drawings. The construction of nonstandard designs leads to increased labour and material wastes because standard building products require customization on the construction site. The same analogy between drawing with orthogonal conventions and fabricating with orthogonal tools has led architects of amorphic and non-standard designs to the use of fabrication technologies employed by the aerospace and automotive industries. In $\underline{\text { Hybrid Space, }}$ Peter Zellner presents the work of several architects (Lynn, Kolatan/Macdonald, dECOi) designing and fabricating with digital tools. These same architects that experimented with the use of automotive and aerospace software for designing began utilizing the digital fabrication methods of these same industries because of the inherent link between design medium and fabrication.

\subsection{CNC Digital Fabrication in Architecture}

The North American automotive industry by the mid twentieth century had eliminated virtually any handcrafted parts in the production of cars through highly 
mechanized manufacturing technologies. The aerospace industry was still utilizing some craft based methods of production because of the more complex geometries of aircraft. "This approach reflects the much smaller quantities and greater complexity of products required [...]" for aircraft (Callicott 45). In order to eliminate costly skilled labour and expedite the production of aircraft, the United States Air Force sought sophisticated manufacturing technologies that could shape parts for the demands of supersonic aircraft following World War II. "High speed and maneuverability also equated to high stress on aircraft structures and the need for structural strength. All these factors added up to a requirement for new machine tools capable of sculpturing highly complex structural shapes from the lightweight materials suitable for operation in a high temperature environment" (Reintjes 135). Through collaboration with the Massachusetts Institute of Technology, the US Air Force developed a system of controlling milling machines through digital inputs in the early 1950s. These early developments controlled milling machines with inputs on punch cards. In the same way that standardization spread from military applications to industries producing public goods, numerical control, or NC, quickly spread to general machine shops. Current digital fabrication technology communicates information from computer-generated models directly to manufacturing equipment. Computer numerical control or CNC technology used in the automotive and aerospace industries allows for direct computer input to traditional fabrication equipment including milling centres, routers, cutters, and benders. The technology is making its way into the construction and architectural world being put to use in a range of construction-related industries from cabinet-making to signage. 
Unlike traditional fabrication tools, $\mathrm{CNC}$ fabrication is not restricted to orthogonal movement. CNC cutting tools can move in two axes. The difference between making a straight cut and a curved cut is negligible. CNC water-jet and laser cutters can efficiently cut two-dimensional shapes from sheathing and relatively thin materials (Fig. 8). CNC routers and mills move in three, four, and five axes (Fig. 9). Complex threedimensional topography can be shaped out of large blocks of material (Fig. 10).

The connection between design medium and fabricating has become radically closer. Architects have the ability to output virtual geometry directly from threedimensional computer models to $\mathrm{CNC}$ cutters, mills, and routers. The new descriptive abilities offered to architects through $\mathrm{CNC}$ and other digital fabrication technologies provide a new way of "describing" architecture to fabricators and contractors. This method of description brings into question the relevance of working drawings and more specifically shop drawings. For non-standard construction the dual problematic condition of description and construction can be mitigated. Orthogonal drawings are no longer required to describe the situation, and complex geometry is easily shaped by CNC machines. The ability to fabricate highly complex and amorphic forms, and the ability to construct a building of completely custom components is being explored by architects. It allows previously unbuildable complex geometry to be realized at an acceptable cost. The true significance of $\mathrm{CNC}$ fabrication, however "lies within its ability to initiate a rare reaction between conception and execution, whose implications go well beyond those which can be explained using economic principals alone" (Callicott 20).

CNC technology is a decentralized and low-capital investment compared to factory prefabrication. CNC machines are economically available to architects for 
operation within their own office, and their use has become widespread enough that in most large cities metal fabricators and wood-working shops are currently utilizing them. Prefabrication in factories requires large capital costs to initialize production and requires steady demand and output to maintain operations. The rigidity of factory-based production makes spontaneous intervention by architects nearly impossible. Factorybased production only weakens the position of the architect, as maximizing efficiency and profits in order to recover costs incurred for research and start-up takes precedence over design. Walter Gropius's experience with the packaged house system illustrates this point. After developing a system of interchangeable parts to be used to build many different house models, the factory instead produced parts to be sold as one basic model. The ability to serially produce non-standard building components means that rather than searching for a universal modular system, one that fits every situation, a system that is unique to an individual project can be developed. 


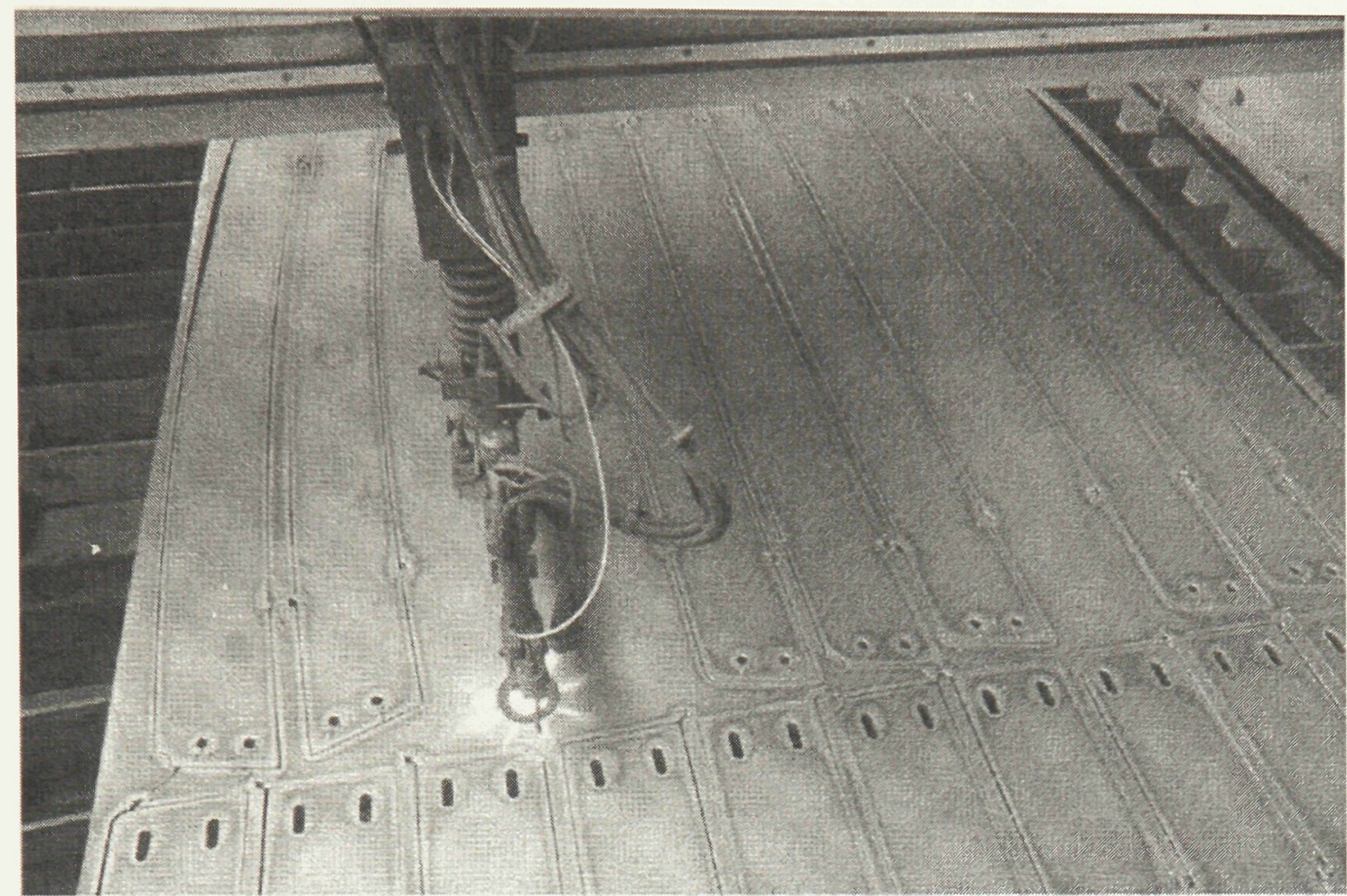

Fig. 8. Plasma-arc CNC cutting of steel supports, Architecture in the Digital Age: Design and Manufacturing (New York, 2003) 34.
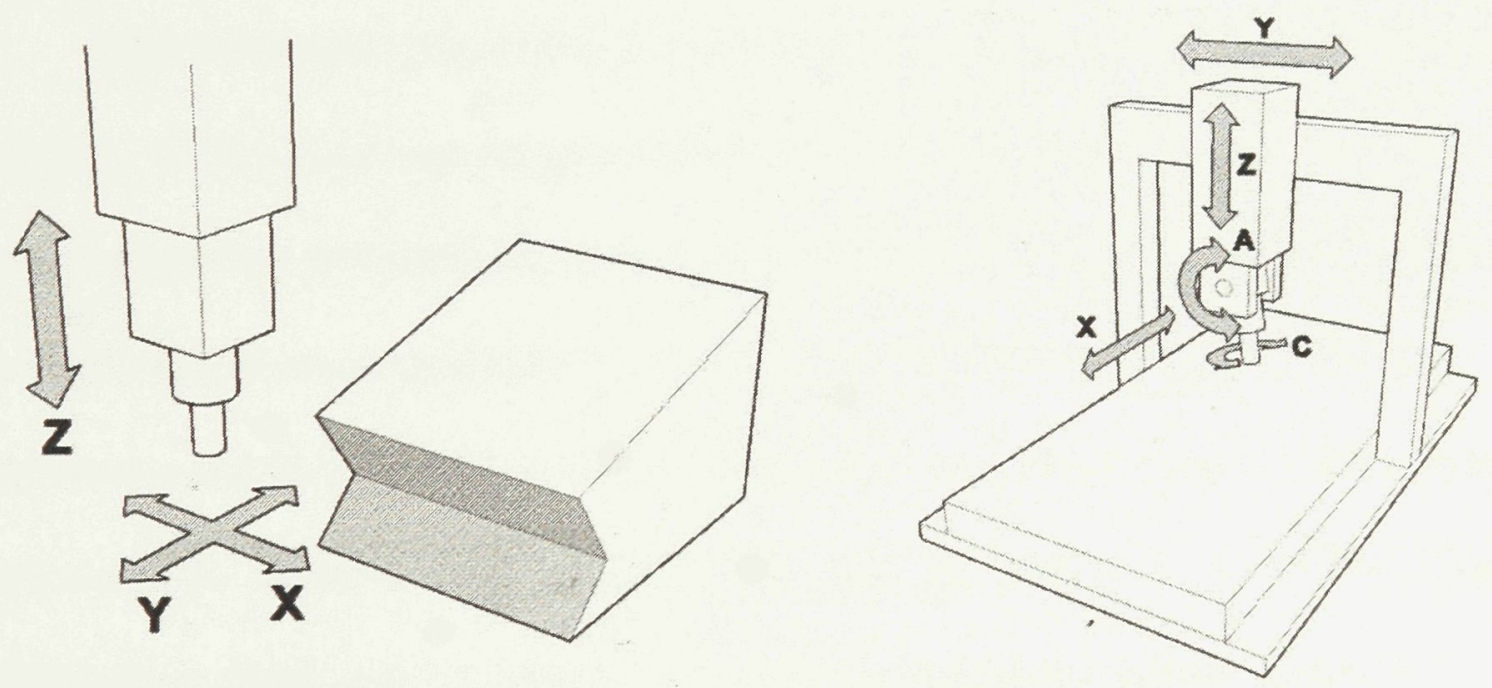

Fig. 9. Three axes and five axes mills, Architecture in the Digital Age: Design and Manufacturing (New York, 2003) 34. 

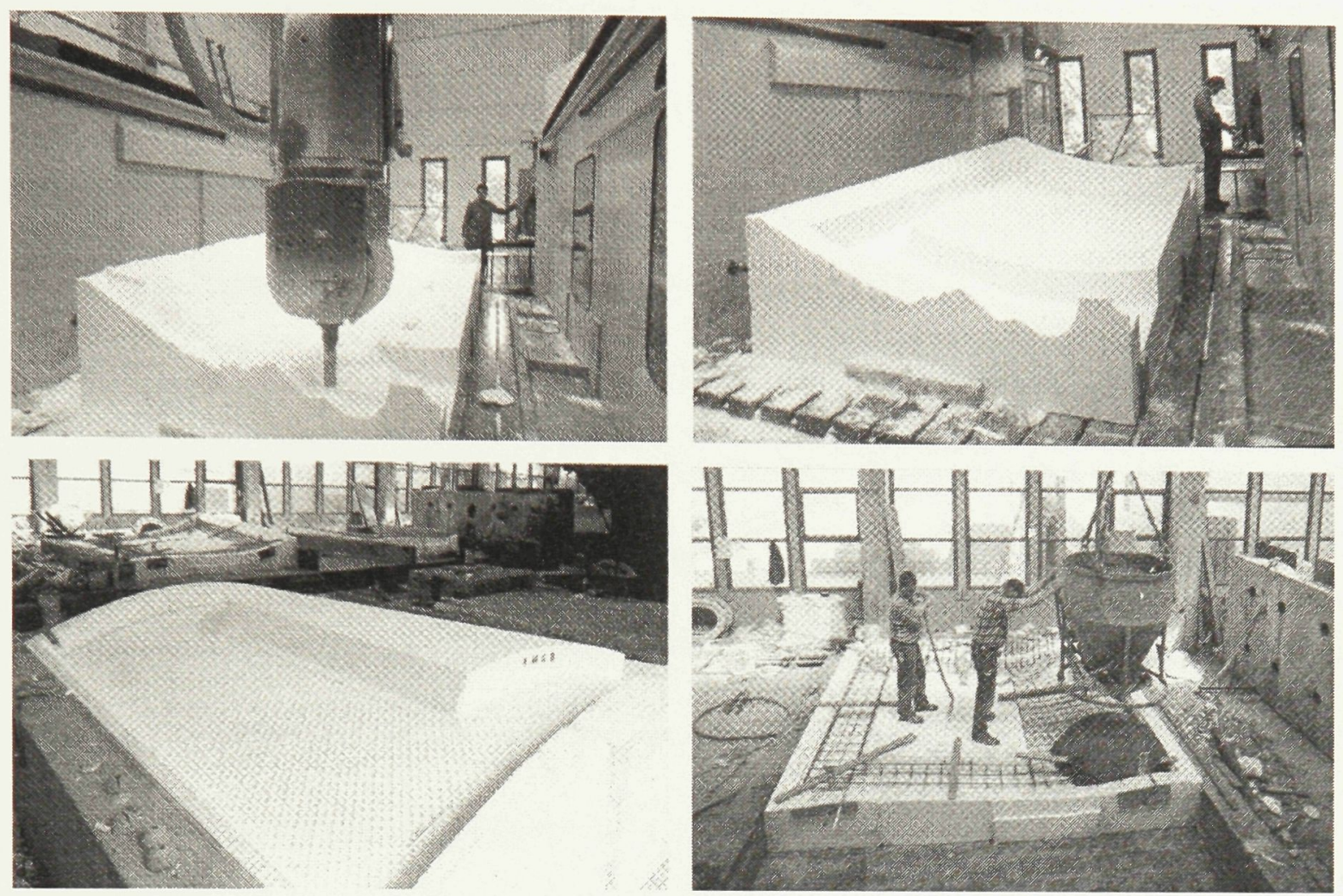

Fig. 10. Contouring of rigid foam for pre-cast concrete panels, Architecture in the Digital Age: Design and Manufacturing (New York, 2003) 36.

\subsection{Digital Master Builder}

Marco Frascari sees architectural detailing as fundamental to the success of a building. "In the details are the possibilities of innovation and invention, and it is through these that architects can give harmony to the most uncommon and difficult or disorderly environment generated by a culture. [...] Careful detailing is the most important means for avoiding building failure, on both dimensions of the architectural profession-the ethical and the aesthetic" (23). The near limitless capability of CNC fabrication to shape and cut complex geometry into architectural components is analogous to the tantalizing shift to industrial production modernist architects sought to capture, but facilitates for interventions on the part of the architect. The opportunity that arises for architects is the ability to embed details, the place where innovation and 
invention are possible, into fabricated building components, rather than merely designing formally complex buildings with the assumption that someone else, the contractor, will have the methods to build it.

Details produced by architects can be integrated into components during fabrication, similar to the way some building components are shaped in the factory. The edges of wood sheathing, hardwood flooring, and rigid insulation are fabricated with tongue-and-groove connections so that adjacent pieces can easily slip into place and therefore reduce time spent fastening the sheathing. For the architect to change the tongue-and-groove connection, or to create a similar connection system in materials without such a system, would require either an intervention in the production of the sheathing at the factory or the architect's specifying or drawing details that would be carried out on site. Both of these alternatives would be costly for different reasons. An intervention into the production would be costly because of the inherent rigidity of a highly mechanized production facility. Change to the end product would require a change of machinery. Drawing or specifying the detail would require more labour on site and the production of shop drawings. Both alternatives would negate the intention of a prefabricated joint system, that of saving labour and time during construction, a costsaving strategy.

By fabricating geometry directly from a computer model, rather than a fabricator producing shop drawings, architects exert more control over the construction through the detailing of architecture. This introduces a new way to collaborate with fabricators and work more closely, rather than almost exclusively through drawings. The architect's role on the construction site is to confirm work completed by the contractor, which leaves 
little or no opportunity for the architect to shape a building on site by working with fabricators or sub-trades. Working directly with fabricators, rather than through the contractor, has led some to call this emerging role of the architect as digital master builder, analogous to the time when architects worked directly with craftsmen and were more involved with construction. "In contemporary circumstances, the master builder is someone who is fully involved in the making of the buildings, where the making means design, production and construction in an almost medieval fashion" (Kolarevic 65) Rather than continuing to accept factory-based production or continuing to pass on risk to fabricators, architects need to step out of the passive position that Le Corbusier predicted. Architects must be in a position to take advantage of the opportunity provided by the technology, collaborating with fabricators early on in the design and having an understanding of the capabilities of various fabrication equipment and limitations of materials.

An architectural firm that typifies the idea of digital master builder is that of Frank Gehry. Jim Glymph, one of Gehry's partners feels that the collaboration between the architect and fabricators is fundamental to the firm. "The notion of working with materials and fabricators in a collaborative way is something that Frank has probably been engaging in his whole career" (qtd. in Cocke 54). Essential to making this new digitally-driven practice to work is "to establish a very strong bridge between us and the fabricators, the craftsmen, and the people executing the work [...] (qtd. in Kolarevic 65) Architects working directly with fabricators goes against the traditional relationship between architect and general contractor. Fabricators are employed by the contractor, not by the architect. The lines of liability become blurred. Glymph sees resistance from 
contractors because "this kind of exchange between the architect and the subcontractor more or less violates the basic ground rules for how construction projects are managed" (qtd. in Cocke 54). The traditions and relationships within the building culture may make change more difficult to achieve than any technological issues.

The concept of architects as master builders is associated with a time period where craftsmen shaped the building while working with the architect on site. Craftbased production in the traditional sense is not undesirable or obsolete. However, it is expensive, and if viewed as the only way to generate architecture, ethical affordable housing will be unattainable in a construction industry dominated by economics. To attempt a revolt against the current system of construction by putting detailing back in the hands of tradesmen on site is nearly impossible for affordable homes because the entire financial and construction system is averse to risk. Ambiguous construction documents with details that are to be determined on site, rather than detailed drawings and specifications, are perceived by contractors as higher risk and therefore costlier. Simply put, a project that requires a large amount of skilled labour is too expensive for affordable housing.

Detailing in the economically motivated world of standardized design and standardized building products is often a battle between architect and contractor-even between architect and the system of construction in use. This is especially true in the production of mass housing, an industry where cost savings are expected in repetitive construction and builders tend to resist innovation. Previously labour-intensive construction (which would be cost prohibitive for affordable housing) can be realized 
through this new method of detailing that can bring an ethical and aesthetic dimension to affordable housing. 


\section{$4 \quad$ Precedents}

\subsection{FOG/A architects}

Frank Gehry’s firm, Gehry Partners, has been a pioneer in integrating digital technology into design development and construction administration stages of architectural design, and in demonstrating that digital fabrication technologies can be used on large-scale, large-budget buildings. Most of Gehry's designs would have either been physically unbuildable or so cost prohibitive that they would have been economically unbuildable without the integration of digital modeling tools and the ability to directly fabricate components of the building with various digital fabrication technologies.

The design methodology of Gehry begins with the creation of a series of physical study-models. After making several physical study-models of the building, the models are digitized and further developed as three-dimensional computer models within software called CATIA. Design development of the building is then done through the computer model in CATIA (Fig. 11). The same computer model generates the construction documents, or most often the computer model itself is used as a construction document. Through the use of digital modeling and fabrication technology in his practice, Gehry places himself in a position of control over the design and construction process. "This technology provides a way for me to get closer to the craft. In the past, there were many layers between my rough sketch and the final building, and the feeling of the design could get lost before it reached the craftsman. It feels like I've been speaking a foreign language, and now, all of a sudden, the craftsman understands me" 
("CATIA"). Gehry's digital design methodology is more than just putting digital technology to use; it is challenging the culture of building.

The innovative aspects of Gehry's practice is the way in which it is changing the relationship between architect and contractor as well as the legal ramifications of this change. Gehry reveals his contempt for the present situation in which architects operate, when he describes the relationship between the architect, client, and contractor.

The American legal system, the insurance system, and the tradition of the architect-client-contractor relationship are based on a bunch of phony assumptions. After the architect designs the building and does the drawings, he rises from the floor five feet and becomes the holier-than-thou arbiter between the client and the contractor. That's the assumption of the old system. What really happens is that the contractor goes to the owner and says, 'If you straighten this wall out, I can save you a million dollars,' and the client says, 'Wow!' and sometimes he does it. The contractors, because of their relationship to the money, become parental in the equation, and the architect becomes the child-the creative one. 'Here comes the creative one again; watch out'. (qtd. in Friedman 53)

Gehry's anecdote is anathema to the way his practice works. His wavy, nonorthogonal building designs require three-dimensional computer modeling tools to develop and coordinate the entangled structural steel and compound-curving metal skins. The three-dimensional model becomes the construction document. The computer model is passed on to the contractor, engineers, steel fabricators, masons, and any other subtrade on the job (Fig. 12). For most components of the building, the steel structure, precast concrete, metal cladding, and millwork, information is extracted directly from the three-dimensional computer model and sent to digital fabrication equipment, rather than by producing two-dimensional drawings.

The computer changes the system. We show the contractor the computer system and we show him a wall, built like the most difficult piece of the design. We also give him a disk that says 'give this to the stonecutter. We want 1,700 pieces of 
stone double curved, and 800,000 single curved, and 800,000 flat of this size.' And the stonecutter says, 'Oh that's not a problem.' He takes a look and says, 'Flat is one dollar, single curve is two dollars, double curve is ten dollars,' multiply that by the areas we give him, and he is happy. In fact we're doing a lot of the contractor's work. (qtd. in Friedman 53)

The complicated building industry is more than just architect and contractor

however. The legal, financial and insurance systems within the construction industry are resistant to change. "This being a system of legal responsibility, the lawyers say, 'Wait a minute, you're opening yourself to all kinds of lawsuits.' And the insurance company says, 'Wait a minute, you're doing something different. We don't know how to insure this if you're going to take more responsibility" (qtd. in Friedman 53).
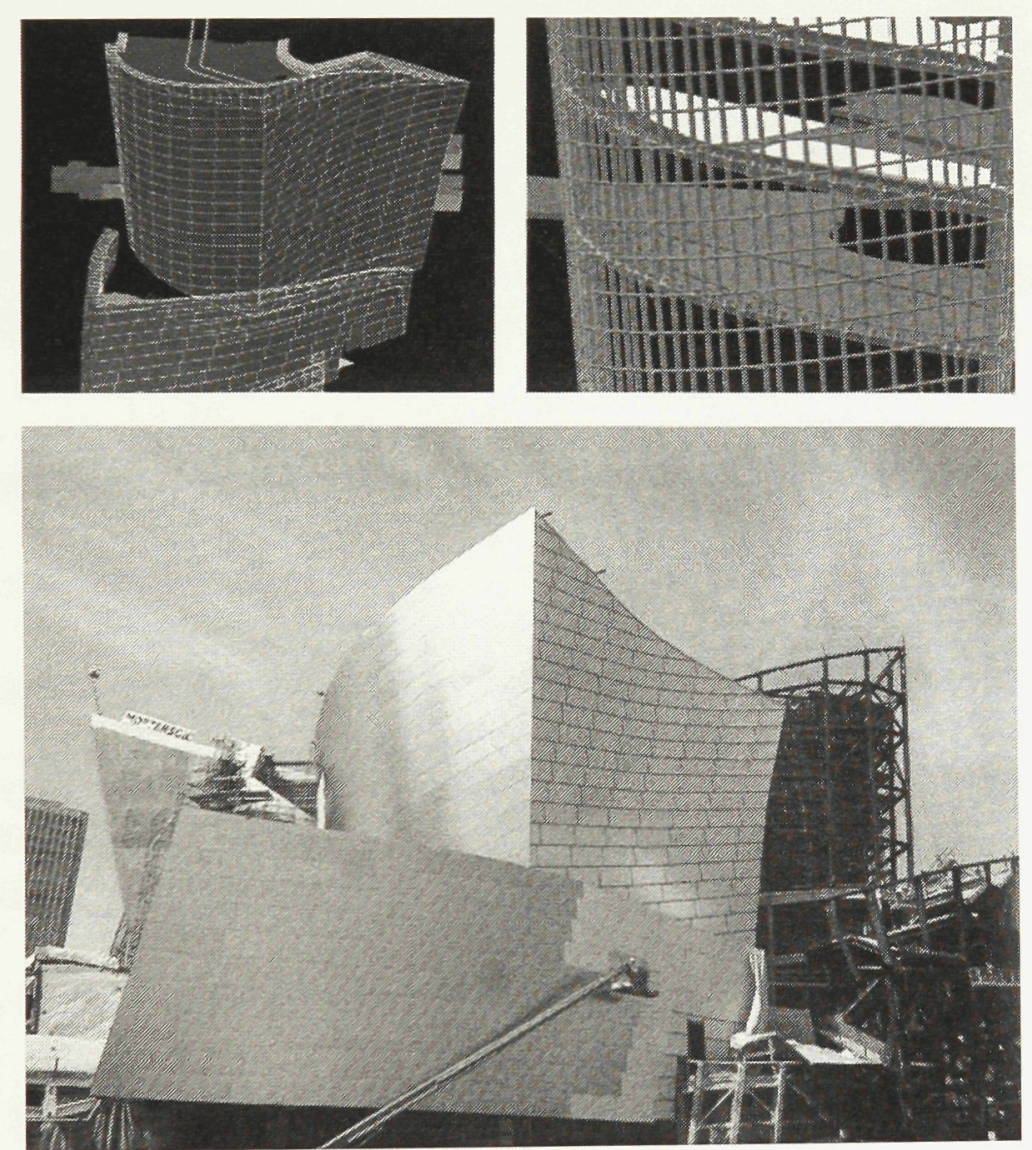

Fig. 11. Walt Disney Concert Hall photo and digital model, Architecture in the Digital Age: Design and Manufacturing (New York, 2003) 118. 


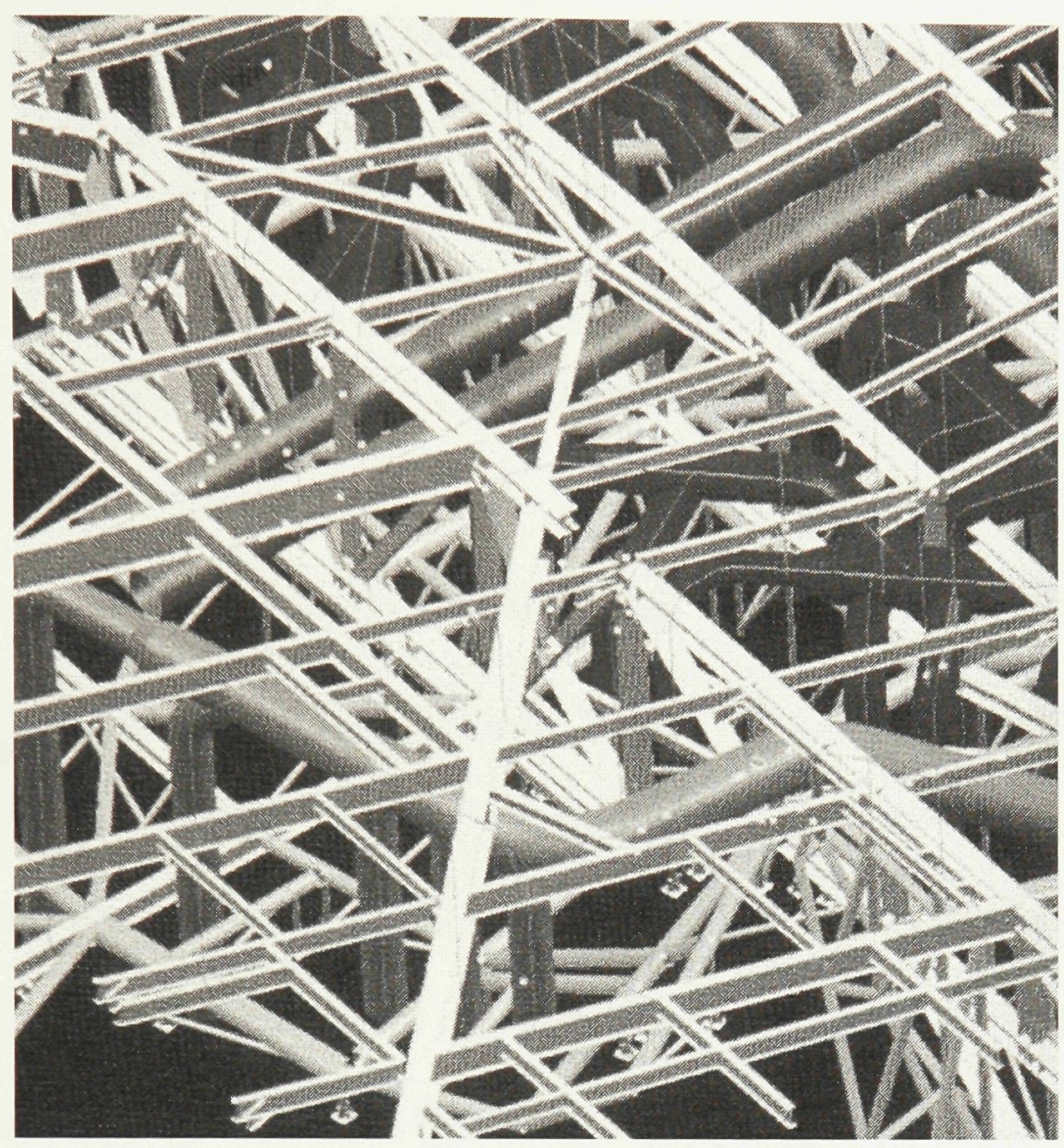

Fig. 12. Walt Disney Concert Hall digital coordination model, $\underline{\text { Architecture in the }}$ Digital Age: Design and Manufacturing (New York, 2003) 114.

Jim Glymph, who was instrumental in bringing CATIA to Gehry's firm describes the experience and process of working with contractors and various sub-trades with a three-dimensional model rather than two-dimensional drawings on two different projects. The first is the Experience Music Project in Seattle, Washington, a formally complex, sculptural building typical of Frank Gehry's designs (Fig. 12). During the construction, contractors and trades collaborated and shared information through the computer model, eliminating the use of shop drawings for portions of the building.

[...] since we had no time, it would be much faster if we did not bother with shop drawings. We had three different trades working out of the same computer model without shop drawings, fabricating their components directly from the computer model, and everything fitting together on the site with rather complex geometric forms without mock-ups. That part of the building was built in just four weeks. At that point, everybody understood 'it'-the contractors in the field 
understood 'it'-there were no drawings and that was the least expensive way to do the project. That was a very important transition in the project. What made it possible was not the software so much-obviously, that is the tool-but a cultural change that took place on the building site. (Glymph 110)

One of the reasons "it" is the least expensive way is the hidden costs of shop drawings. Fabricators pay draftsman to do the drawings before work begins on actual fabrication. Essentially, there is a second set of drawings prepared for the project by the fabricators. According to Glymph the cost of shop drawings can be exceedingly high. "If you look at the amount of money invested in shop drawings for a large-scale project, it far exceeds the architectural and engineering fees" (qtd. in Cocke 124).

The second project, where Gehry's firm experienced resistance to working with a three-dimensional model for the steel structure, was the Disney Concert Hall in Los Angeles, California (Fig. 13). Even though the Experience Music Project was constructed from digital construction documents prior to this project, because of the local construction milieu, the same streamlined construction process was not achieved for the steel structure.

Part of the problem was that the group was working in the litigious environment of Southern California, with a construction tradition that made the group reluctant to accept the notion of collaboration as it occurred in Bilbao and Seattle-that they could build on each other's models. People would start over or go backwards; they would avoid taking part in the collaborative process that we had working so flawlessly five years earlier in Bilbao. Even though there were advances in the way we did the modeling, advances in the software and in $\mathrm{CAD} / \mathrm{CAM}$ technology, traditional claims building attitudes made collaboration extremely difficult. That cultural barrier to the sharing of information and ideas is the really difficult issue. (Glymph 113)

Gehry's projects not only are case studies in the use of digital modeling and fabrication in the design and construction of buildings but also expose many of the issues 
associated with the litigious and adversarial relationships that exist on construction sites and provide an example for new ways of practicing architecture.

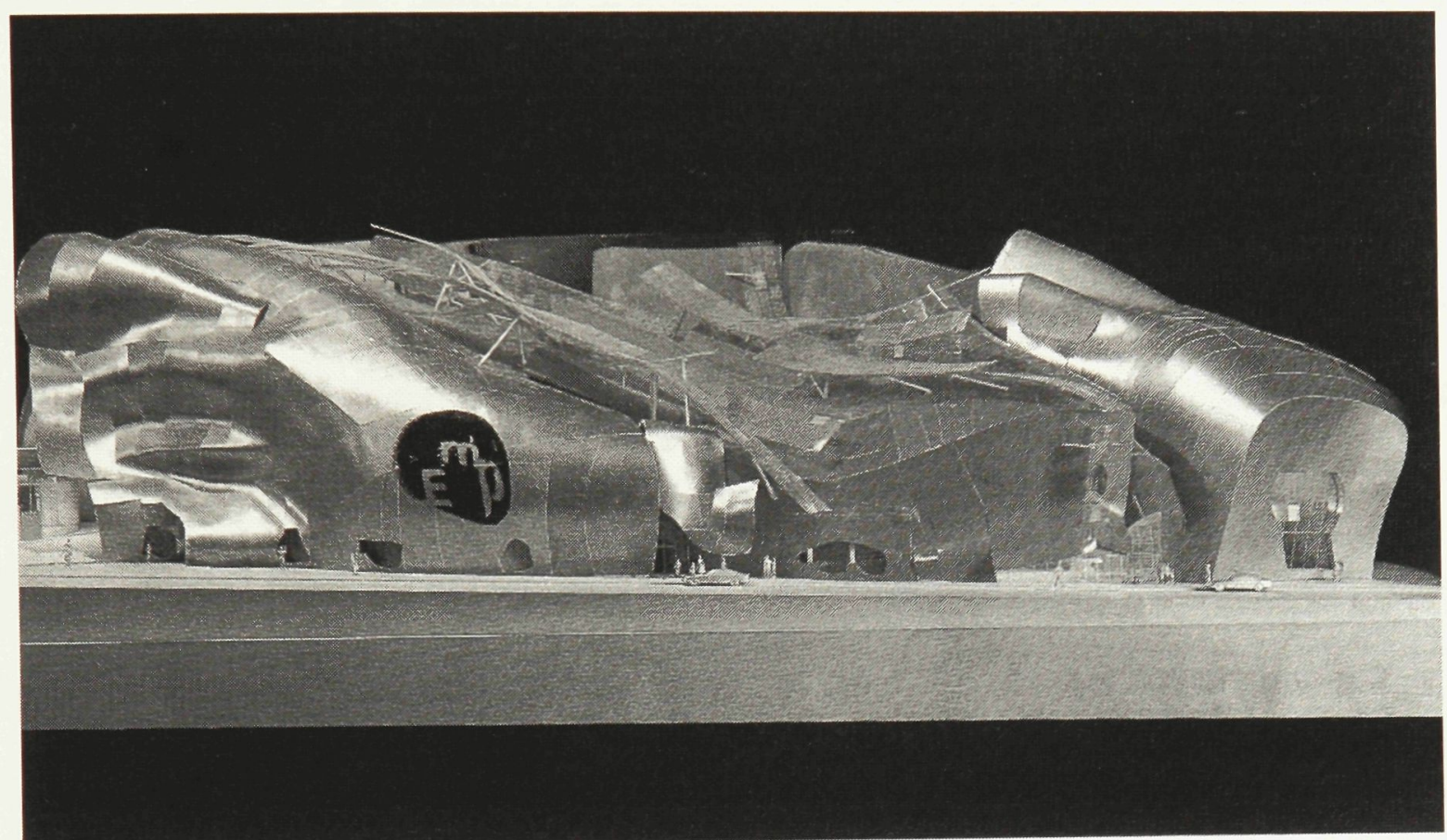

Fig. 13. Final design model for EMP, Gehry Talks: Architecture + Process (New York, 2002) 201.

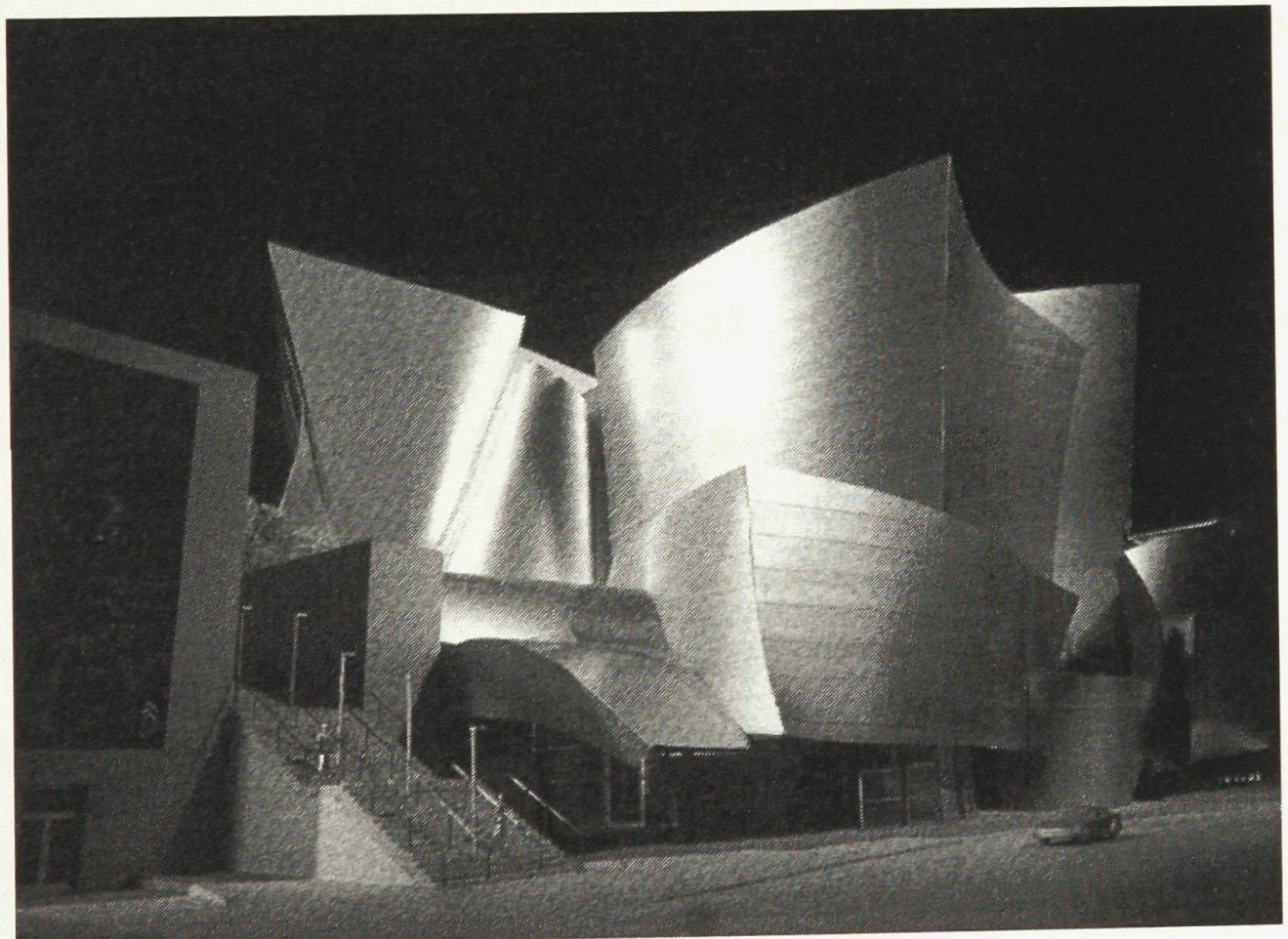

Fig. 14. Walt Disney Concert Hall, Architecture in the Digital Age: Design and Manufacturing (New York, 2003) 103. 


\subsection{William Massie}

Architect William Massie, Architect-in-Residence at Cranbrook Academy of Art, explores the use of $\mathrm{CNC}$ technologies in the production of architecture and his practice often engages in the construction of the projects. He recognizes the implications of digital fabrication technologies in the way architects practice, believing that "this technology not only eliminates the distance between 'virtual' architectural hypotheses and the physical test of construction, but also forces us to examine our roles as architects in a condition allowing greater potential input into the processing of building construction" (Massie 55). Two projects that Massie's office both designed and partially built, the Big Belt House in Montana in 2000 and the Playa Urbana installation at PS1 in New York in 2002 are examples of architecture in this new mode of practice.

The first clue that the Big Belt House has been designed and constructed in this new paradigm is the fact that no construction documents were produced for this project. The majority of the house components were created through the use of digital fabrication technology. The structural system of concrete was poured into formwork of rigid foam that was milled by a CNC router in Massie's office. The formwork was test assembled in the office then disassembled and transported on site where it was reassembled by Massie and his office. The curving columns and beams of poured concrete would have been cost prohibitive if it had been constructed with traditional methods of formwork built on site by carpenters. Smaller components of the house were also custom fabricated, including sinks and windows. The exterior cladding of compound curving walls are made up of laser cut steel arcs and PVC piping. The steel arcs were cut with a series of circular holes 
to allow the PVC pipe to be threaded through creating a substrate that was subsequently finished with spray on insulating foam and aggregate.

At Playa Urbana, Massie again used PVC pipe threaded through laser-cut metal arcs, leaving the pipes exposed this time to provide varying degrees of enclosure and shelter from the sun. Reflecting and wading pools were made by coating CNC-milled rigid foam with plastic, making the rigid foam a part of the construction instead of a formwork. During the design, the maximum deflection of the PVC pipes was measured and entered as a design parameter into the software to ensure that the curving forms of the installation would not exceed the capabilities of the piping.

Although the sculptural forms of the Big Belt House and the Playa Urbana installation are considerable accomplishments, especially for design-build projects, the most innovative aspect of the design is the ubiquitous "puzzle piece" detail seen at various connections (Fig. 15 and Fig. 16). This detail allows for quick assembly on site and ensures that the construction can only take place in one way, but is only viable because it is directly integrated into the fabrication of individual components. Massie's ability to embed these details into the building through computer modeling and CNC machining is what makes the detail innovative. The "puzzle piece" in the formwork of the Big Belt House allows the individual pieces of formwork to lock together without any additional fastening. For the Playa Urbana project, the "puzzle piece" detail adds a negligible cost to cutting the steel, because it is a curved rather than straight cut, but significantly reduces work on site by allowing welders to quickly lock pieces together and weld, facilitating a more quickly fabricated and higher quality connection. If this detail was described through a working drawing, it would only add cost or negate the 
benefits of quick assembly on site by adding labour costs in the original fabrication of the formwork and steel sections.

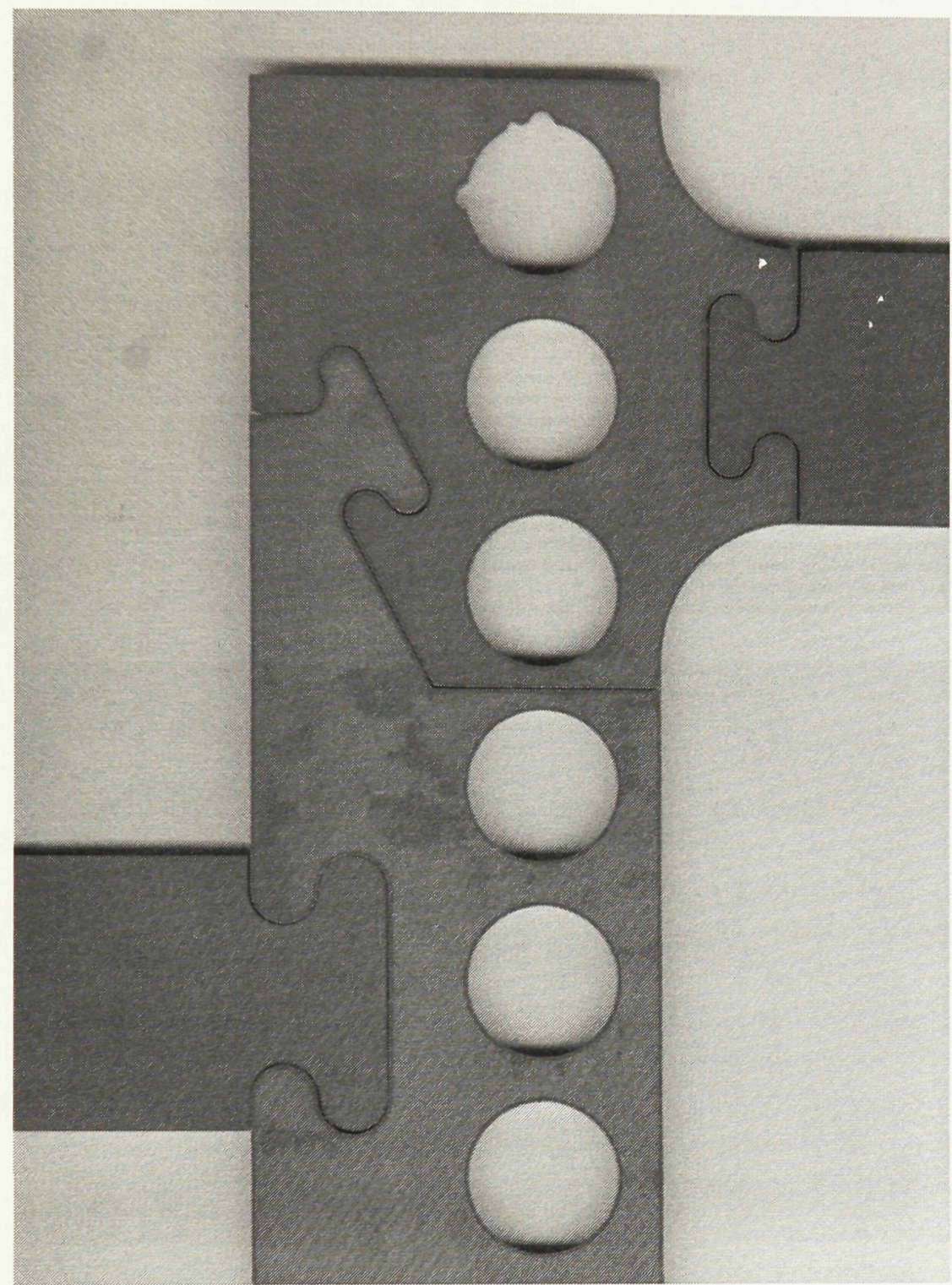

Fig. 15. Puzzle piece with joints laser-cut in steel - holes are cut to admit pvc piping, Praxis: Journal of Writing + Building 6 (2004) 18. 

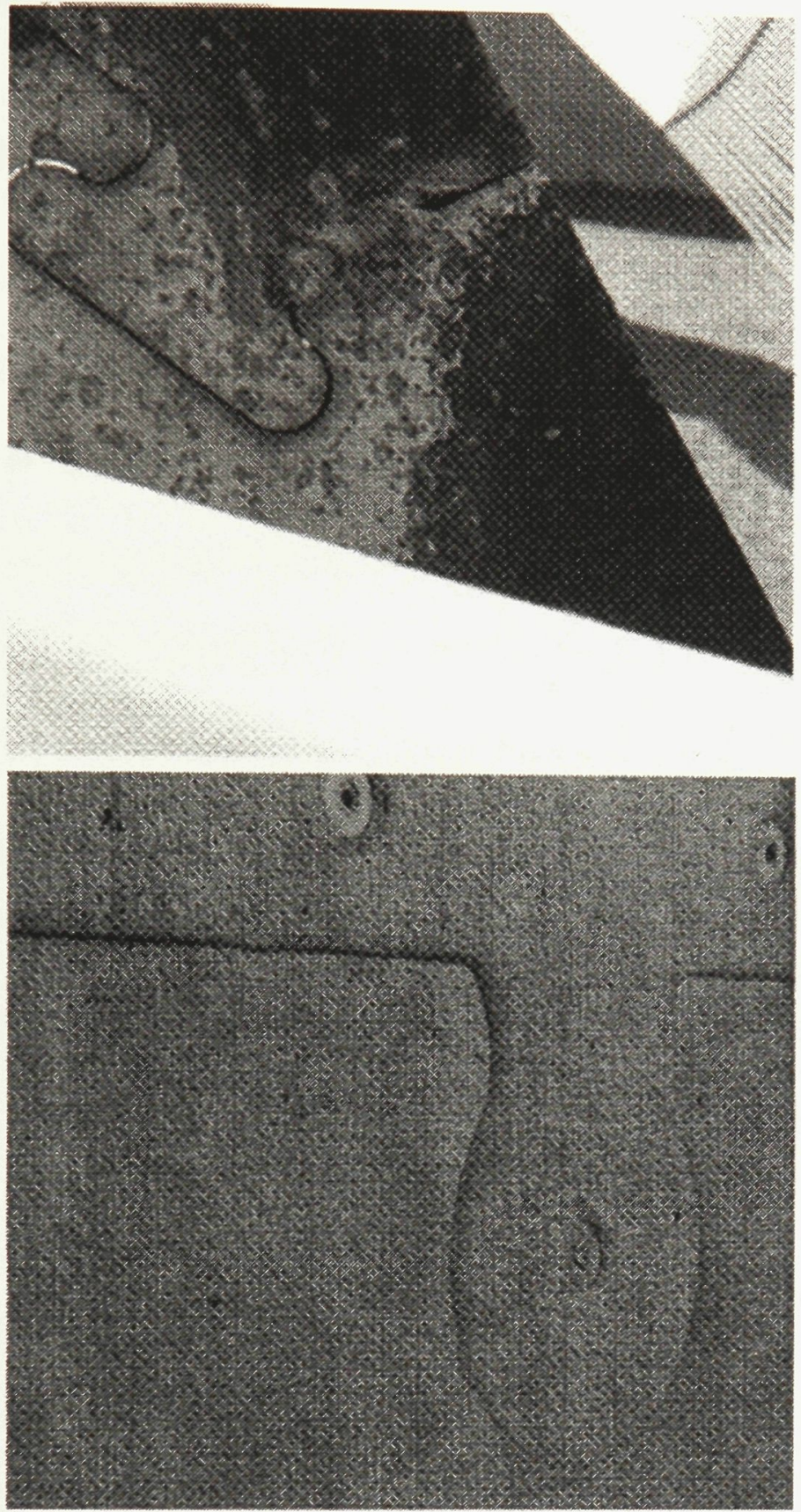

Fig. 16. Puzzle piece joint details, top Playa Urbana, bottom Big Belt House, Praxis: Journal of Writing + Building 6 (2004) 19. 


\section{Design Proposition}

\section{$5.1 \quad$ Context}

The post-industrial landscape of Detroit's eastside neighbourhoods has become a strangely rural one (Fig. 17). So many houses have been demolished or burned or just fallen over that vacant lots run together to form urban prairies (Fig. 18). Some neighbourhoods have taken up urban farming as a community-building activity, a small source of income and way to keep vacant lots from being eyesores. Urban farming is an excellent interim use of land, but the city wants something that will be a larger contributor to taxes and a spark for the economy-residential development.

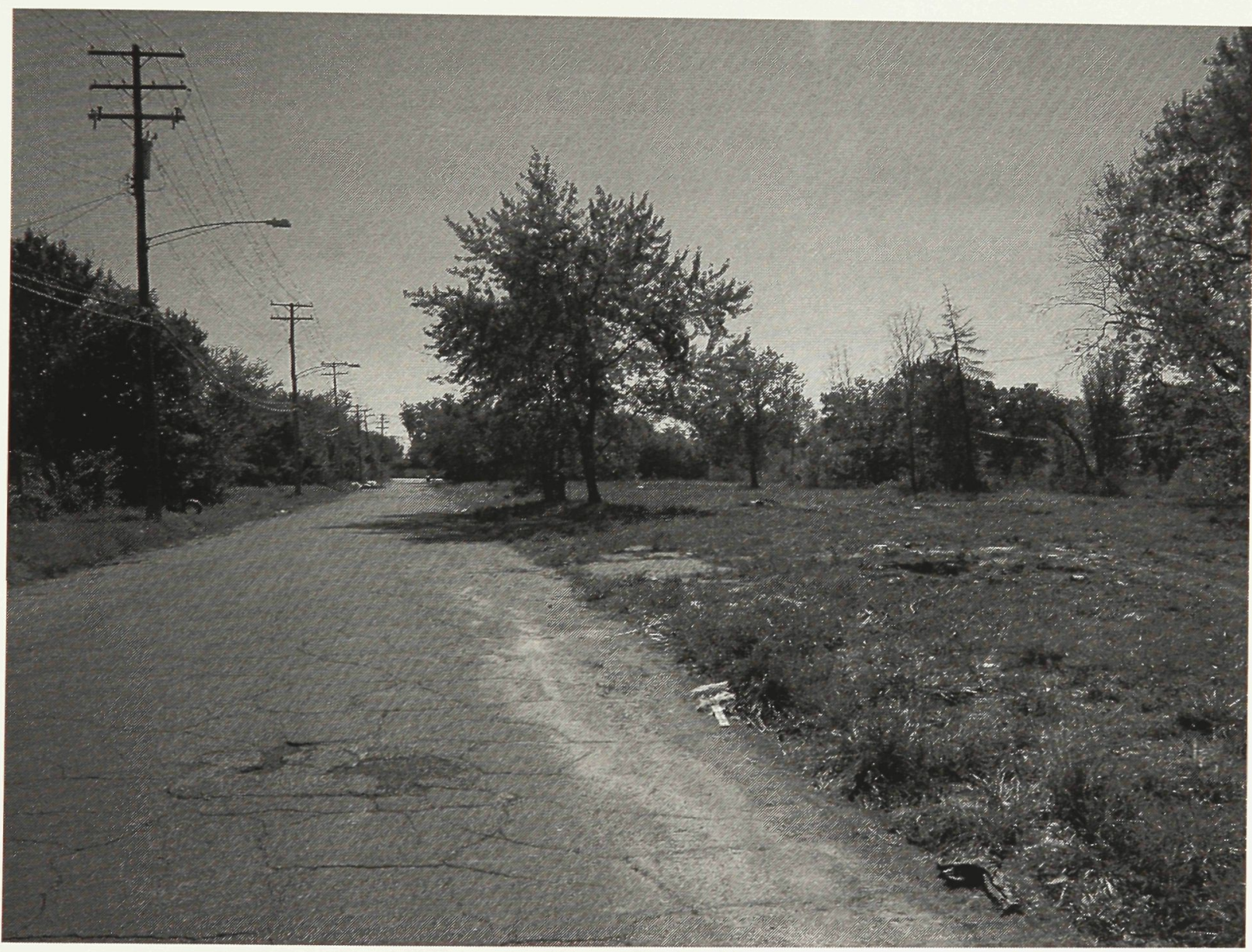

Fig. 17. The strangely rural landscape of eastside Detroit. 


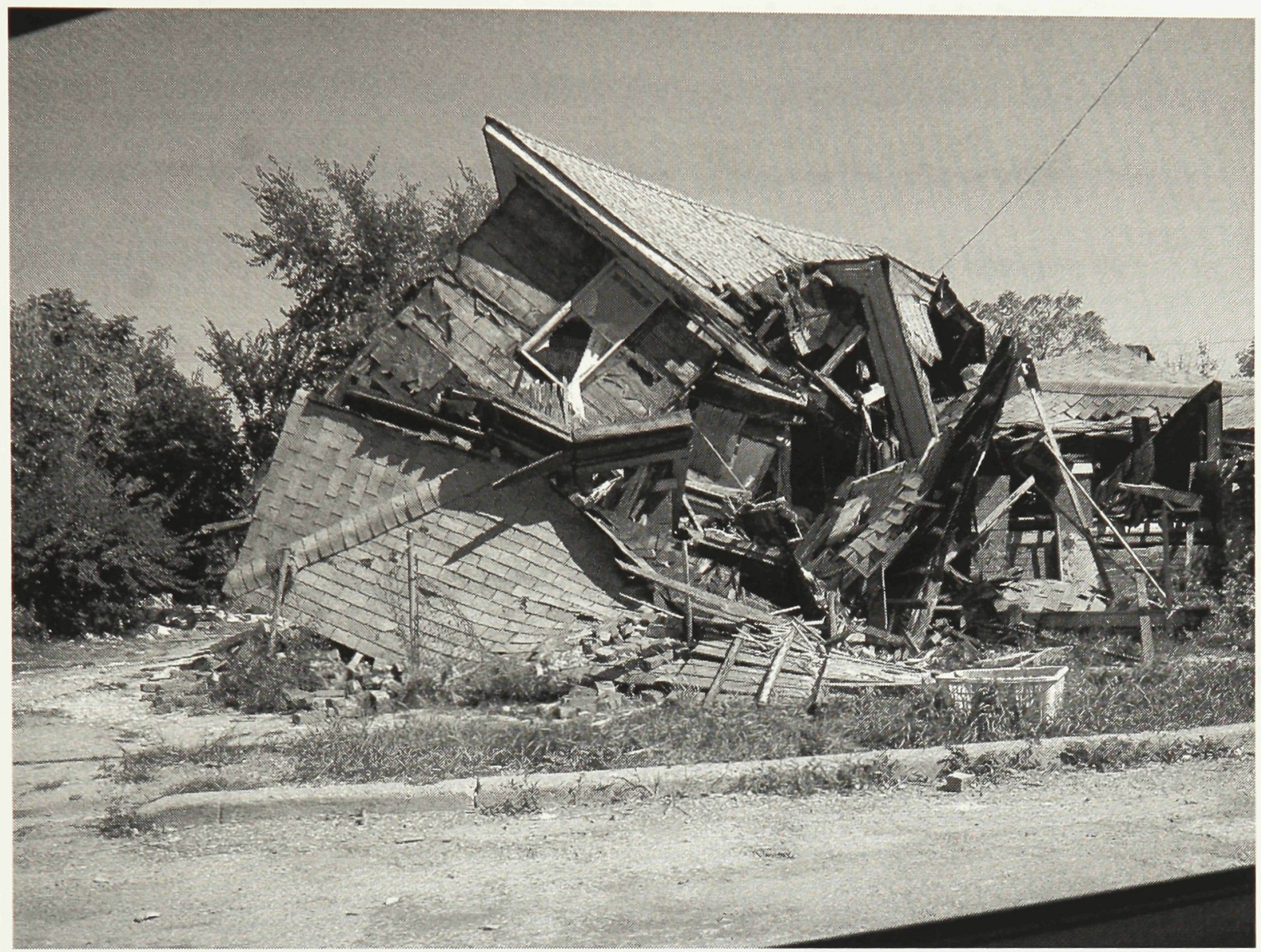

Fig. 18. Collapsed house.

The development the city seeks is called the Far Eastside Project. It is the most ambitious urban redevelopment the city has undertaken. The city has invited developers to submit proposals which will spare viable homes rather than demolish everything and start with a blank slate. The new construction will be integrated into the existing neighbourhoods. The Far Eastside Project is a 1,200 acre area that will see the construction of more than 4,000 houses over eight to 12 years on Detroit's east side (Rose). The new homes will range in price through a mix of market priced homes and subsidized homes, with the goal of developing diverse neighbourhoods.

For most North American cities the distinction between urban and suburban is a blurry dematerializing mess of sprawling asphalt and strip malls. In stark contrast, 
Detroit's city limits are an uncanny, exaggerated demarcation of urban/suburban, poor/rich, black/white. Essentially, Detroit's entire city limit is a boundary condition,

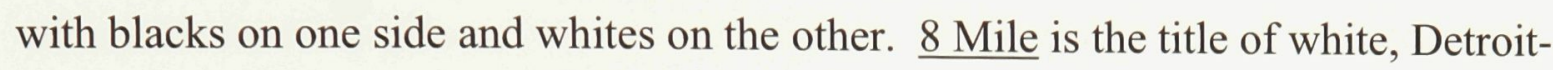
rapper Eminem's movie about growing up in black Detroit and the segregation symbolized by 8 Mile Road, Detroit's northern boundary with the suburbs. Mack Avenue is another one of these stark boundaries. It divides Detroit from the affluent Grosse Pointe Park. The difference between the urban fabric on the Detroit side of the street and the Grosse Pointe Park side of the street is evidence of the disparity between Detroit and the suburbs. Thriving businesses and restaurants on tree-lined sidewalks with planters and benches are mirrored by boarded up shops and crumbling concrete overrun with weeds (Fig. 19).

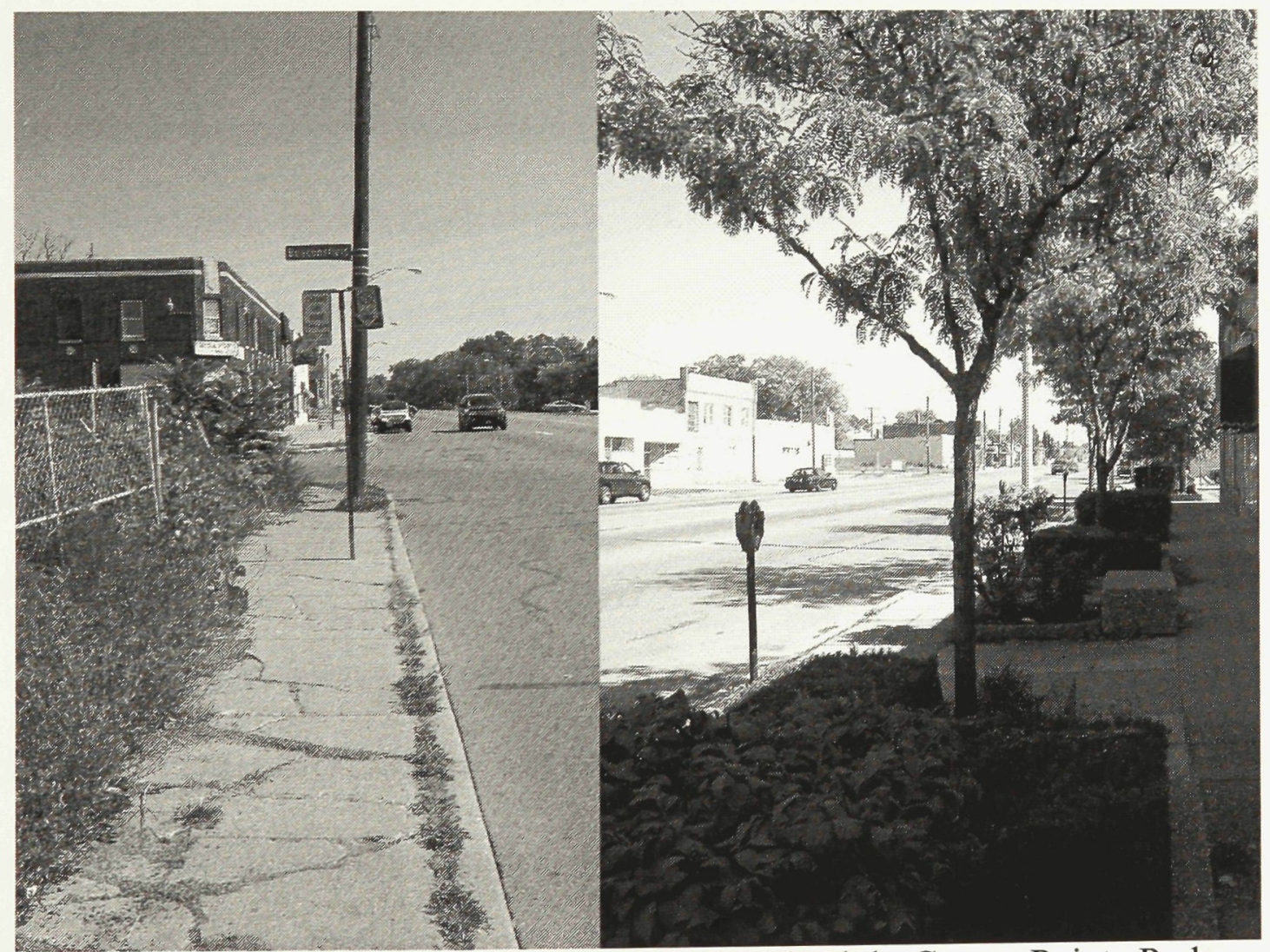

Fig. 19. Opposite sides of Mack Ave, left Detroit, right Grosse Pointe Park. 
A few residential blocks, bounded by Mack Ave to the south and Alter Rd to the west (the eastern most boundary of the Far Eastside Project), are chosen as the site of the affordable housing project (Fig. 20 and Fig 21). There has already been some new affordable residential construction in the area along Alter $\mathrm{Rd}$. This new housing recently constructed, called Morningside Commons development is highly repetitive, unattractive, and constructed with inexpensive materials not likely to age well (Fig. 22 and Fig. 23). The likelihood of this housing attracting residents of varying incomes and backgrounds is low. Ironically, the same fundamental criticisms leveled against the post-war modernist projects could be used here. This neighbourhood is of an extremely homogenizing nature both formally and demographically. The houses are nearly identical with superficial variation in colour and material. A criticism of many post-war public-housing projects was that of a homogenous population of low-income residents concentrated into one area. The houses in the Morningside development fall into the same trap. This development also follows many postmodern or New Urbanist tenets. The houses are connected to the city grid, the entire development is of a pedestrian scale, and aesthetically the new houses have a "traditional" appearance. Despite the adherence of these New Urbanist tenets Morningside Commons could still be criticized in the same way as the modernist projects of the 1950 s.

From a developers point of view, Morningside Commons is understandably built cheaply because of its purpose, that of affordable housing. In order for the houses to be sold and rented at low prices construction costs must remain low. One of the results of this strategy is the elimination of "extras" like large porches. A cursory examination of the existing building stock shows the prominence of large front porches, a gathering place 
for families. Strategies to lower cost are fundamentally changing the way people will live in their homes. As well, suburban housing strategies being employed, like attached side-garages, are completely alien to the existing neighbourhoods (Fig. 24 and Fig. 25). The surrounding neighbourhoods have alleys with garages located behind the house. What would normally be considered non-traditional families actually make up the majority of households in the area (Table 1). Suburban home types for more traditional families are not the most suitable type for this area. Although superficially similar to existing houses, these new houses, which have become the dominant housing type in the area, are successful in their role as affordable housing in that they have been purchased by low-income families. Unfortunately, this is the only role they perform successfully. Table 1. 2000 Census Profile for Jefferson/Mack Subsector

\begin{tabular}{|c|c|c|}
\hline Households & 2,041 & \\
\hline Average Household Size & 2.86 & \\
\hline Population in Households & 5,838 & \\
\hline Family Households & 1,248 & $61.15 \%$ \\
\hline Married Couple Family & 295 & $23.64 \%$ \\
\hline Female Householder Family & 804 & $64.42 \%$ \\
\hline One Person Households & 640 & $31.36 \%$ \\
\hline
\end{tabular}

Source: U.S. Census Bureau; 2000 Census; Summary File 3 


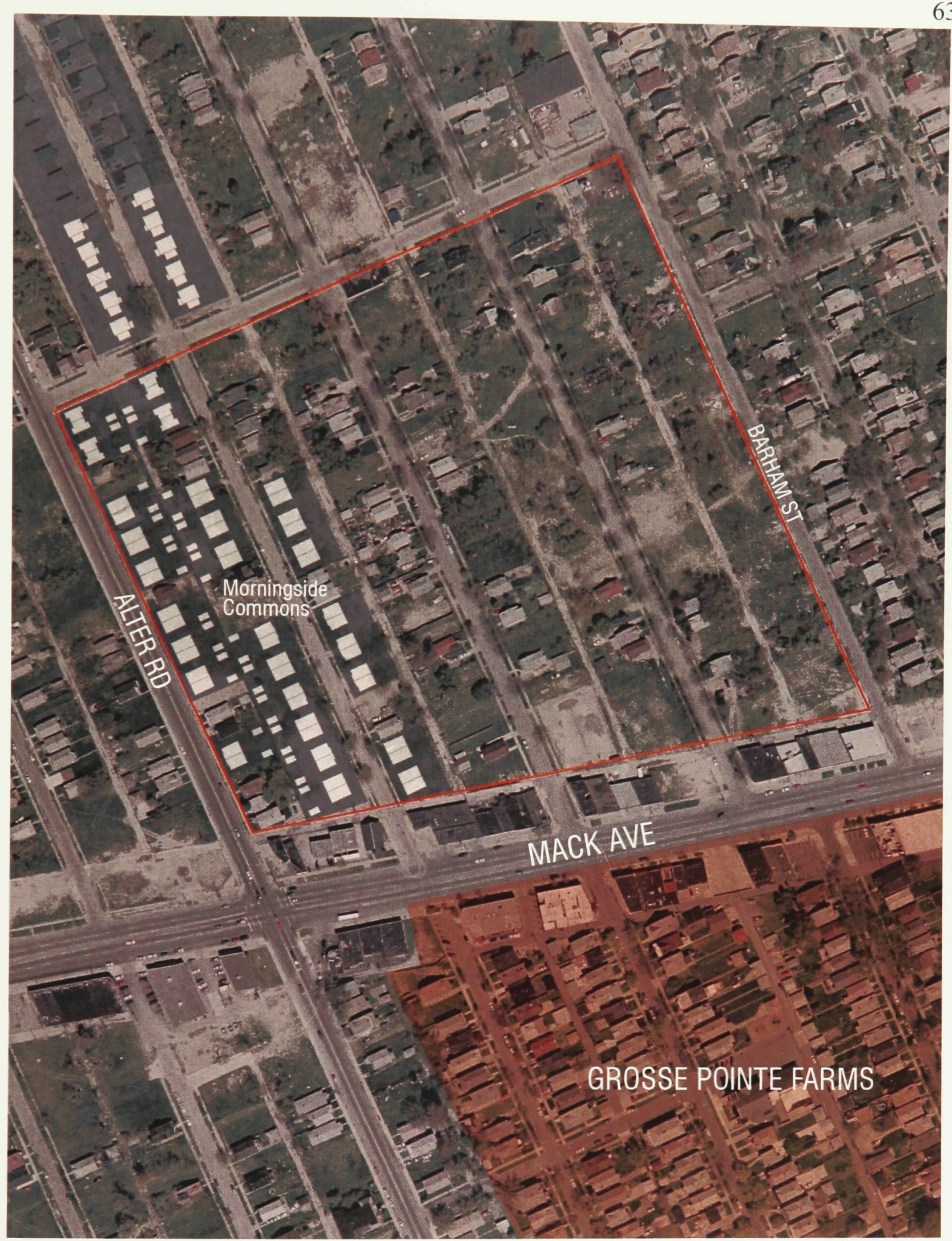

Fig. 20. Aerial composite, (site defined by red boundary). 


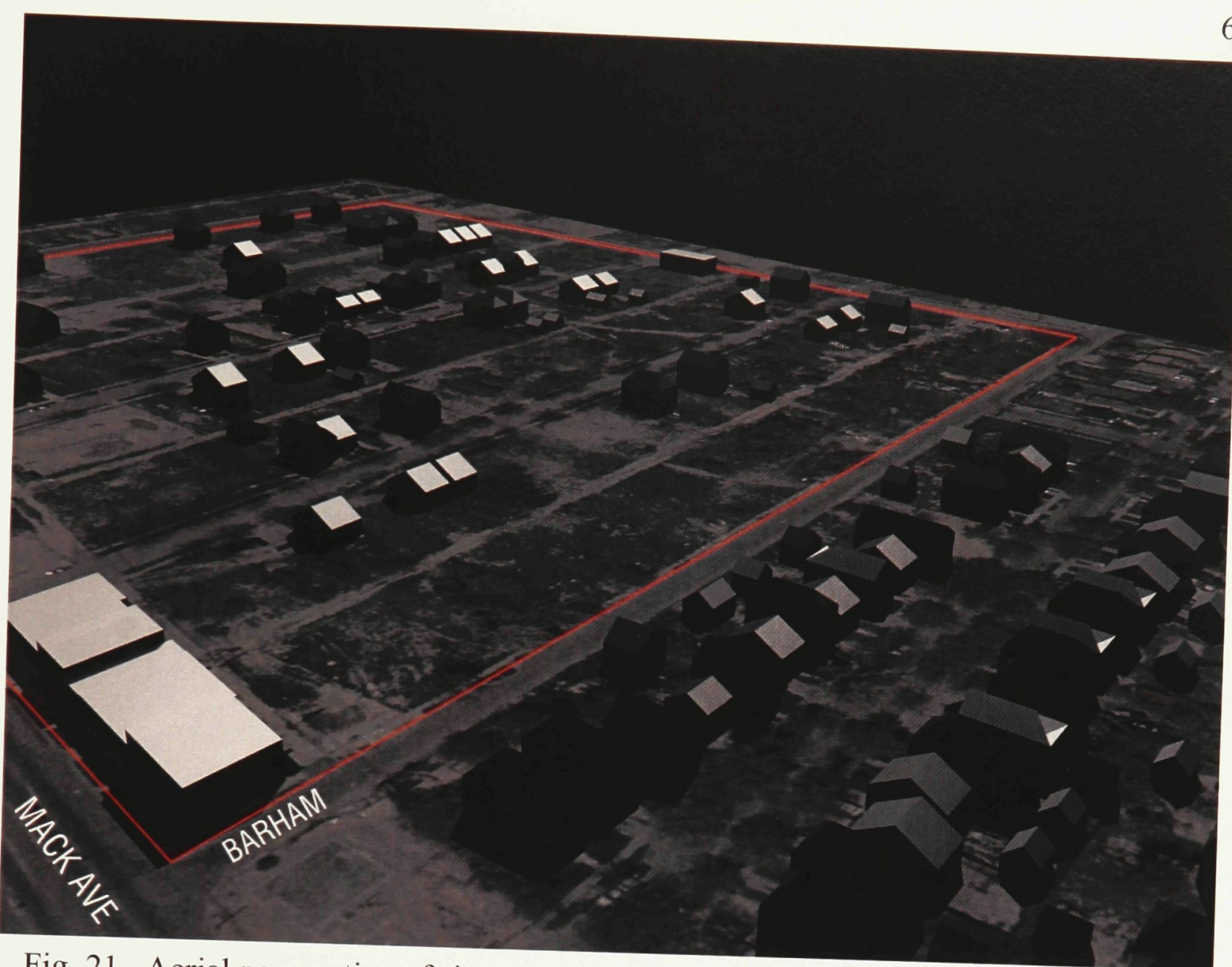

Fig. 21. Aerial perspective of site prior to construction of Morningside Commons.

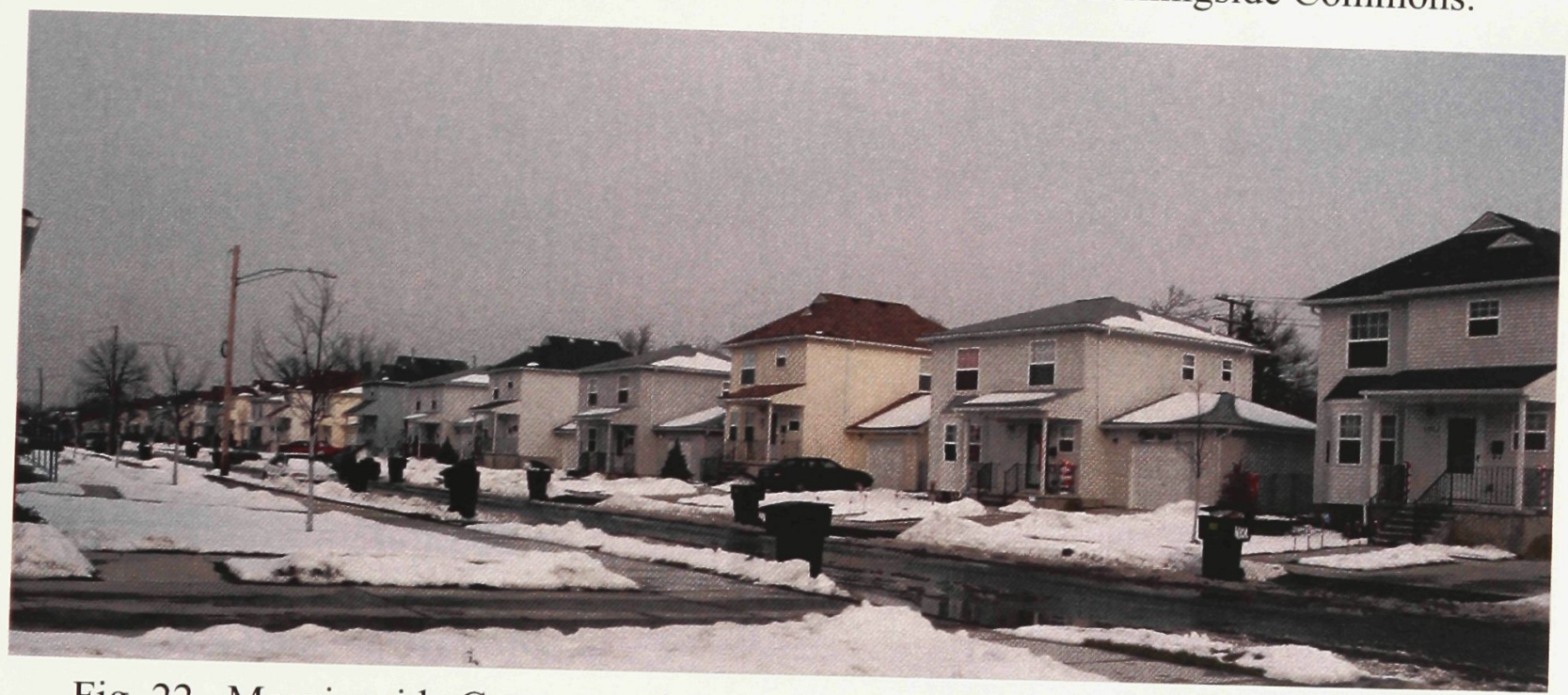

Fig. 22. Morningside Commons detached houses. 


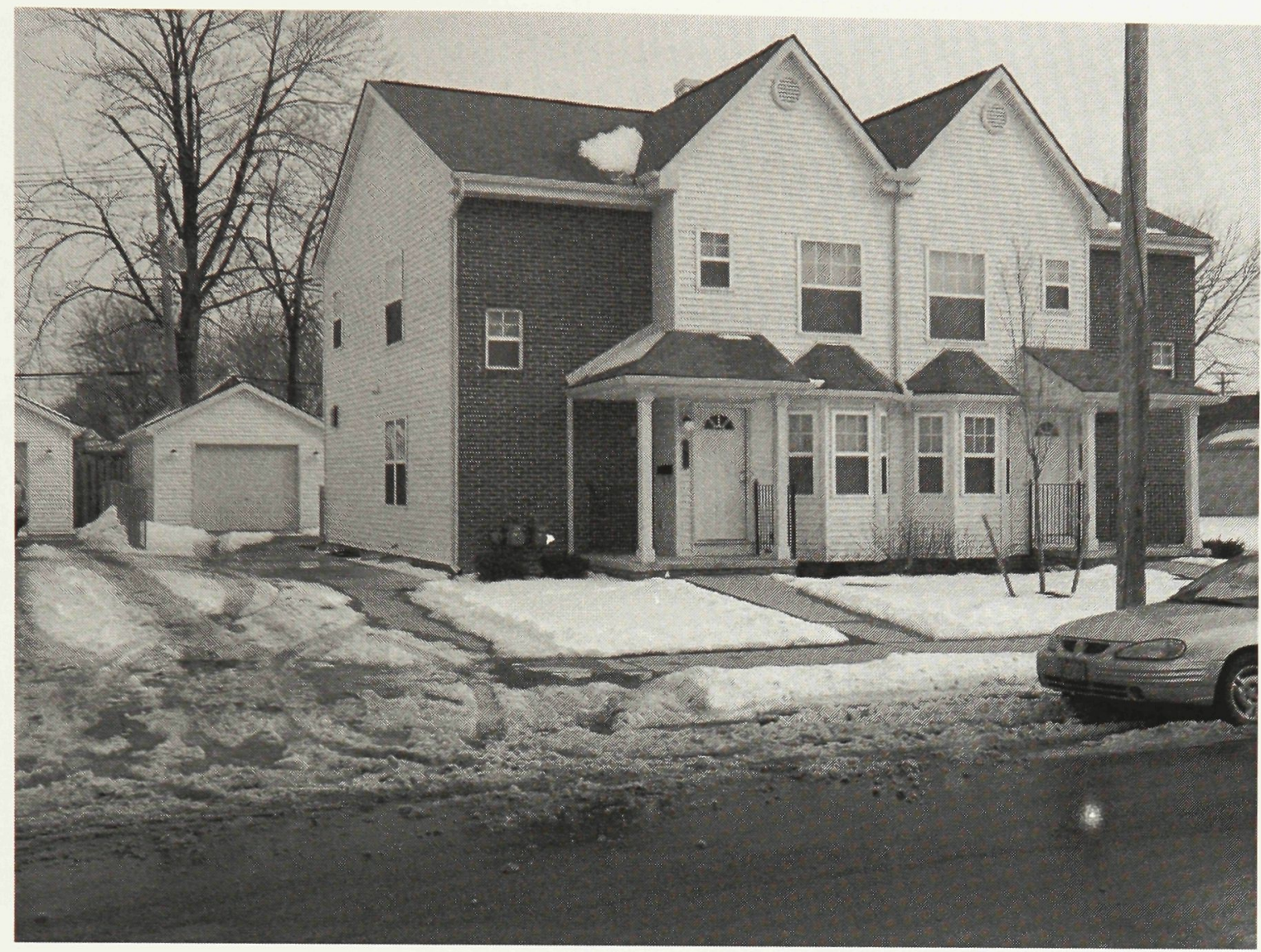

Fig. 23. Morningside Commons semi-detached townhouses.

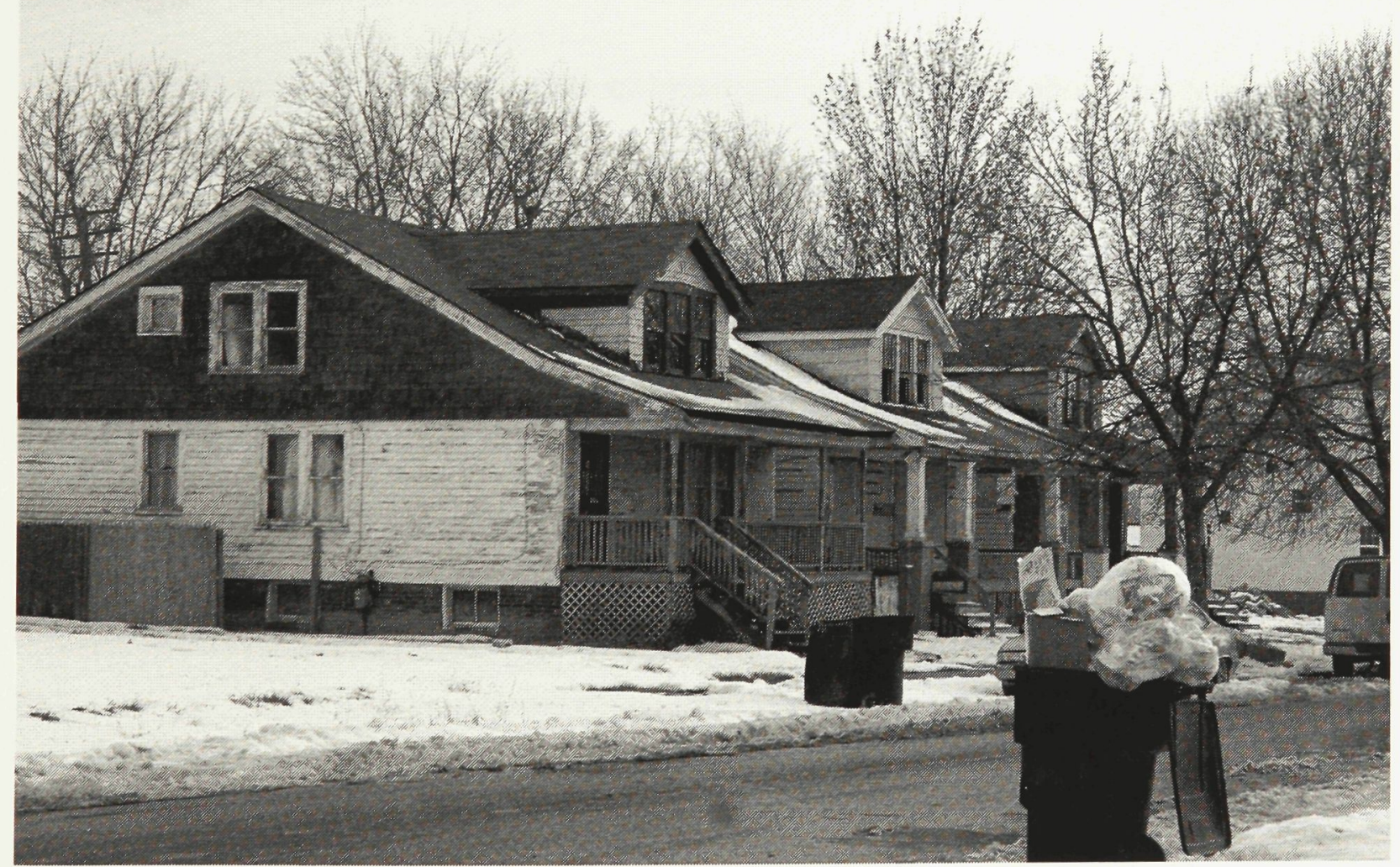

Fig. 24. Typical "bungalow style" houses on the eastside of Detroit. 


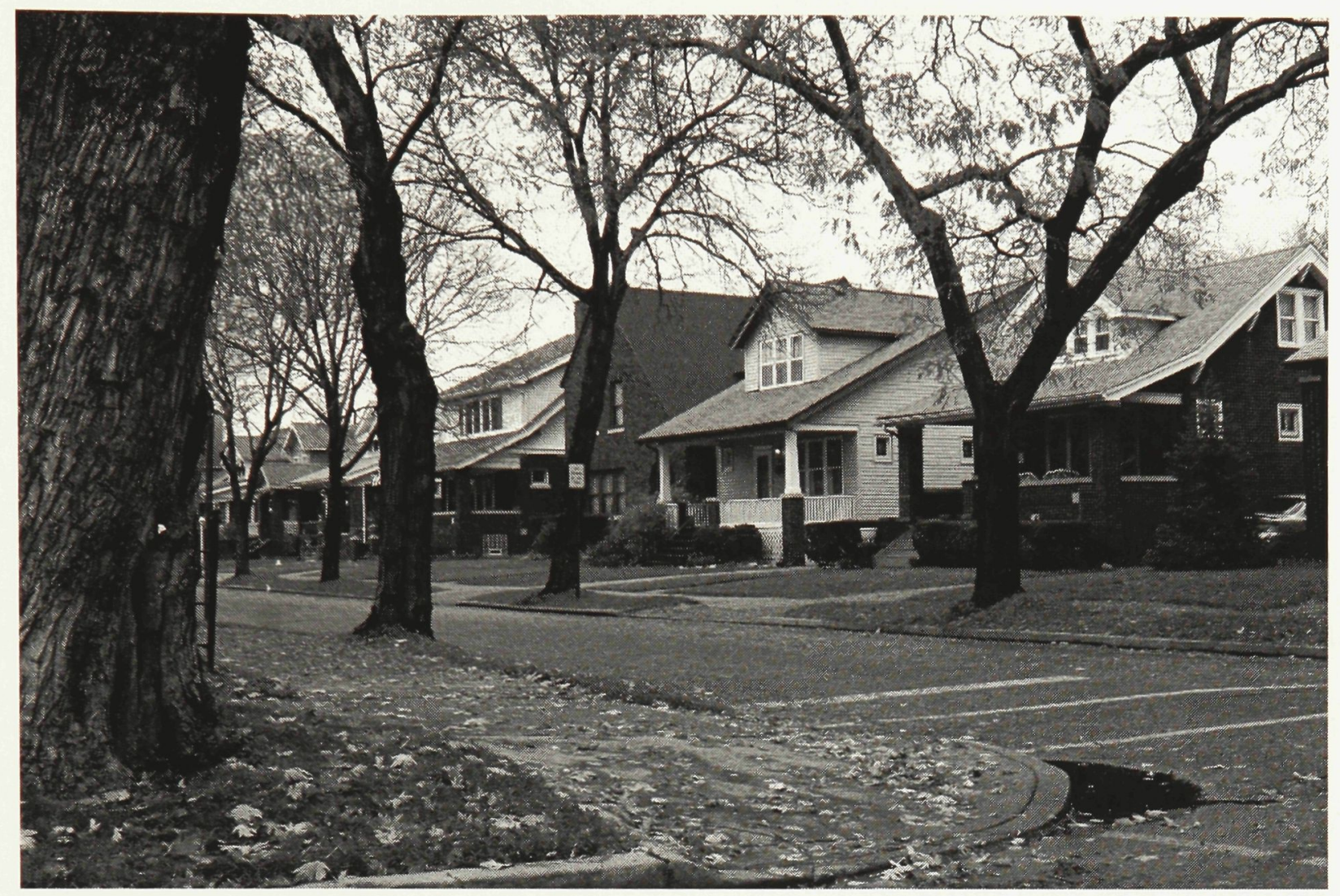

Fig. 25. Typical "bungalow style" houses in Grosse Pointe Park.

\subsection{Design}

There is a crucial, broad, non-architectural decision made about the design proposal that affects the overall design. This decision is that the homes will be owner occupied, rather than rentals. Homeownership for low-income families has several benefits over renting some, obvious and others not necessarily so obvious. The American dream is deeply imbedded in homeownership, but homeownership is more than just a symbol of status like the automobile or the white picket fence. "For most of the past 40 years, home ownership has not only been a symbol of wealth, but also the most important actual wealth most American families accumulated" (Forrest and Murie 92). This statistic is important, but there are often questions whether small affordable housing can achieve the same wealth accumulation. Indeed there are also statistics that show "modest 
owner-occupied housing may represent as good an investment as more expensive homes. This is good news for lower-income, younger and minority families [...]" (Forrest and Murrie 96). The benefits are also inter-generational. North Americans who grow up in owner-occupied homes often do not realize the financial benefits that they unwittingly receive from growing up in owner-occupied homes. There are "substantial benefits for wealth accumulation, not just for a given set of households but also for their children" (Retsinas and Belsky 423).

Another benefit of home ownership highlights the inconsistencies of government housing policies. Since the federal government has virtually ceased funding affordable housing, homeownership can be seen as another way to receive government funding. "Homeowner tax deductions-that permit homeowners to write off from their federal tax bill the interest they pay on mortgages, property taxes and capital gains tax realized when selling a house - will cost the federal treasury an estimated $\$ 78$ billion in lost revenues. That total is almost twice as much as the government will spend on programs for wouldbe homebuyers, the homeless, low-income and elderly renters and public housing tenants combined" (Forrest and Murie 97).

The organization of the new proposed lots is therefore based in part on the fact the new housing will be owner-occupied. The lots of the future homes are virtually worthless from a purely monetary perspective. Residential lots in Detroit can be purchased for a few hundred dollars, and more often the city will give lots away to developers. Ironically, this is also a major strength. For someone building a home, free land is a considerable asset toward lowering costs. For this reason and the sheer abundance of vacant land, in this proposal, each owner of a new home would also receive 
a vacant lot. In the future, the lot could be sold purely for a financial gain, or it could be passed on to a child who has grown up and is looking to build their own home, or it could simply be kept as an urban farm plot. The recently constructed affordable housing has restrictions on the sale of the home within the first five years of ownership. This same restriction would apply to the proposed new homes and the associated vacant lot. Not every person will have the time nor desire to work the land of an entire second lot as a garden. In order to keep the vacant lots from becoming overgrown weed beds, most will be used to grow wheat, a roundabout way to acquire straw.

Up to this point urban farming crops are usually grown for sale at a market or for personal consumption. Small plots are all that is required and are easily manageable. On the east side of Detroit, however, there are so many vacant lots that large swaths of land could be utilized to grow wheat, which in turn could be used as straw bales for new homes. Within the new development two contiguous strips of lots will be utilized to grow wheat which will be harvested and then the remaining straw can be bailed for use in the construction of homes.

Of the proposed 75 new houses 15 of the associated vacant lots will be integrated among the new housing and the other 60 vacant lots will be contained within the two contiguous strips of wheat (Fig. 26). In this way the land can be put to productive use and avoid becoming another vacant weed bed without the dependence constant attention by residents. In addition two smaller plots of land will remain as dedicated community gardens, after all the vacant land is used and a larger urban farm based on the model of Earth Works Garden already in Detroit. It supplies produce for a soup kitchen, food bank 
and teaches area school children about nutrition and organic agriculture (http://www.earth-works.org/).

There are two main issues related to affordability that the design addresses. First the design needs to be affordable to purchase, and second, it should ideally be affordable to occupy. Since the new homes will be owner occupied, in order to lower costs the construction is designed to take advantage of sweat equity. Sweat equity can be defined as owners or a community of owners putting in hours of labour themselves to avoid paying someone else to do the work. Most of the construction would be performed by owners of the house, or community organizations already active in the area, (http://www.warrenconner.org/projects/rci.htm) or a group like Habitat for Humanity (owners working with volunteers). This means that the majority of construction needs to be accessible for the average person. The construction of straw-bale homes is an excellent example of sweat equity, but more than just saving money; the construction is a community building and environmentally-friendly activity. Volunteers and other owners gather to build a home and create friendships and relationships in the process.

The design of the houses is based on a simple plan, since excavation and foundation work cannot easily be influenced by CNC fabrication. A conventional foundation is topped by a typical light frame floor structure. From the floor up, the majority of construction will be completed by the residents. In order to create houses that will enable the average person to construct, building components with details that make for easy assembly have been utilized. Vertical supports made up of CNC cut plywood and dimensional lumber, fit into slots cut into the plywood sub-floor. The house is essentially a post-and-beam construction that is infilled with straw bales. A curving roof 
and a sectional form that would be considered non-standard for developer homes is designed with a combination of CNC cut plywood and engineered lumber. The plywood provides a connection between roof members that facilitates easy construction for residents.

Three-dimensional contouring by CNC mills or routers is more costly than simple two-dimensional cutting (appendix). The components for the houses are cut by twodimensional CNC cutters from plywood sheets. Each sheet is cut leaving a tab between the piece and the waste plywood making shipping to the site easier. After arriving on site, the small tabs are cut out and the components removed. All of the components have their specific part name and sequential number fabricated into it.

The second aspect of affordability, making the home affordable to occupy, is accomplished by making it economical to heat and cool. The simple design is typologically similar to the ubiquitous bungalow-style houses of the area. The small size in its self keeps heating and cooling costs low, while the straw-bale walls provide an enormous amount of insulation. The sectional qualities of the roof allows for both passive heating and cooling. Sun entering through the skylight warms the thermal mass of concrete, and the same skylight allows for warm air to exit, creating a stack effect cooling the house. The curving roof allows solar panels to constantly catch the sun's rays as it moves through the sky, providing energy for the home.

A fundamental difference between the proposed homes and those built by developers (and most consumer products for that matter) is the connections the house makes to its own production and surrounding environment. With the development of mechanized factories and mass production, the production of goods has become a 
"virtually invisible activity" (Calicott 33). This is also true of the developer homes as building products arrive from unseen factories and the house itself is essentially a product to be purchased. By including a participatory construction process and using straw-bale construction, with straw which is grown in the near vicinity, there is a close connection between the production of the housing and its physical and social environment.

In addition to making it economical, the solar aspects of the house also connect the residents to the environment more strongly than in conventional houses. The idea of urban farming in Detroit has established a connection with the production of food and therefore to the physical and climatological environments not normally associated with urban living. This link is experienced in the house seasonally through the movement and variegated quality of sunlight that enters, as well through the natural ventilation of the house.

The goal set out for the design was to create houses that are affordable and more than mere shelter for people: A dignified house that enriches the living experience of the occupants, yet contributes to wealth generation that is a necessity of our economicallymotivated contemporary life. The houses make fundamental connections to their environment that typical developer houses, which tend to be connected to the bottom line, lack. 


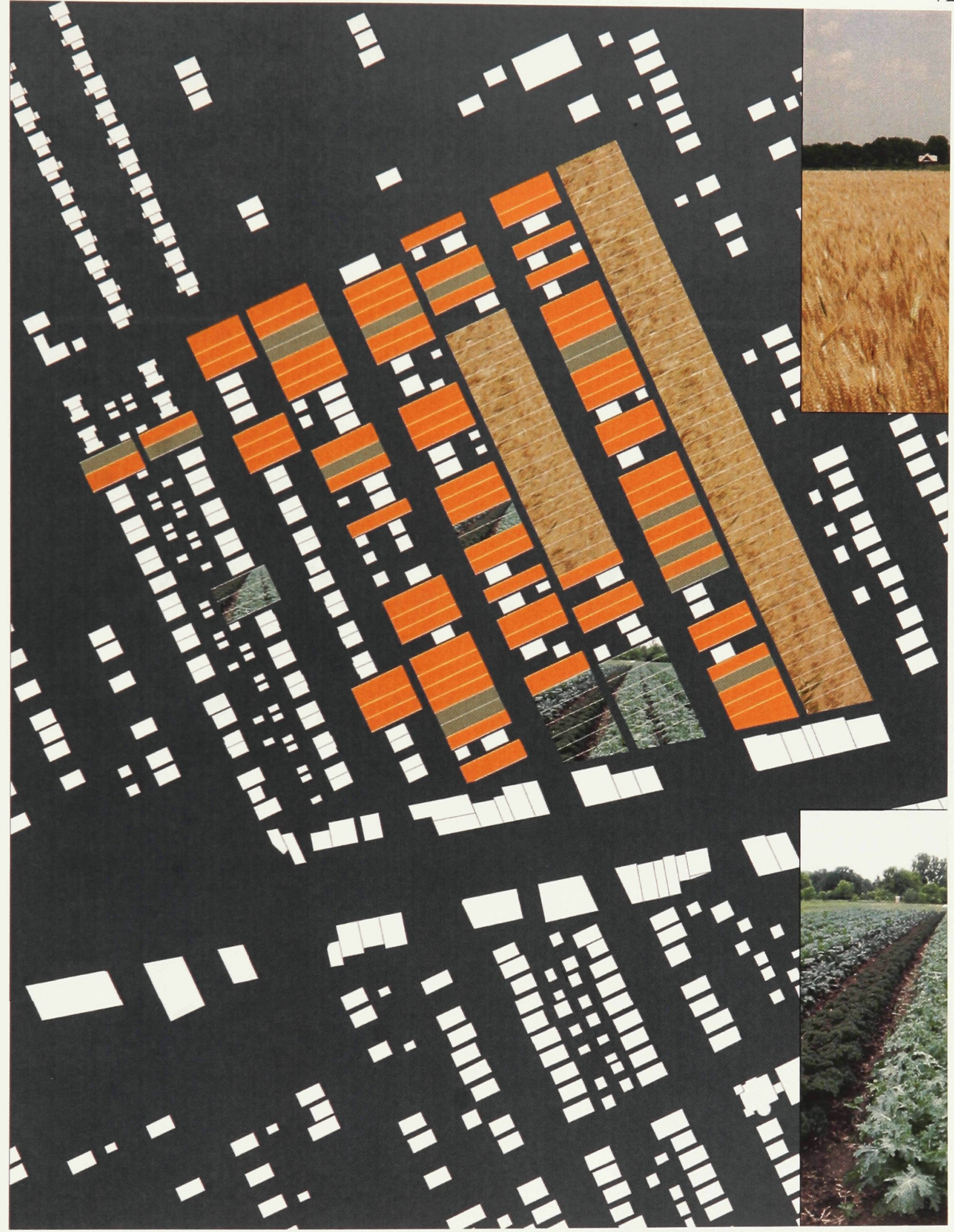

Fig. 26. Site plan showing new lots (orange), vacant lots (green) wheat, and community gardens. 


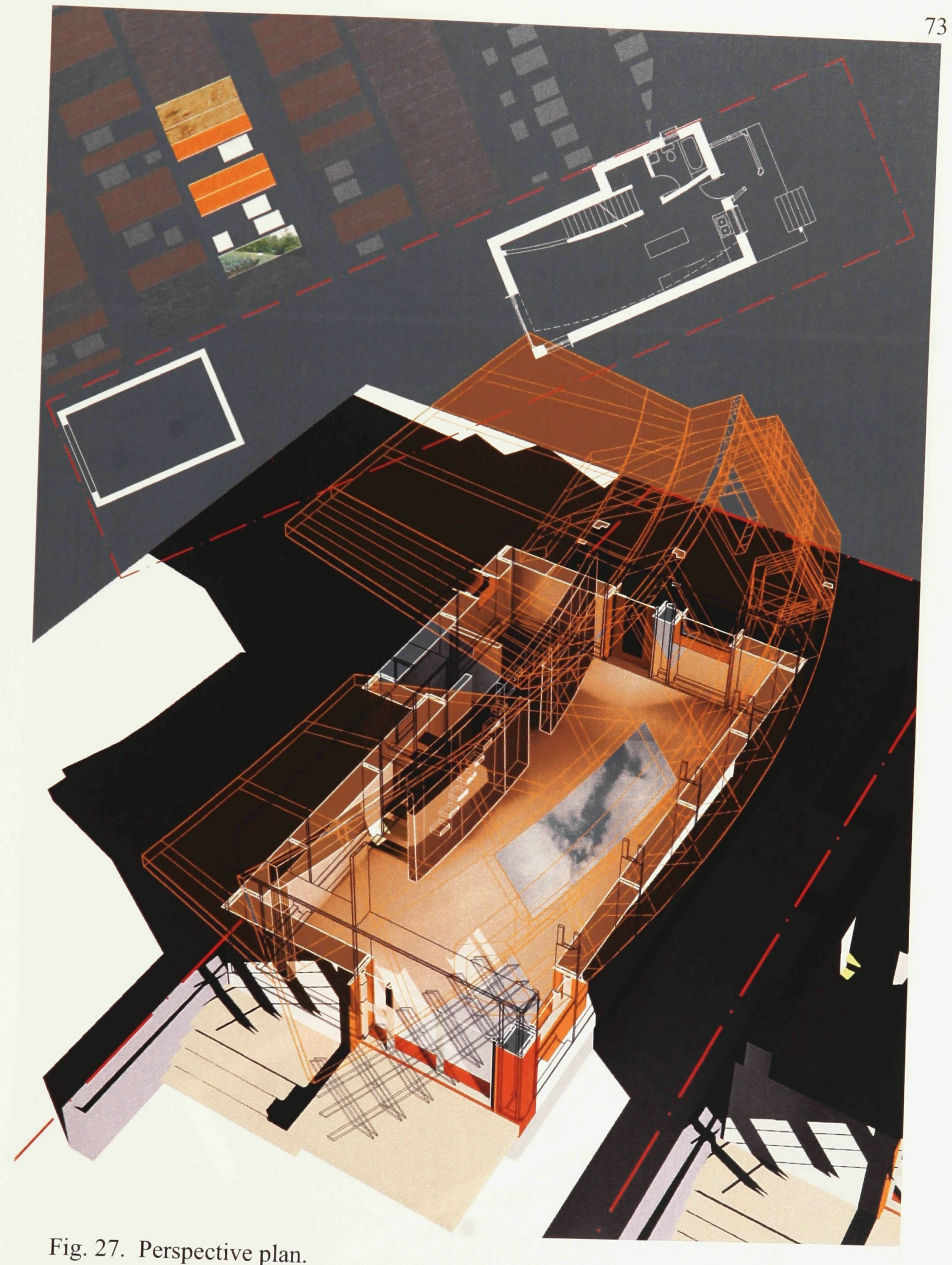




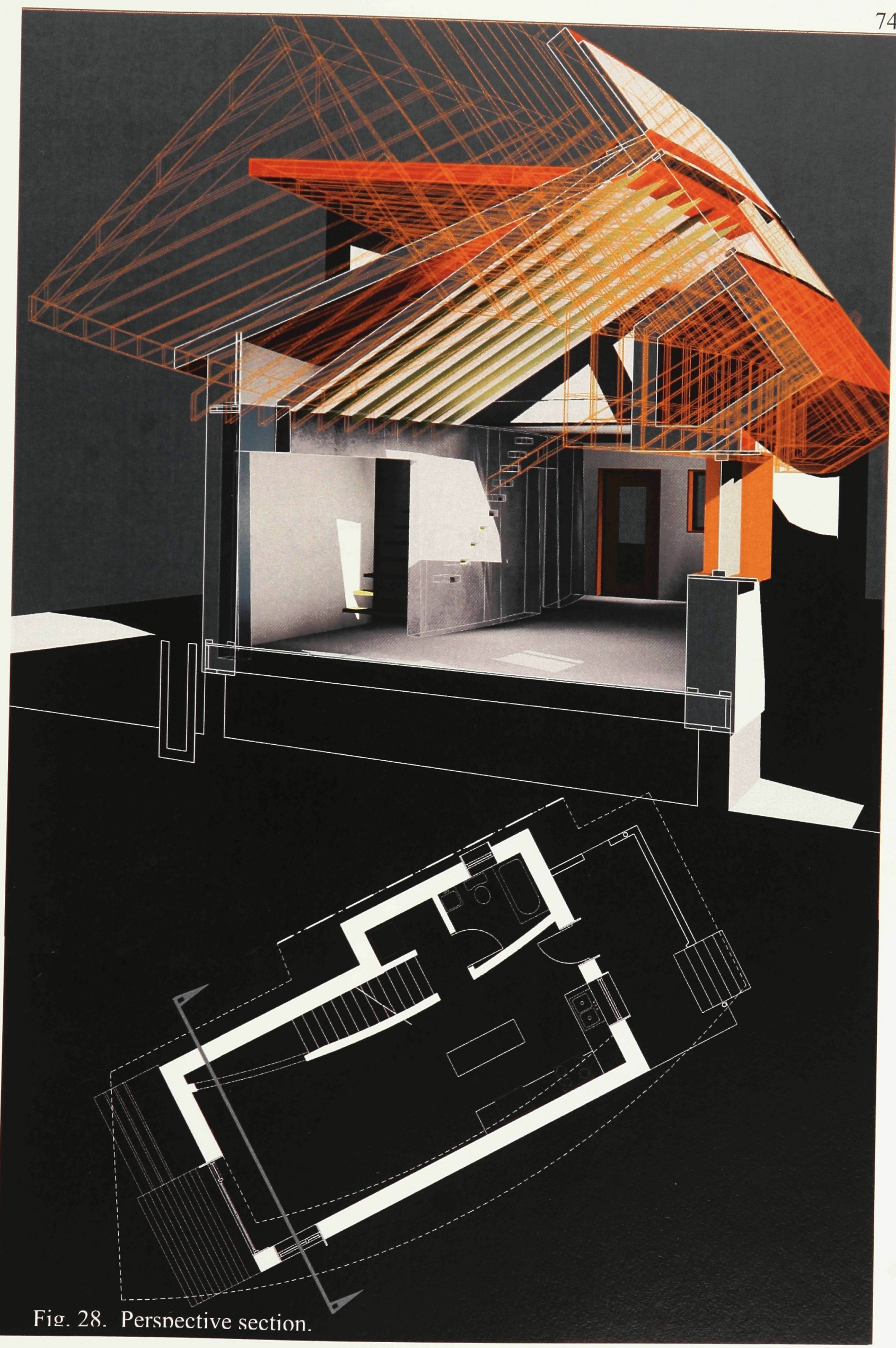




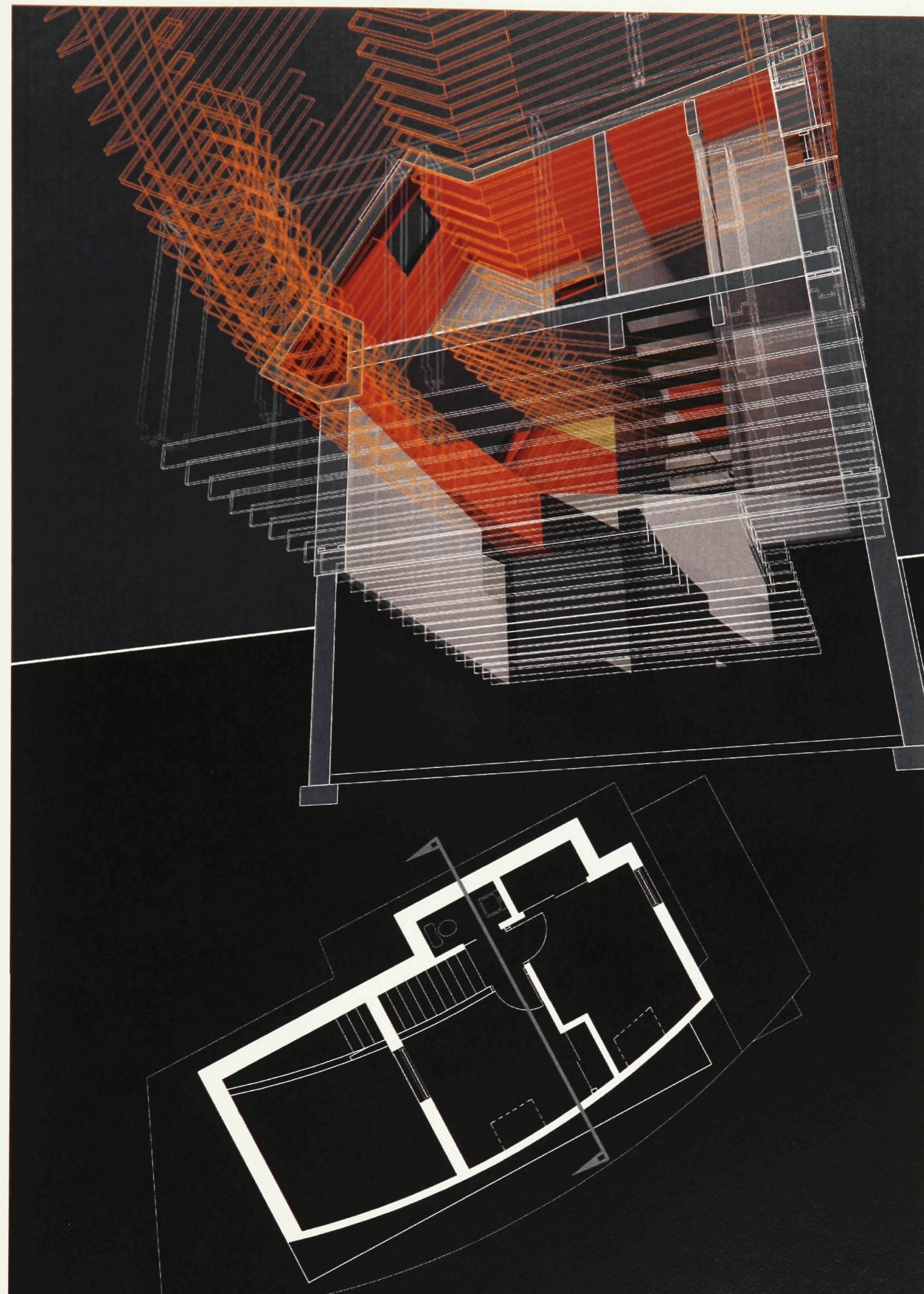

Fig. 29. Persnective section. 


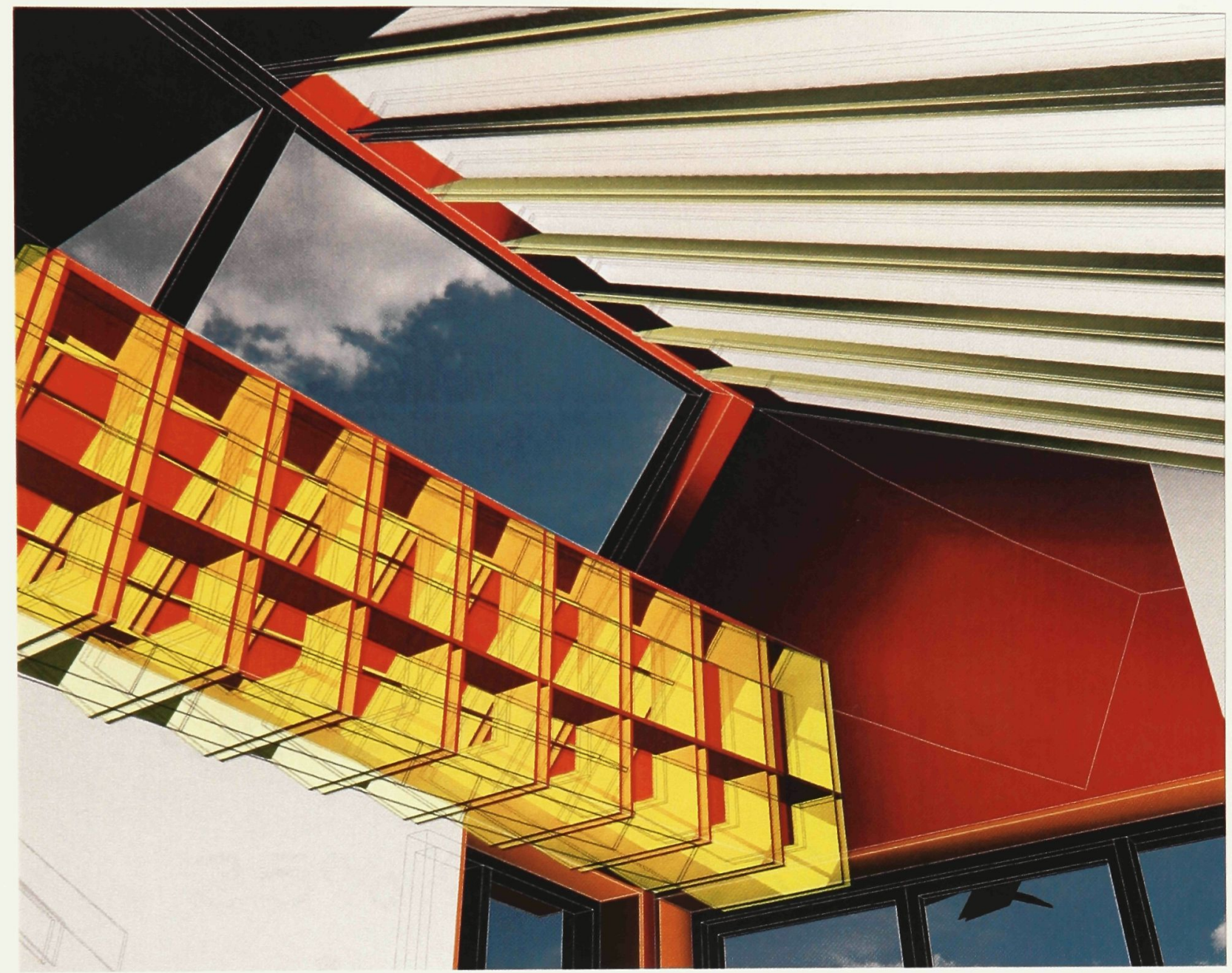

Fig. 30. Interior perspective. 


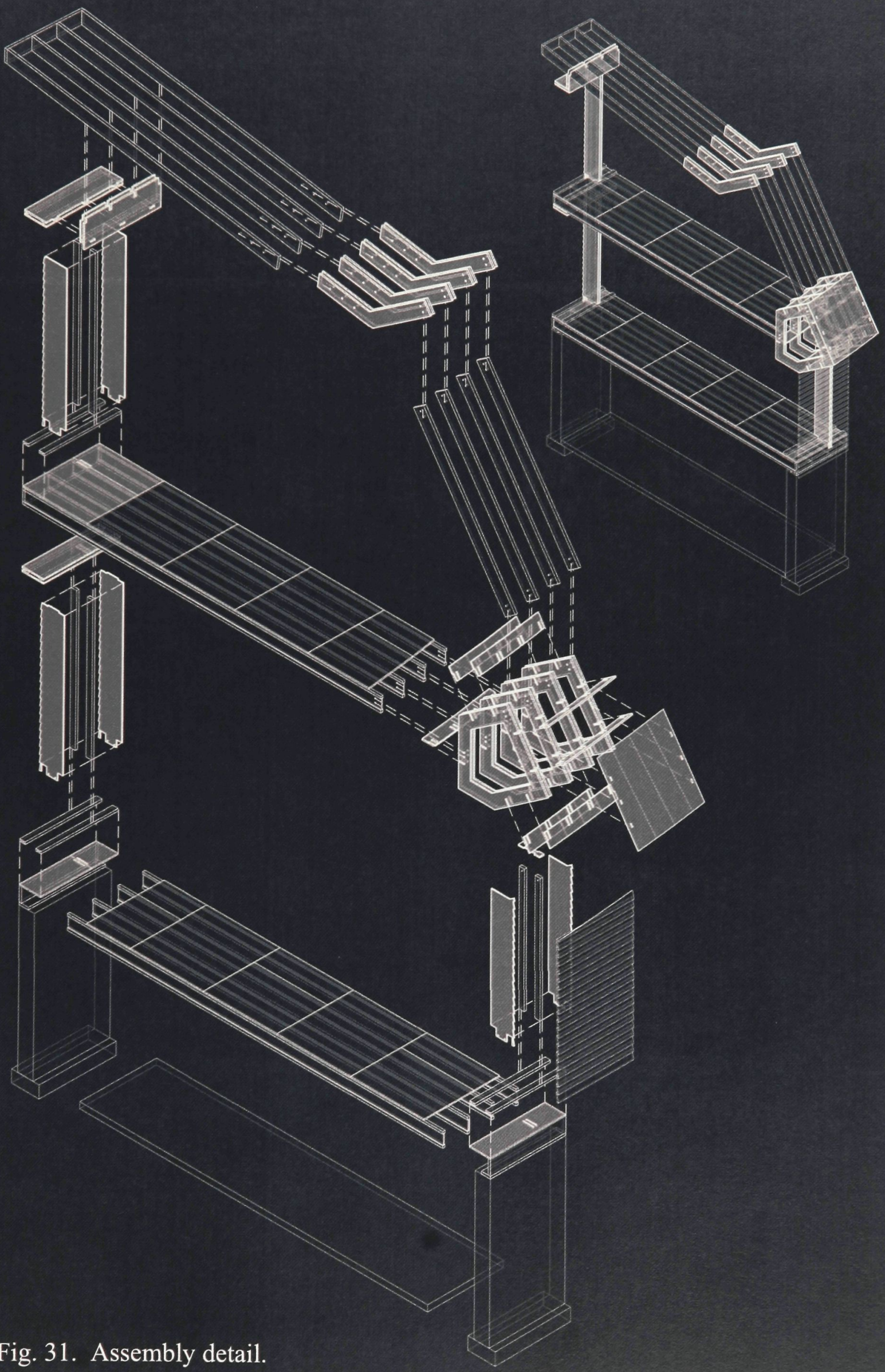




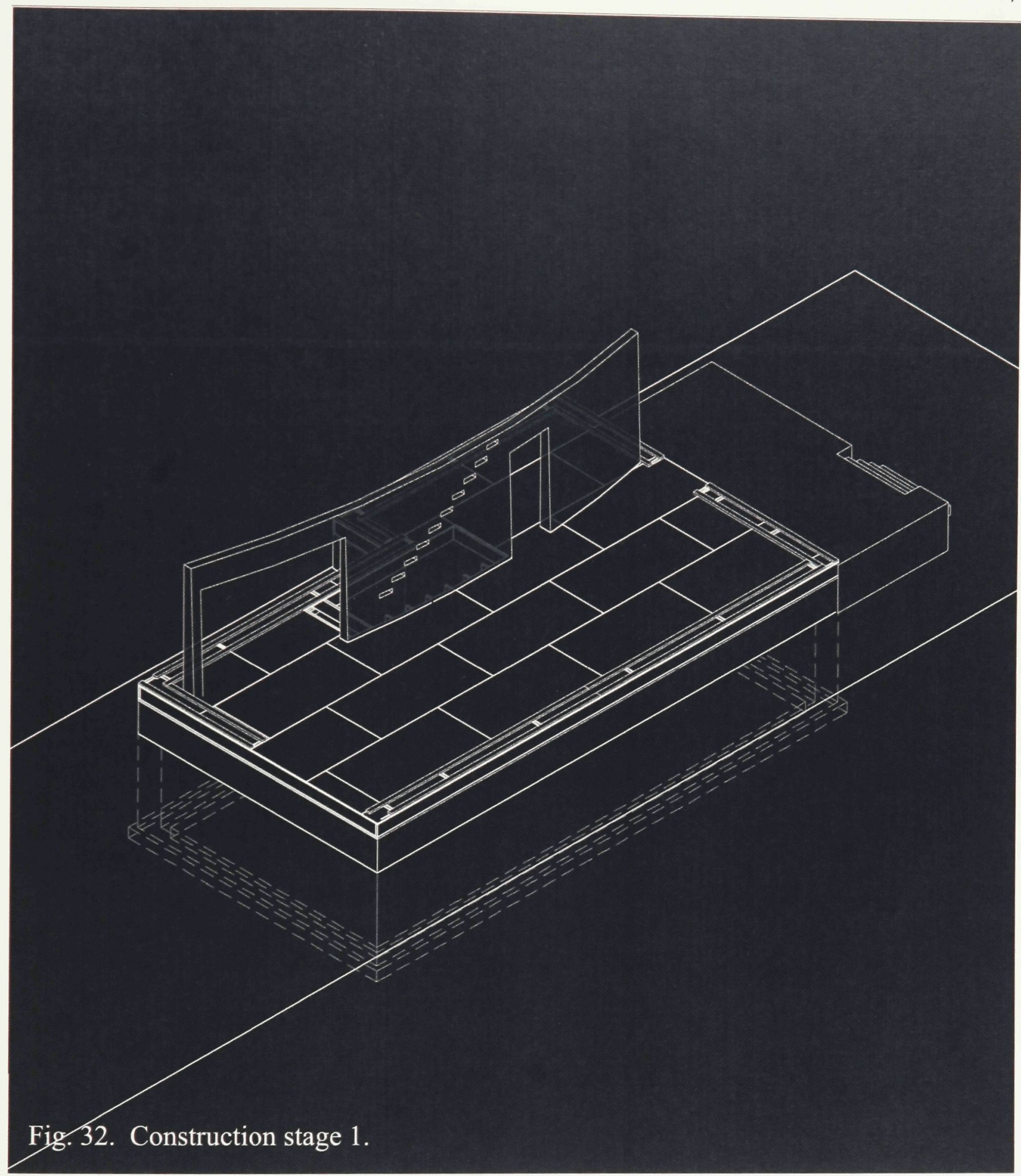




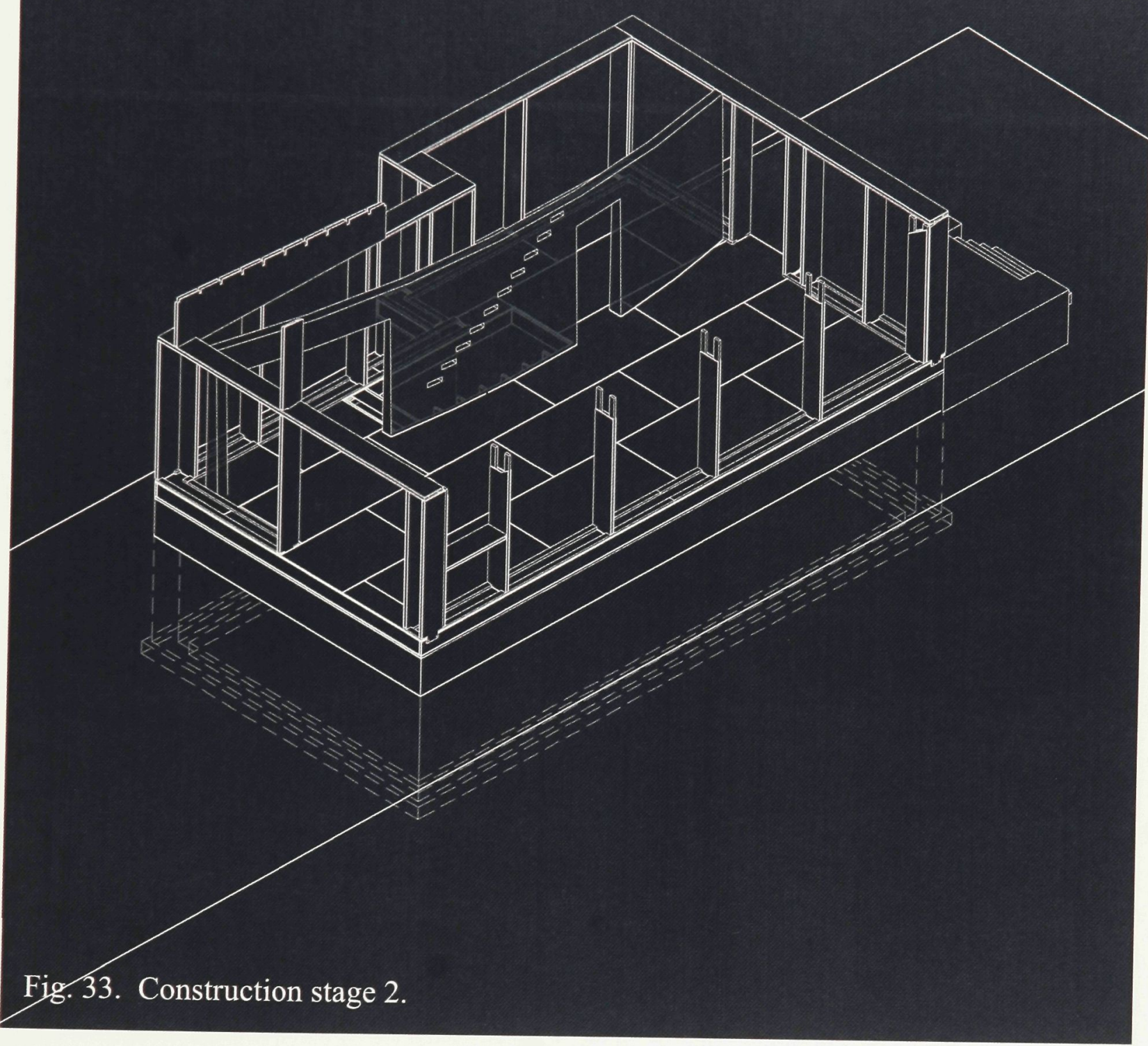




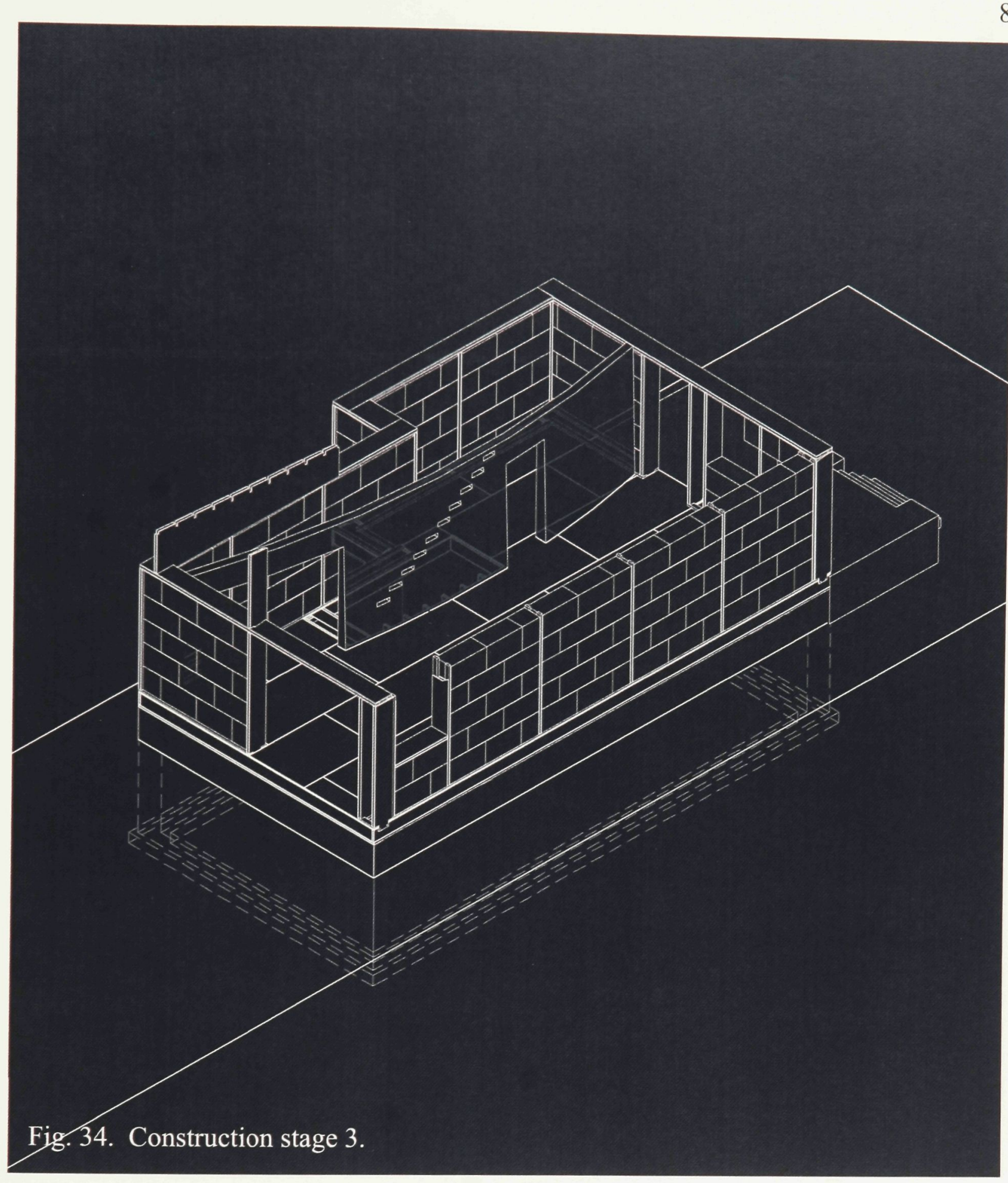




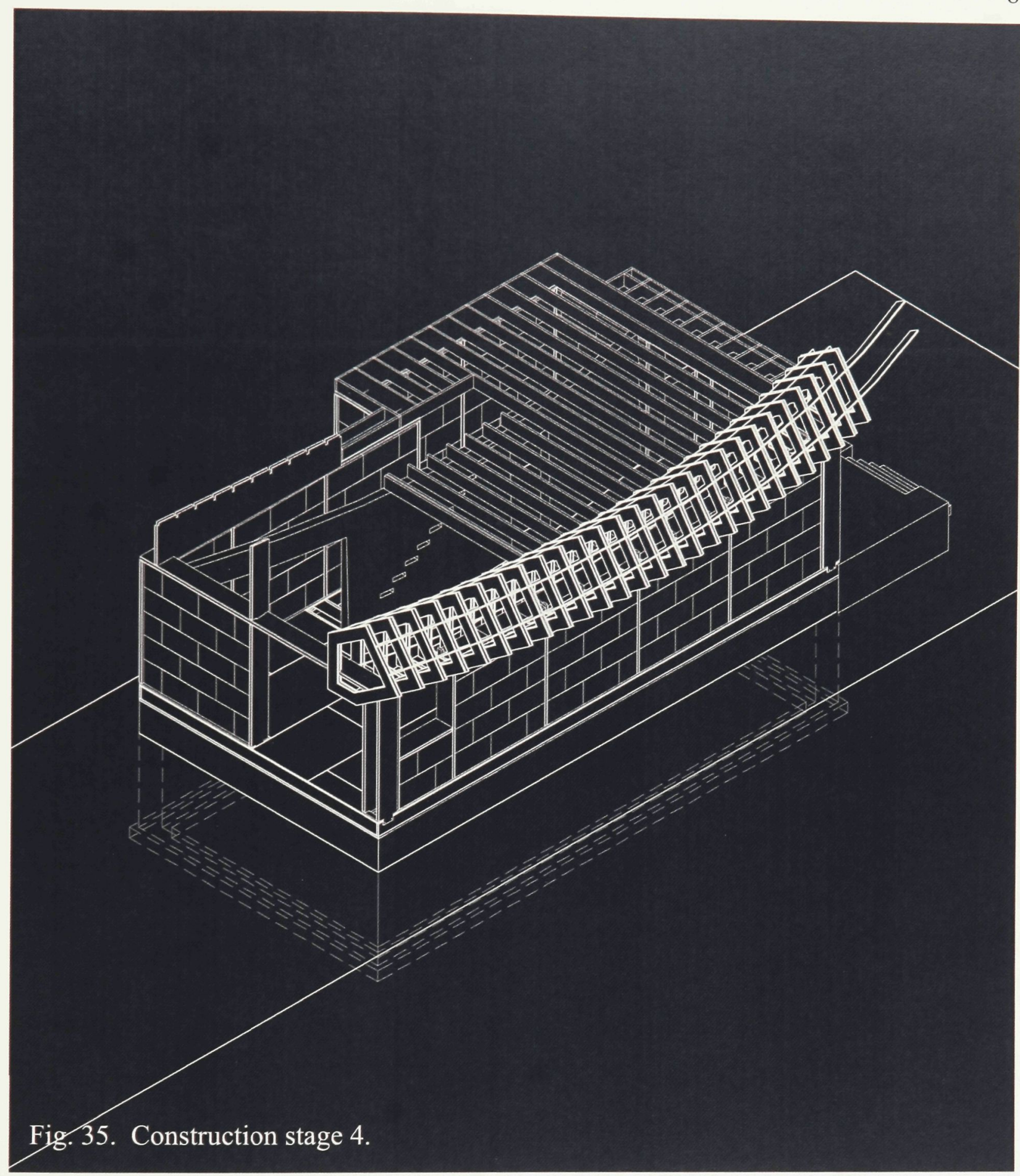




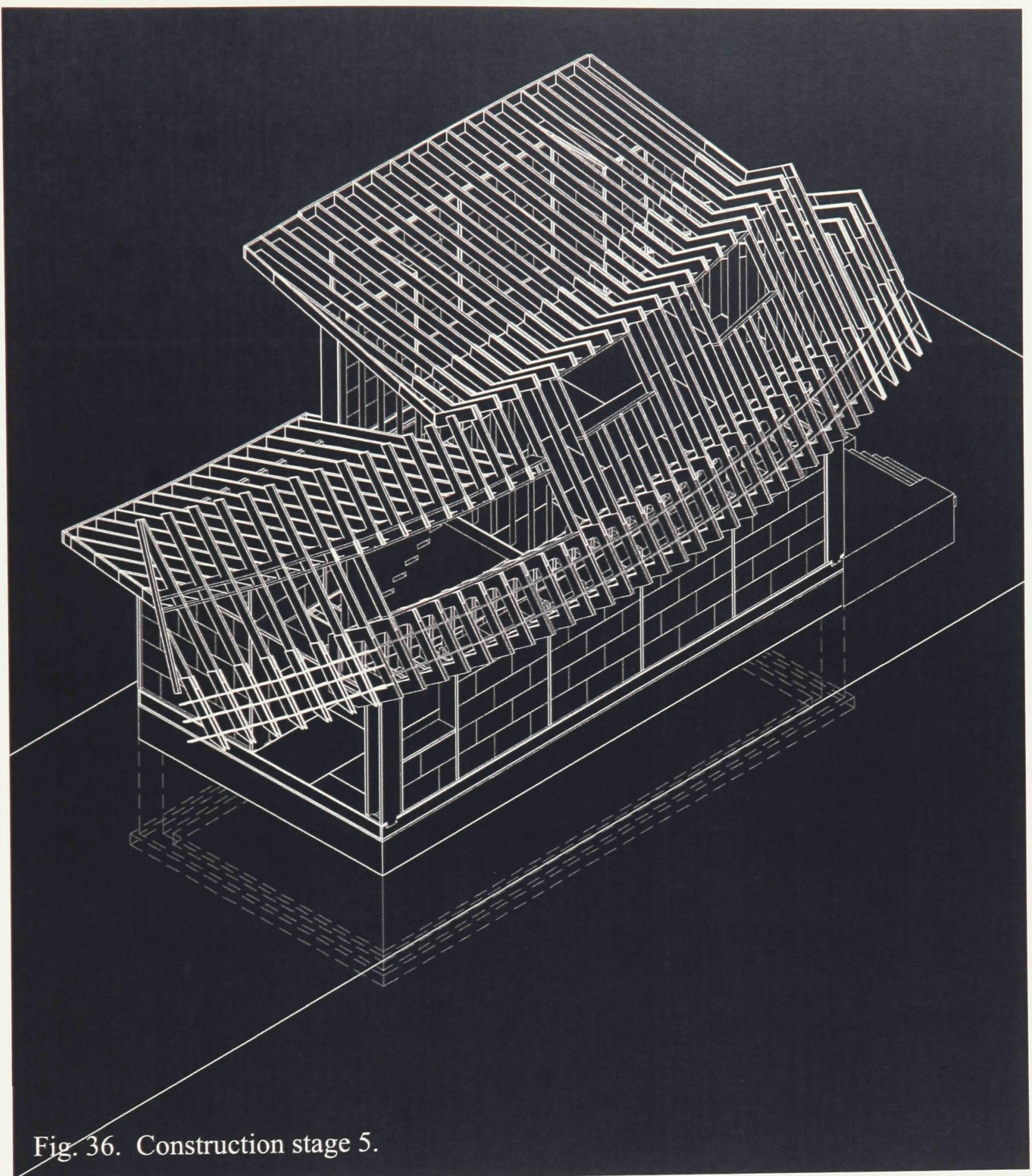




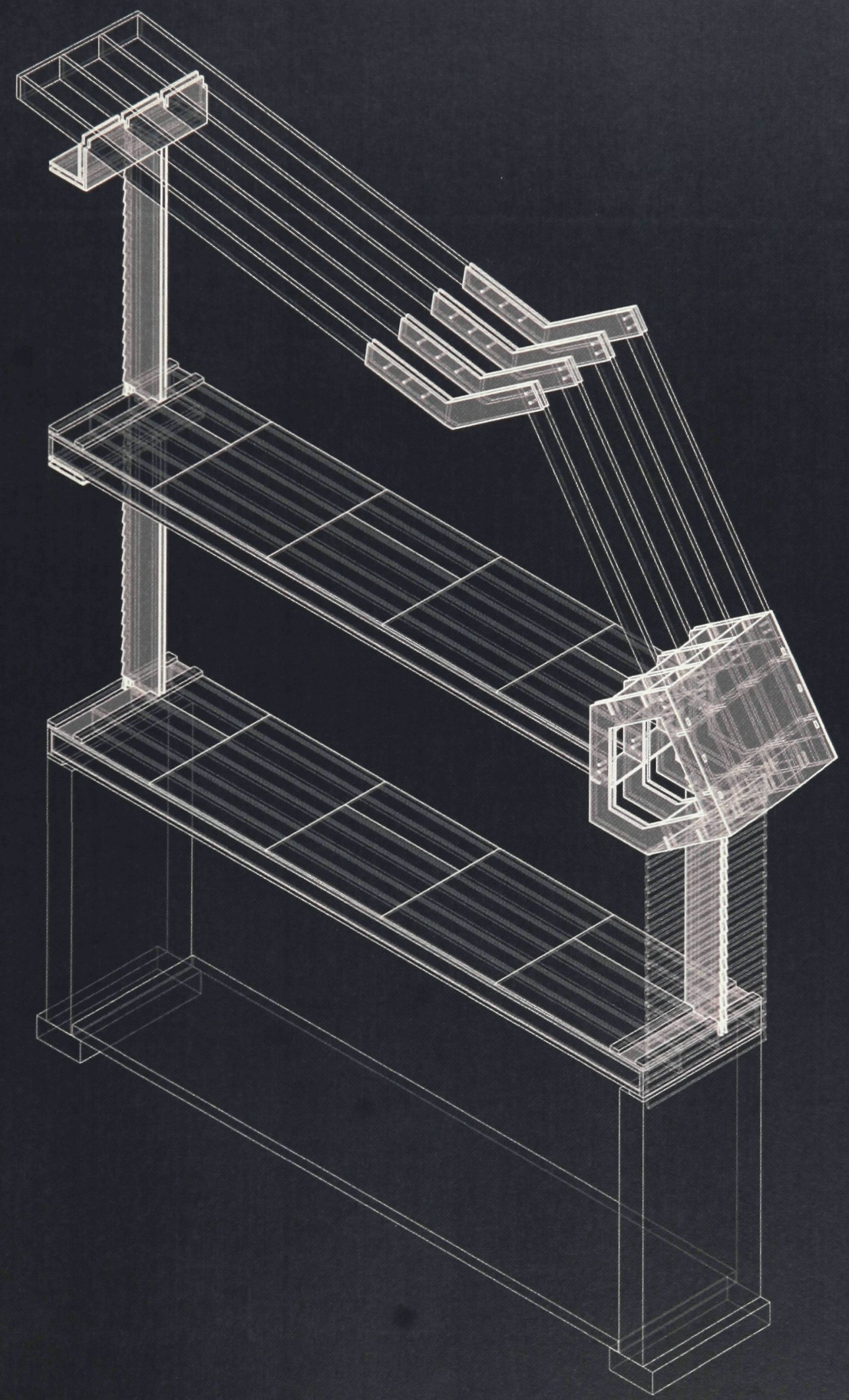

Fig. 37. Assembly detail. 
Fig. 38. Exterior perspectives.
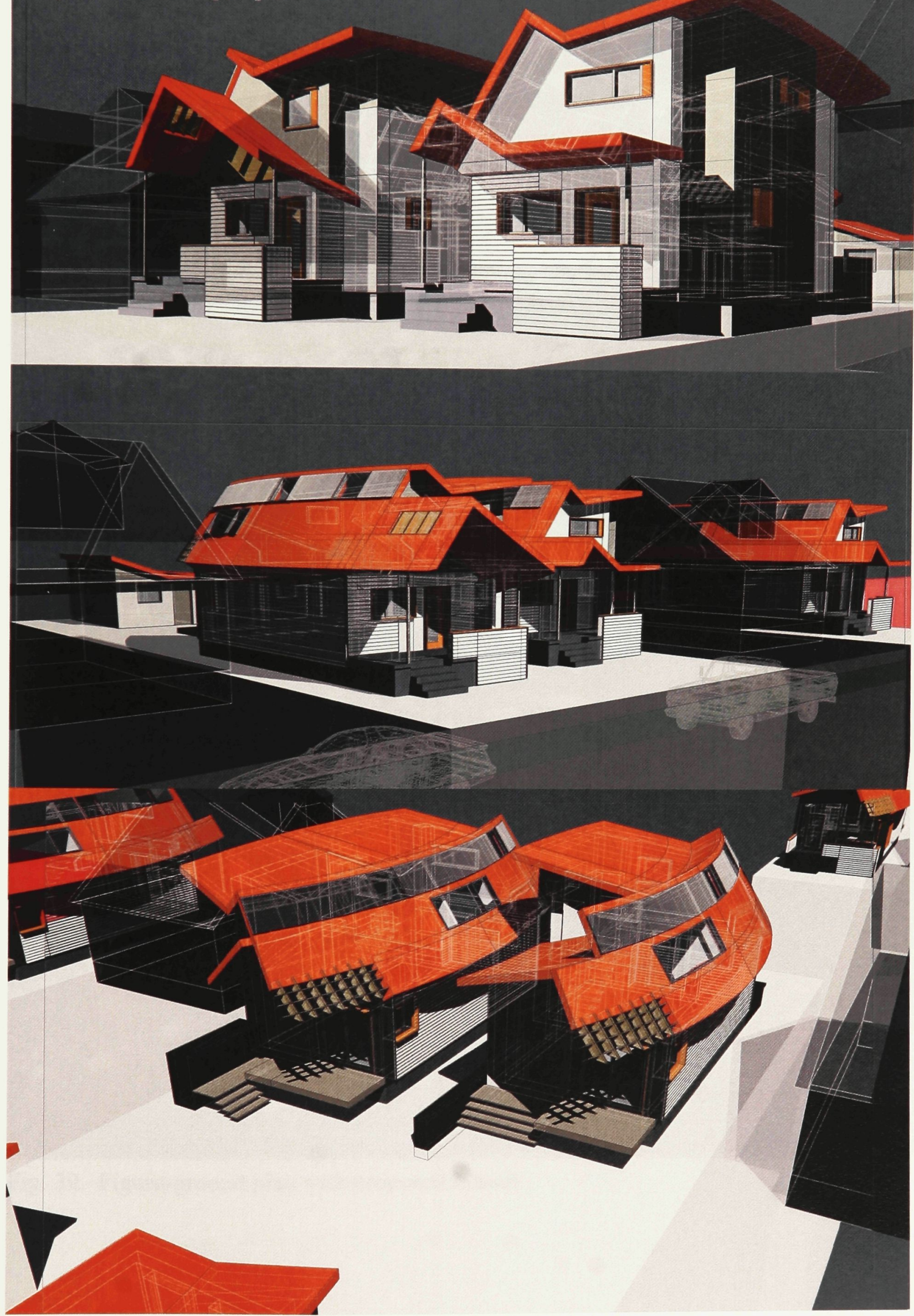


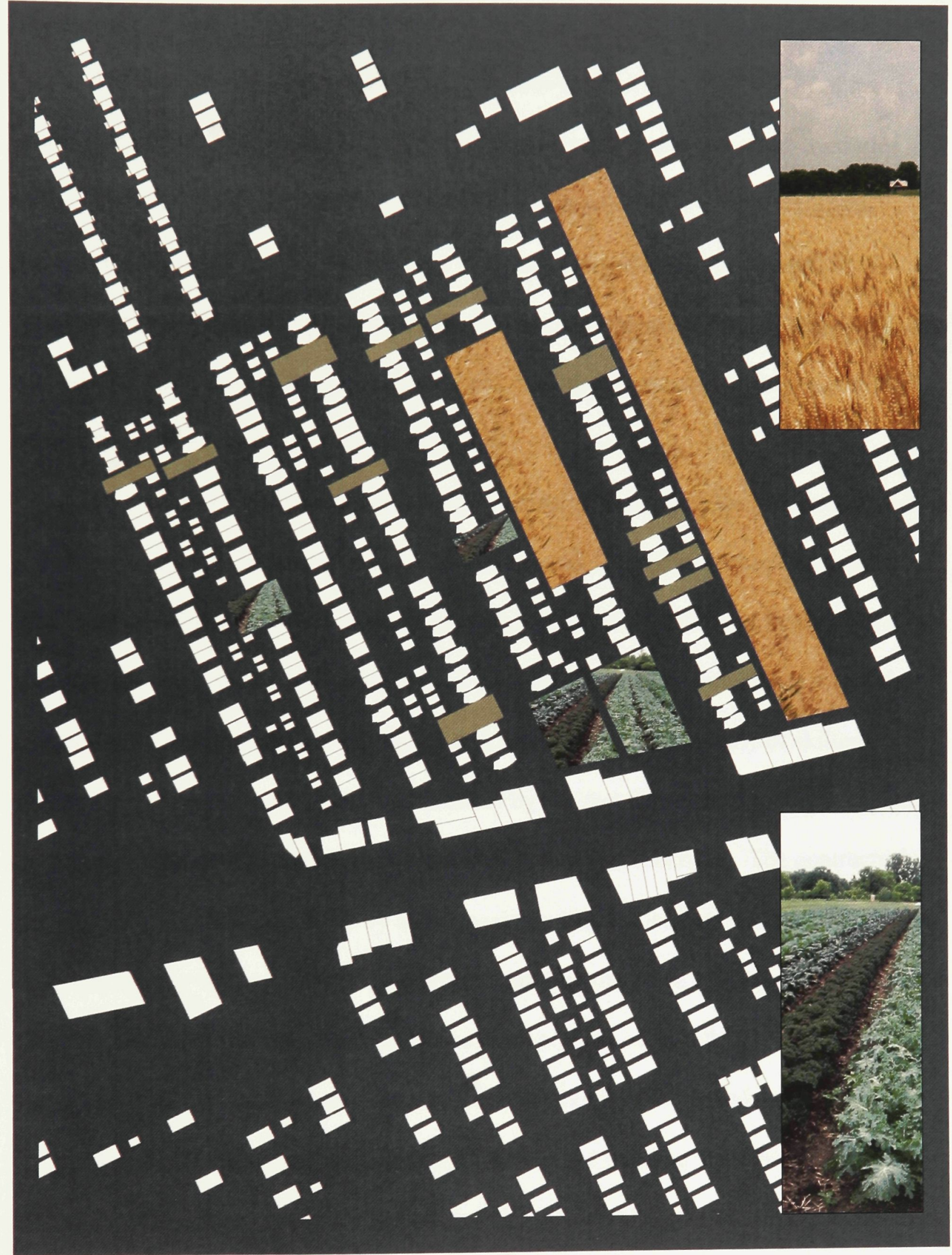

Fig. 39. Figure-ground plan with proposed houses. 


\section{Conclusion}

The capitalist system by nature has continually tried to lower the cost of the production of goods beginning with the industrial revolution and this trend continues today. There are relentless attempts to make obsolete any skilled-labour positions through the use of automated technology. This trend has affected the practice of architecture and the building culture of North America, because as Marco Frascari points out buildings are "no longer considered as long lasting cultural and social repositories", but are "viewed as economic investments" (26).

The view of buildings as economic investments has shaped the way architecture is practiced in several interrelated ways. First is the deskilling of construction workers. This trend paralleled a general trend of industry where the deskilling of factory workers was brought about by the mechanization of factories. Specialized machines meant the elimination of skilled workers and therefore lower costs. The necessity of skilled craftsmen on the construction site was reduced by the fact that architects began explicitly describing the building through detailed drawings and specifications. The contractual nature of building brought about by an increasingly litigious society dictated this explicit description prior to construction. In addition, building materials produced in mechanized factories arrived on the building site standardized and pre-shaped further reducing the necessity of skill because workers became assemblers of prefabricated parts.

Standardized building products and mechanized building was seized by modern architects. They championed the idea of rationalizing architecture through standardization, and their influence dramatically affected architecture of the twentieth century. The effects of standardization have especially influenced the production of mass 
housing by developers. They continually seek to achieve cost savings through standardized and repetitive construction, always avoiding the non-standard. The avoidance of non-standard design goes so far as to exclude non-standard or nontraditional families and households. Developers who cater to more traditional twoincome families have left many low-income families and individuals without reasonable housing. This fact is important because, due to economic restraint, the American federal government ceased to build public housing for low-income families beginning in the 1970s. Instead they gave this socially responsible task to private developers.

The exclusion of the atypical by developers again stems from the notion of building as an economic investment. Developers want a quick and guaranteed financial return upon completion of construction so building typical, standardized housing is a way to avoid risk. Risk aversion affects many aspects of building culture and has established the adversarial relationship between architect and contractor. Relationships within the current building process are organized around lines of liability rather than the most productive way to design and construct buildings. The current system of construction documentation and shop drawings are inherited from legal practices.

Combined, all of these factors leave architects in a position of lesser power. Architects are at the mercy of budgets, which is what dictated the pioneering digital work of Frank Gehry's office and allowed him to exert the kind of control necessary to realize his complex buildings. The economics of building and methods of factory production have affected the way architects practice as much as, if not more than, any movements or styles of the past 50 years. Architects must be able to operate in a world dominated by economics yet through architecture demonstrate that building is a social investment. It 
requires more innovation on the part of the architect, not for the architect to be a mere specifier of building systems.

The modern architects Walter Gropius and Le Corbusier advocated the emulation of factory production for the construction of buildings, specifically houses. Gropius even went so far as to partially found a corporation, General Panel, only to find that mass production meant design prerogatives were trumped by factory production and business concerns. Despite the failures of the many prefabricated home attempts, the dream of mass producing large parts or whole homes still persists. Rather than imitating the automobile industry, which was the example of the twentieth century, today there is a push to have the construction industry emulate the ship building and aerospace industry. Unless the architect is able to play an integral role, it will only further erode the position of power.

The reality of site-based construction is that more customization means more labour, and therefore higher cost. Technologically, architects can become more involved through digital fabrication, detailing at a more fundamental level as did William Massie. Technological innovation may be the easy part. Gehry's office has found both cultural and legal resistance to changing the construction system as they push the traditional boundaries of architects, contractors, and fabricators. If the building culture is going to be reorganized for the better, architects need to seek change actively, perhaps taking on more risk.

Accompanying a role of greater influence in the construction of buildings should be an ethical and socially responsible position. An increasingly privatized world means that economics will influence more facets of society, not fewer. Architects are neither 
guardians of the downtrodden nor social engineers, but when social causes related to architecture like affordable housing are being forgotten because of economic motivation, architects need to act. The reason for this, as Robert Gutman points out, is that it is "an appropriate concern for a profession as distinguished from a business occupation" (58).

The design proposition for affordable housing on Detroit's eastside demonstrates that architects can be in a position to design housing that both enriches lives and is economically affordable. Despite the fact that developers build housing outside of the influence of architects, architects can indeed play a role in housing. Through the use of digital fabrication and therefore a more involved role in fabrication and construction, architects can practice from a renewed position of social responsibility put forth by modernist architects. 


\section{Works Cited}

Bauman, John F. et al. From Tenements to the Taylor Homes: In Search of an Urban Housing Policy in Twentieth-Century America. University Park: The Pennsylvania State University Press, 2000.

Biggs, Lindy J. The Rational Factory. Baltimore: Johns Hopkins University Press, 1996.

Callicott, Nick. Computer-Aided Manufacture in Architecture: The Pursuit of Novelty. Oxford: Architectural Press, 2001.

"CATIA at Frank O. Gehry \& Associates, Inc.," $\mathrm{http}: / / \mathrm{www} . d t e . c o . u k / \mathrm{html} /$ case_frank_gehry.htm.

Cocke, Andrew. "The Business of Complex Curves" Architecture Dec. 2002: 54+.

Davis, Howard. The Culture of Building. Oxford: Oxford University Press, 1999.

Forrest, Ray \& Alan Murie. Housing and Family Wealth: Comparative International Perspectives. London: Routledge, 1995

Frascari, Marco. "The Tell-the-Tale detail." Via No.7 1984: 22-37.

Friedman, Mildred et al. Gehry Talks: Architecture + Process. New York: Universe Publishing, 2002.

Glymph, Jim. "Evolution of the Digital Design Process." Architecture in the Digital Age: Design and Manufacturing. Ed. Branco Kolarevic. New York: Spon Press, 2003. 101-120.

Gold, . The Experience of Modernism: Modern Architects and the Future City 19281953. London: E\&FN Spon, 1997.

Gropius, Walter. Apollo in the Democracy: The Cultural Obligation of the Architect. New York: McGraw, 1968.

Gropius, Walter. The New Architecture and the Bauhaus. Cambridge: MIT Press, 1965.

Gutman, Robert. The Design of American Housing: A Reappraisal of the Architect's Role. New York: Publishing Center for Cultural Resources, 1985.

Herbert, Gilbert. The Dream of the Factory-Made House. Cambridge: MIT Press, 1984. 
Hounshell, David A. From the American System to Mass Production 1800-1932. Baltimore: Johns Hopkins University Press, 1984.

Kolarevic, Branko. Architecture in the Digital Age: Design and Manufacturing. New York: Spon Press, 2003.

Kushner, James A. Apartheid in America: An Historical and Legal Analysis of Contemporary Racial Residential Segregation in the United States. Frederick: Associated Faculty Press, 1980.

Le Corbusier. Towards a New Architecture. Trans. Frederick Etchell. London: Butterworth Architecture, 1927 (1989 edition).

Massie, William. "Remaking in a Post-Processed Culture." Versioning: Evolutionary Techniques in Architecture. West Sussex: Wiley-Academy, 2002.

Mitchell, William J. "Roll Over Euclid: How Frank Gehry Designs and Builds." Frank Gehry, Architect. Ed. Ragheb, Fiona J. New York: Guggenheim Museum Publications, 2001. 352-363.

Sugrue, Thomas. The Origins of the Urban Crisis: Race and Inequality in Postwar Detroit. Princeton: Princeton University Press, 1996.

Reintjes, Frances J. Numerical Control: Making a New Technology. New York: Oxford University Press, 1991.

Retsinas, Nicolas P. \& Eric S Belsky. Low-Income Homeownership: Examining the Unexamined Goal. Washington: The Brookings Institution, 2002.

Rose, Judy. "East-Side Story:Ambitious plans les new homes blossom slowly while healthy ones are preserved." Detroit Free Press. May 4, 2003 http://www.freep.com/realestate/renews/east4_20030504.htm.

Rose, Judy. "Far Eastside Project: Recipe for revival." Detroit Free Press. May 11, 2003 $<\mathrm{http}: / /$ www.freep.com/realestate/renews/east11_20030511.htm>

United States. Census Bureau. "Summary File 1 (SF 1)", 2000.

Zellner, Peter. Hybrid space : New Forms in Digital Architecture. New York: Rizzoli, 1999. 


\section{Appendix}

\section{CNC Router Experimentation}

In connection with the design proposition a brief exploration was undertaken to test the concept of producing physical artifacts directly from virtual three-dimensional models. In addition the exploration served as a simple familiarization with the technology, both hardware and software, of $\mathrm{CNC}$ routing.

The first experiment utilized three-dimensional contouring of rigid insulation. A 3-axis router was used to mill a negative mold for casting plaster. Although the fluid geometry that can be created by contouring is perhaps more compelling than simple twodimensional cutting, it is time consuming. In order to create a smooth surface the path of the tool bit must overlap its previous path substantially. This means the router requires many more passes over the material being shaped than simple cutting.

The second experiment, although still employing a 3-axis router, was restricted to two dimensional cutting. This method is much quicker, and therefore less costly. A 4 x 8 plywood sheet was cut to produce the components of a "wall". Inherent in this test was that the parts would be non-standard (each varying from the next) and that the geometry of the wall would be complex enough to be beyond the reasonable descriptive ability of orthogonal drawing. In this case, the wall curves in both plan and section. The wall was put together without any fasteners, only friction-fit joints of the plywood itself. A small aside was to also test the integration of standardized $2 \times 4$ lumber with the $\mathrm{CNC}$ cut plywood. 


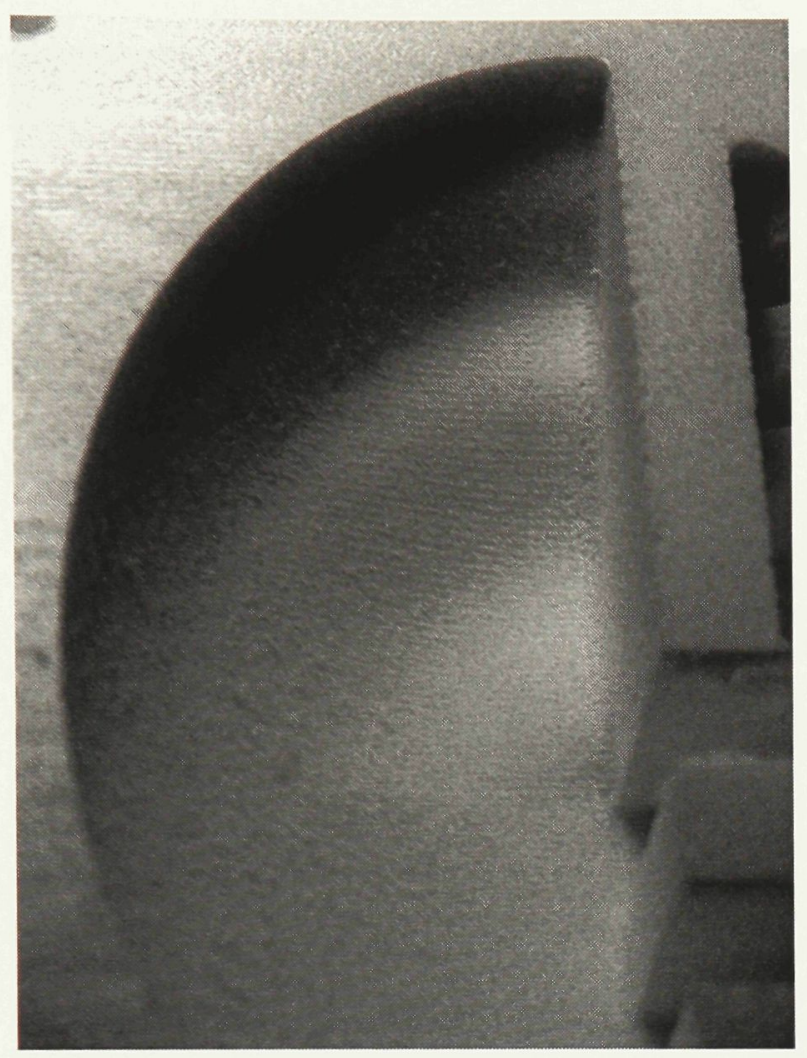

Fig. 40. Contoured rigid insulation.

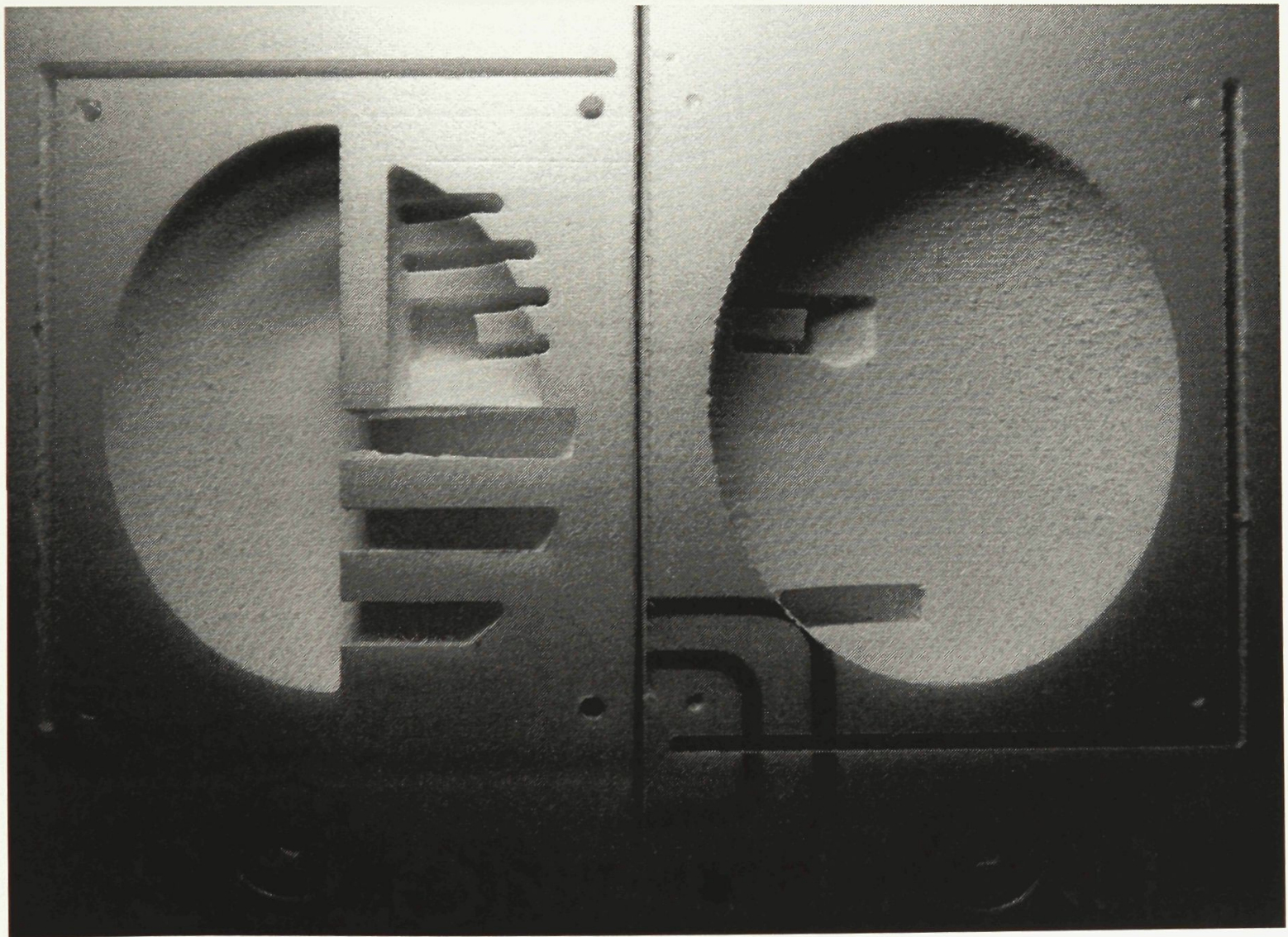

Fig. 41. Contoured rigid insulation. 


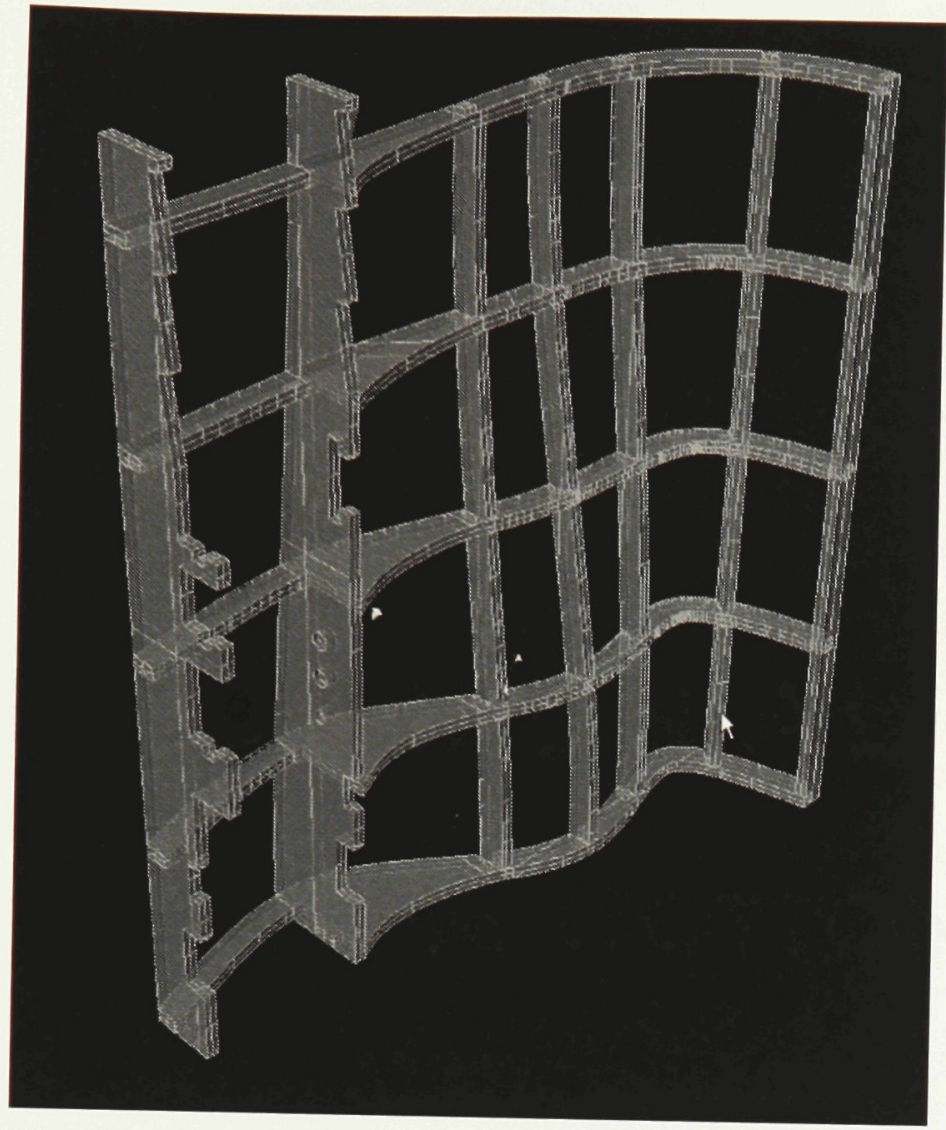

Fig. 42. Digital model of "wall".

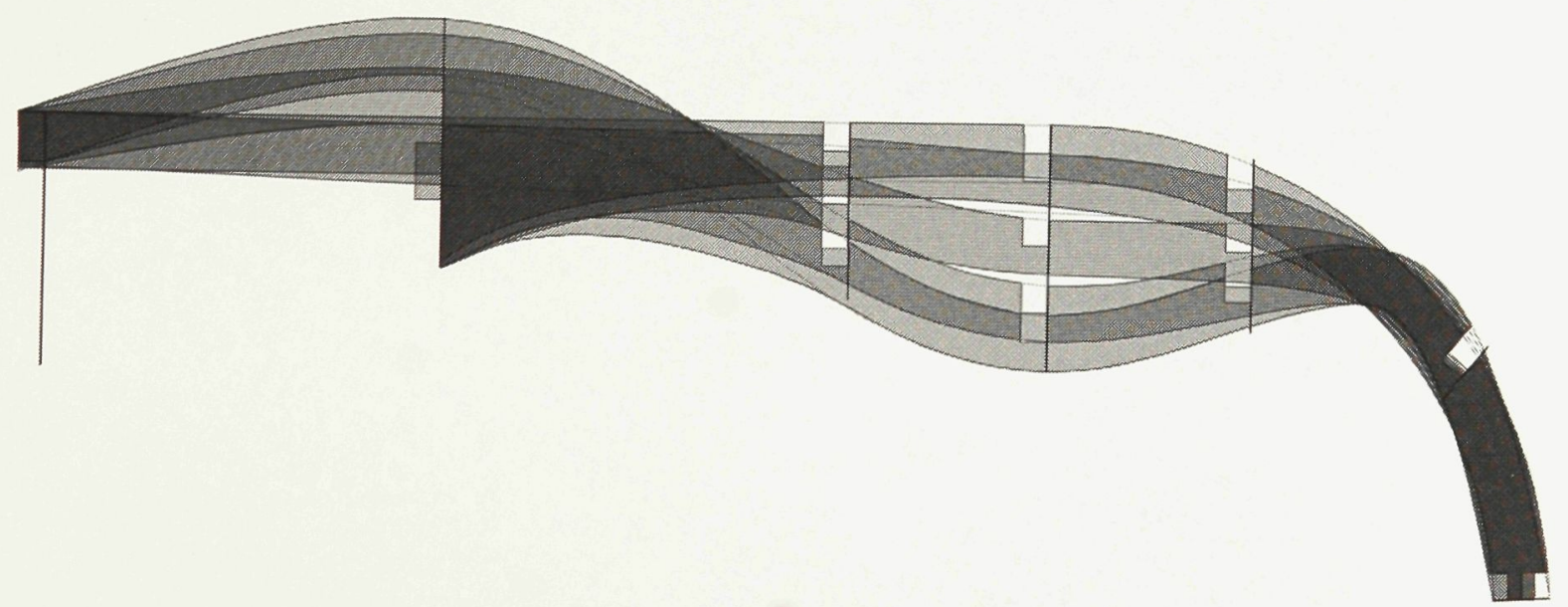

Fig. 43. Plan of "wall". 


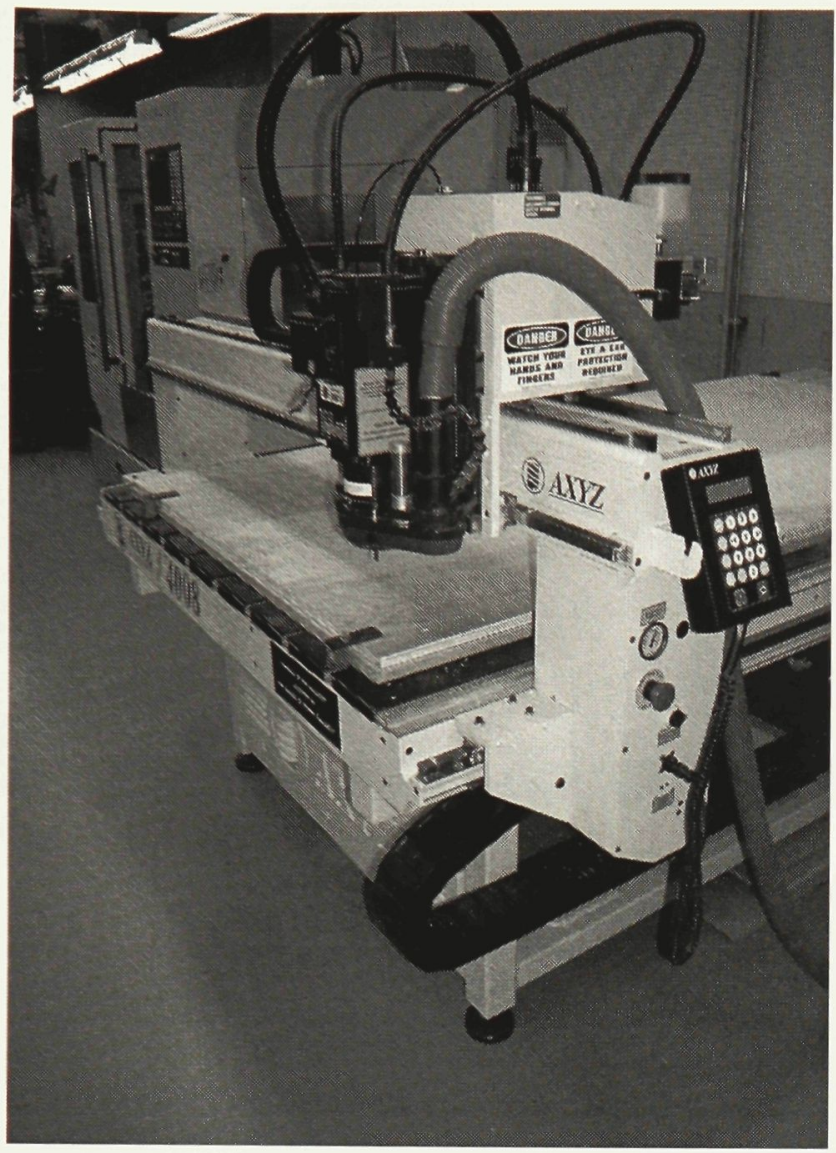

Fig. 44. Three-axis CNC router.

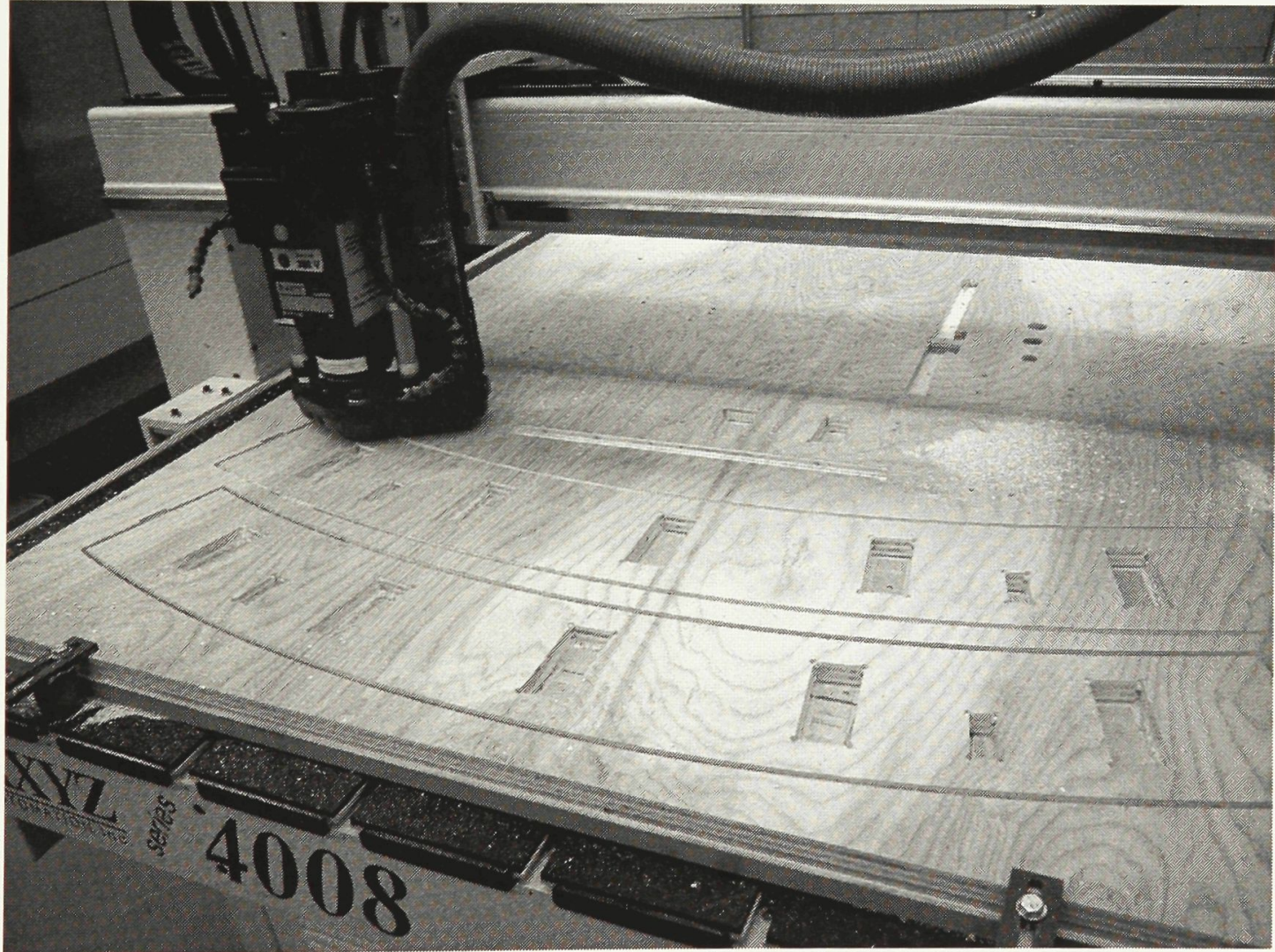

Fig. 45. Three-axis CNC router cutting plywood. 


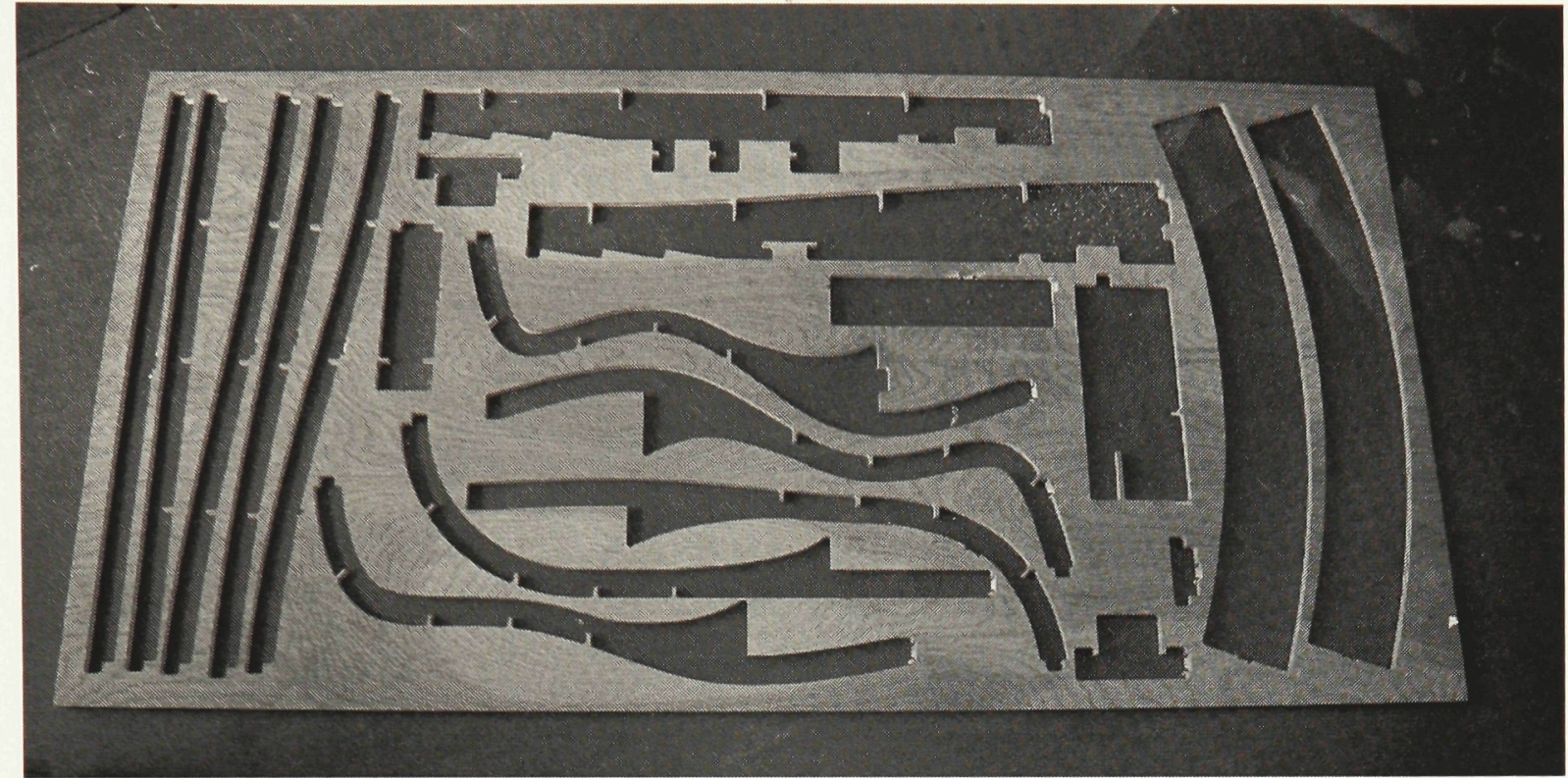

Fig. 46. Leftover plywood

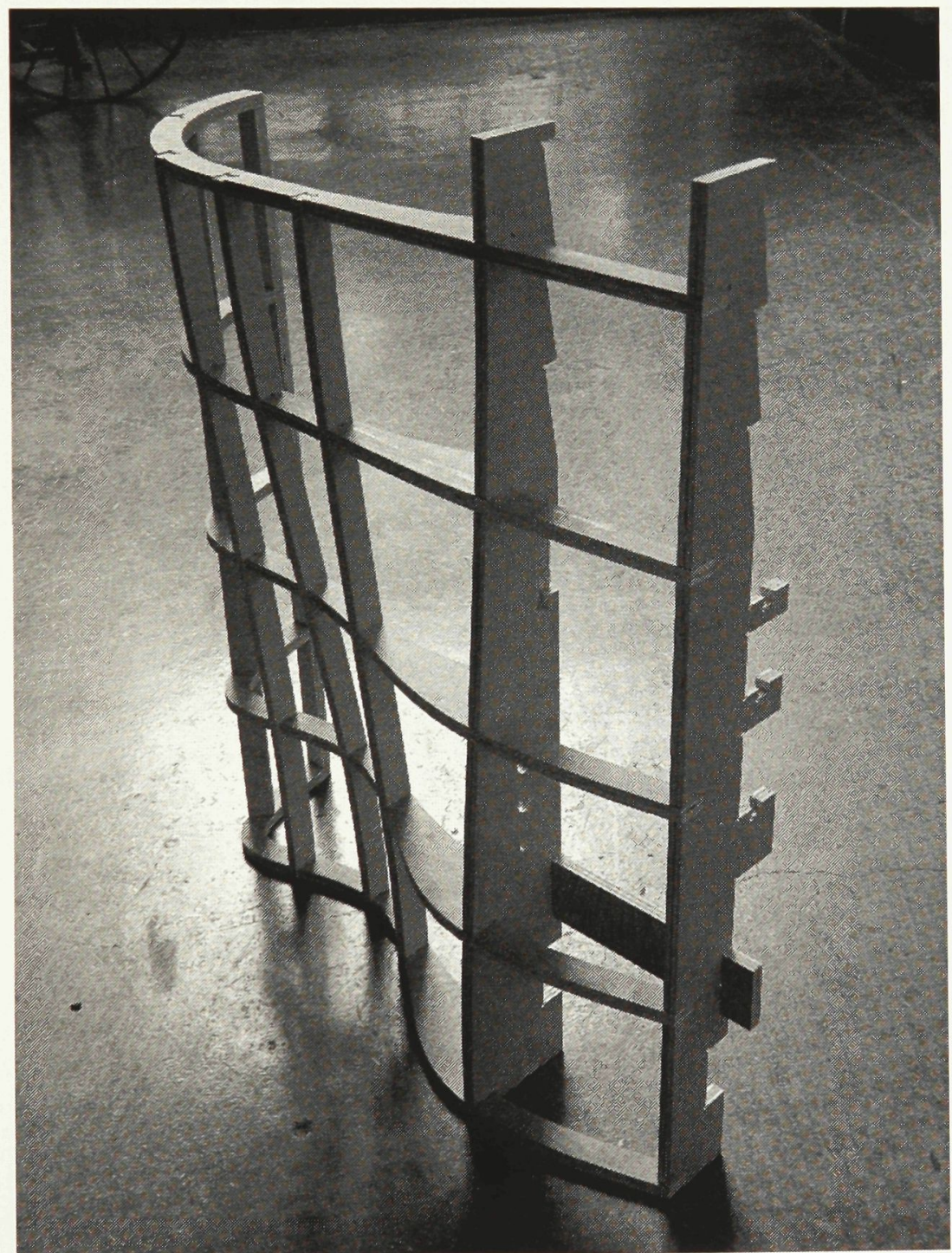

Fig. 47. Assembled wall. 